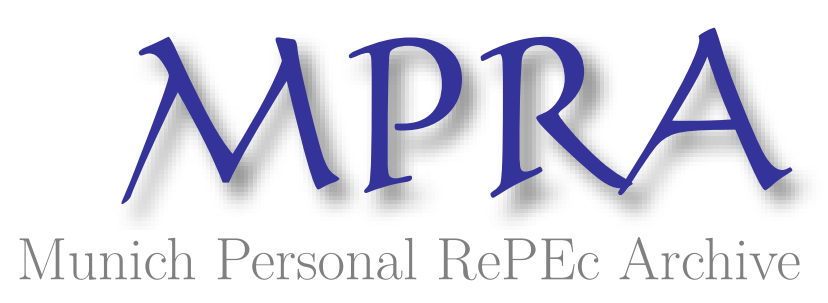

\title{
Who cares about Director Independence?
}

Paolo, Santella and Carlo, Drago and Giulia, Paone

14 March 2007

Online at https://mpra.ub.uni-muenchen.de/2288/

MPRA Paper No. 2288, posted 20 Mar 2007 UTC 


\title{
Who Cares About Director Independence?1
}

\author{
March 2007 \\ Paolo Santella*, Carlo Drago**, Giulia Paone***
}

\begin{abstract}
In this article we have expanded the analysis of the new dataset we created in Santella, Paone, Drago (2005) which analysed and quantified corporate disclosure on directors formally identified as independent by the forty Italian Blue Chips. We find here a general low level of compliance with independence requirements for both financial and non-financial companies, particularly with regard to the two key independence criteria of not having too many concurring commitments and not having business relationships with the company or an associated company. We also find that financial companies show a lower level of compliance than non-financial ones and are connected with each other and with a few non-financial companies through networks of cross-directorships: two directors (one independent and one executive) who also sit at the same time on another company board. Finally, those non-financial companies that have a relatively fragmented shareholder structure tend to be characterised by higher levels of compliance and disclosure (but not always by lower levels of not compliance) than tightly-controlled non-financial companies, presumably because of sensitivity to a larger pool of small shareholders. Peculiarly, financial companies with fragmented shareholder structure tend to be characterised by low disclosure levels, although such companies are also subject to strong financial supervision.
\end{abstract}

Keywords: corporate governance, independent directors, interlocking directorships, empirical legal studies.

* Bank of Italy and European Commission.paolo.santella@ec.europa.eu

** University of Naples "Federico II". c.drago@mclink.it

*** Visiting Scholar at the Center for Corporate Governance, Tuck School of Business at Dartmouth College, NH, USA. giulia.paone@dartmouth.edu

\footnotetext{
${ }^{1}$ The views expressed in the article represent exclusively the positions of the authors and do not involve in any way the responsibility of the Bank of Italy or the European Commission. We thank Enrico Baffi and Marcello Bianchi for the advice provided during the preparation of the article. We are indebted to Espen Eckbo and Alan Schwartz for their very helpful suggestions. We also thank Mariagrazia Albano, Livia Aliberti, Magda Bianco, Stefano Cappiello, Giuseppe Carriero, Silvia Giacomelli, Luca Enriques, Luigi Franzoni, Hans Hirt, Domenico Irace, Grant Kirckpatrick, Alfonso Papa Malatesta, Gianmaria Marano, Joe Mc Carey, Colin Melvin, Emiliano Miluzzo, Valentina Sansonetti, Bruna Szego, Elena Tedesco, Dominique Thienpont, Gustavo Visentini, an anonymous referee, and all the participants to a seminar at the Bank of Italy, Law and Economics Department, on 14 December 2005 for their comments and suggestions. We also thank the participants to the Second Annual Conference of the Italian Society of Law and Economics, Roma 20 October 2006; to the Seminar in Financial Law and Economics held in Bologna on 29 January 2006; and to the seminar Shareholders' Rights \& Independent Directors, Hermes Pensions Management Limited, London, 12 December 2005. Finally, we thank Andrea Polo for his advice and support. Of course, the authors are the sole responsible for the opinions expressed.
} 


\section{Introduction. The role of independent directors in preventing shareholder expropriation}

Independent directors are considered as one of the main instruments against shareholder expropriation and for that reason their presence on corporate boards is recommended by national corporate governance codes and supranational institutions.

Parties in control of a corporation are in a position to extract private benefits of control that do not accrue to non-controlling shareholders. Such private benefits can be of a psychological nature (for instance the pleasure managers experience being at the top of a large organization) but can also take the form of wealth extraction at the expense of minority outside shareholders. ${ }^{2}$

One important focus of the corporate governance literature is on the mechanisms that may help limit wealth extraction. This issue is important because financial development, that is the willingness of investors to provide funds to companies, might be severely hampered in the absence of guarantees against wealth expropriation of outside investors. ${ }^{3}$

Adam Smith (1776), Berle and Means (1932) and Jensen and Meckling (1976), address the agency problem between managers and shareholders caused by dispersed ownership structure. The problem is that small shareholders lack economic incentives to spend resources to control management. As noted by Shleifer and Vishny (1997), large shareholders do have economic incentives to gather information and monitor management. By exercising their voting control, large shareholders do put pressure on management to act in shareholder interest. However, as showed by Demsetz (1983), Fama and Jensen (1985), and Grossman and Hart (1988), a concentrated share ownership structure also brings an incentive for controlling shareholders to expropriate minority shareholders. There is a danger that controlling shareholders use their influence to transfer corporate assets to themselves at below-market prices. ${ }^{4}$

The consequence is seen as having a direct impact on company economic performance, since in both cases the company is not run in the interest of (all) its suppliers of finance. Finally, even when a company manager pursues a profit-maximizing behavior, she may have incentive not to return the money to investors: for instance, instead of distributing dividends she may embark the company on costly investment projects. ${ }^{5}$

There is an increasing tendency in the financial, institutional and, to an important extent, academic world to see independent directors as an important preserve against the opportunism of management and controlling

\footnotetext{
2 Shleifer and Vishny 1997, p. 9-10.

${ }^{3}$ Shleifer and Vishny 1997, La Porta et al. 1997 and 1998.

${ }^{4}$ For a general introduction to the theory of conflicts of interest, see Kraakman, Davies et al. 2004, particularly sections 1,3 , and 5 .

${ }^{5}$ Shleifer and Vishny 1997, p. 10.
} 
shareholders. ${ }^{6}$ For instance, according to Bhagat and Black (2001), p. 232, there is a "conventional wisdom that the board's principal task is to monitor management, and only independent directors can be effective monitors." According to Gordon (2006) independent directors are an important part of the new corporate governance paradigm.

Practically all existing corporate governance codes or guidelines today contain a section on independent directors with varying (and, over time, increasing) proportions of independent directors recommended and with varying (and increasingly restrictive) definitions of independence. ${ }^{7}$ This trend is acknowledged by supranational institutions: the OECD Principles of Corporate Governance of 2004 recommend that boards should consider assigning a sufficient number of non-executive board members capable of exercising independent judgement to tasks where there is a potential for conflict of interest, ${ }^{8}$ while the point of view of the EC Recommendation on the role of non-executive and supervisory directors of $2005^{9}$ (hereafter EC Recommendation) is that independent directors have a role to play both in companies with dispersed ownership, where the primary concern is about how to make managers accountable to weak shareholders, and in companies with controlling shareholders, where the focus is more on how to make sure that the company will be run in a way that sufficiently takes into account the interests of minority shareholders.

In the academic literature, the origin of the argument which conceives the role of independent directors to be that of checking management tendency to pursue selfish goals goes back at least to Fama and Jensen (1983), who observe that optimal board structures require inside directors to be complemented by outside directors ${ }^{10}$ who should be especially entrusted

\footnotetext{
${ }^{6}$ Of course, independent directors are not the only measure allowing the prevention of such opportunistic behavior. See Dyck and Zingales 2004, p. 5-7, for a list of other possible factors able to limit the extraction of private benefits of control by controlling shareholders, and Hermalin and Weisbach 2003, p. 5-8, who propose the idea that boards of directors originally emerged as a guarantee against managerial misappropriation.

7 See Bhagat and Black 2001, p. 232, and OECD 2003, p. 62, for a list of institutions that recommend the presence of independent directors on company boards. The website of the European Corporate Governance Institute (www.ecgi.org) presents a complete list of the major corporate governance codes around the world. A comparison is provided by Weil, Gotshal \& Manges 2002.

8 OECD 2004. It is interesting to note that the Principles were endorsed by the OECD Meeting at Ministerial Level in May 2004.

${ }^{9}$ EC Recommendation of 15 February 2005, on the role of non-executive or supervisory directors of listed companies and on the committees of the (supervisory) board, http://europa.eu.int/eur-

lex/lex/LexUriServ/site/en/oj/2005/1_052/1_05220050225en00510063.pdf

10 According to Hermalin and Weisbach 2003, p. 2, "Inside directors are employees or former employees of the firm. They generally are not thought to be independent of the CEO, since the success of their careers is often tied to the CEOs. Outside directors are not employees of the firm and usually do not have any business ties to the firm aside from their directorships. Outside directors are typically CEOs from other firms or prominent individuals in other fields. Finally, about $10 \%$ of directors fall into neither category; often these are attorneys or businesspeople that have a longstanding relationship with the firm. These directors are usually referred to as 'affiliated' or 'gray' directors."
} 
with advising and policing the board on strategic decisions. The authors observe that outside directors are most apt to carry out tasks that involve potential conflicts of interest between managers and shareholders as they are less likely to collude with management to expropriate shareholders.

Among the ensuing contributions to the debate, Lorsch and MacIver (1989) indicate that independent directors are crucial because they can objectively evaluate and monitor firm activity. Byrd and Hickman (1992) observe that independent directors are responsible for protecting and promoting the interests of minority shareholders. Millstein (1993) calls for a "constructive tension" between shareholders and boards and between boards and managers, achieved by an independent credible board.

In Black (2001), independent directors are listed among the few "useful institutions" who can help shareholders in identifying disclosure problems. Their role is considered as particularly useful since independent directors, as opposed to investment bankers, accountants, and securities lawyers, are part of the board and can have a more complete perspective on the management. Eckbo (2005) calls for "a vigorous corporate governance system" to prevent shareholder rights being expropriated by corporate insiders.

Finally, in their corporate governance analysis the main rating agencies ${ }^{11}$ focus on the independence and effectiveness of the board of directors, of which the presence of a qualified number of independent directors is a key element.

\subsection{From director compliance to company compliance}

Even in Italy the presence of independent directors on corporate boards of listed companies is constantly increasing. ${ }^{12}$ But are those independent directors really independent?

To our knowledge, existing studies refer to board independence based on the number of directors qualified as independent by the issuer itself, and there are no systematic inquiries into whether listed companies in Italy ${ }^{13}$ really apply the independence standards they declare to follow. ${ }^{14}$

Our analysis falls within the boundaries of the new literature which examines transparency and disclosure by public companies concerning

11 For instance, Moody's recommends (Moody's 2003, p. 5) “a strong and clearly independent majority on the board, with audit, compensation and nominating/governance committees composed exclusively of independent directors."

12 See Assonime 2005.

13 Or in any other EU country.

14 This subject is actually at the frontier of corporate governance, at least in Europe, and it belongs to the wider field of whether regulatory authorities of some kind monitor the actual implementation of the various corporate governance codes that have been recently adopted in many EU countries. From OECD (2003), it emerges that such procedures do not exist or are not developed. 
corporate governance. Patel and Dallas (2002) review corporate disclosure patterns of more than 1,500 companies around the world. The study identifies 98 governance and financial-related disclosure items.

In Santella, Paone, Drago (2005) we analysed and quantified the extent to which corporate disclosure for the financial year 2003 allowed for verification of the independence of directors formally identified as independent by the 40 Italian blue chips. We used as a benchmark the voluntary requirements of the Italian Corporate Governance Code (Preda Code, 2002) and the voluntary requirements of the EC Recommendation (2005) on non-executive and supervisory directors (a proxy for international best practice). The aim of the exercise was to verify to what extent disclosure from Italian listed companies provided a minimum level of information on each independence requirement set by the Preda Code and by the EC Recommendation. We assigned three different rates: "yes" (compliance) when company disclosure showed that independent directors satisfied a specific independence requirement; "no" (non-compliance) when company disclosure contradicted a specific independence requirement; and "ns" in case of insufficient company disclosure.

We found that, for the two key independence requirements of not having business relationships with the company or an associated company and not having too many concurring commitments outside the company, the level of compliance ("yes" rates) is dramatically low: $4 \%$ and $16 \%$ respectively. Overall, it was possible to verify compliance with all the Italian independence standards for only 5 out of the 284 directors ${ }^{15}$ formally identified as independent by their companies, and for only 4 directors with respect to the EC standards.

The analysis made in Santella, Paone, Drago (2005) considered our population of 284 Italian independent directors as a single aggregate. In the present paper we move our analysis forward along two lines: we first separate our population in two groups: directors belonging to financial companies' boards and directors belonging to non-financial companies' boards; we then move on to aggregate directors according to the companies they belong to, so as to build a dataset of the first 40 Italian listed companies rated according to their disclosure of independence requirements. The paper is structured as follows: par. 1.2 illustrates data and methodology; section 2 compares compliance for directors sitting on financial and non-financial company boards; section 3 examines compliance at company level; section 4 examines the company networks identified by independent directors who sit at the same time on more than one company board; section 5 illustrates the relationship between company ratings and ownership concentration; and section 6 concludes.

\footnotetext{
${ }^{15}$ It is important to specify that in ten cases the same person sits on more than one board of
} the S\&P MIB Index, so that in the present study 284 refers to the number of directorships. 


\subsection{Data and methodology: measuring a microcosm}

The database used in this paper is built starting from the database created in Santella, Paone, Drago (2005). The aim of the exercise was to verify whether listed companies provided disclosure (to a reasonable extent) on the independence standards they declared to follow. ${ }^{16}$ Our chosen population 17 was made of the 284 independent directors who sit ${ }^{18}$ on the boards of the 40 listed companies that make the Italian S\&P - MIB index (about $80 \%$ of the total stock market capitalisation). The perspective chosen was that of the investor who should be in a position to verify, to a reasonable extent, the existence of the independence criteria of the corporate governance code the issuer declares to adopt. The empirical analysis was conducted on the basis of the documents referring to the financial year 2003, as published by the issuers and made available on the same issuers' websites or on the websites of the Italian stock market (Borsa Italiana) and the Italian stock market regulator (Consob).

The independence criteria considered in our database were those provided by the Italian Preda Code and by the EC Recommendation on the role of non-executive and supervisory directors of 2005. We chose as a first benchmark the Preda Code because it is the corporate governance code adopted by Borsa Italiana in 1999 and updated in 2002. ${ }^{19}$ Although the provisions set by the Preda Code are not mandatory, the bylaws set by Borsa Italiana ${ }^{20}$ require all Italian listed companies to present a yearly corporate governance report in which it must be mentioned whether and to what extent they have adhered to the Preda Code. We chose the EC Recommendation as a proxy for international best practice. The Recommendation, which is non-binding, concentrates on the role of nonexecutive or supervisory directors in key areas where executive or managing directors may have conflicts of interest. It includes minimum standards for the qualifications, commitment, and independence of non-executive or supervisory directors.

\footnotetext{
16 The purpose of the study was not to verify that independent directors of Italian blue chips are not independent in their actual behaviour; rather, it was to verify the extent to which listed companies justify compliance with independence requirements. As specified by the European Commission (2005), the determination of what constitutes independence should principally be an issue for the board itself to determine; however, proper information should be disclosed on the conclusions reached by the (supervisory) board in its determination of whether a particular director should be regarded as independent.

17 Since the 284 independent directors belong to the S\&P-MIB index, which represents about $80 \%$ of total Italian stock market capitalization, we may say that we analyse not just a sample of the Italian stock market, but its totality.

${ }^{18}$ On 31 December 2003.

${ }^{19} \mathrm{http}$ ://www.ecgi.org/codes/code.php?code_id=66 A new version of the Code was adopted in 2006 and will apply for the first time to the 2006 financial year: http://www.borsaitaliana.it/documenti/ufficiostampa/comunicatistampa/2006/presentazi onecodiceautodisciplina.htm

${ }^{20}$ Istruzioni al Regolamento dei mercati organizzati e gestiti da Borsa Italiana S.p.A dell'8 ottobre 2004, http://www.borsaitalia.it/opsmedia/pdf/14923.pdf
} 
We first identified the independence requirements introduced by the Preda Code and by the EC Recommendation, 5 and 7 respectively (see Table 1). ${ }^{21}$ We then moved on to verify to what extent disclosure from Italian listed companies provided a minimum level of information on each independence requirement. We assigned three different rates: "yes" is an indicator of compliance with independence criteria, it means that it is possible to verify from company disclosure that the independent director satisfies the independence criteria set by the Preda Code and by the EC Recommendation; "no" means that company disclosure contradicts a specific independence requirement: it is an indicator of non-compliance; "ns" means that it is not possible to verify from company disclosure the compliance or not compliance with the criterion (lack of disclosure). "Ns" should then be interpreted as a milder level of non-compliance than "no" that does not allow to assign a "yes" rate. ${ }^{22}$

In several cases the verification of independence requirements presupposes that a complete $\mathrm{CV}$ of the director be published. Besides, both the Preda Code and the EC Recommendation contain general clauses referring to the fact that independence criteria have to be interpreted with reference to significance thresholds. Since neither Borsa Italiana nor any of the issuers provided more guidance, we provided a specific evaluation of such significance thresholds, making use of available empirical evidence. Moreover, not all criteria, per se, allow for a thorough investor verification, short of investigative inquiries of some kind. The consequence is that the results of the present inquiry present an image of compliance with independence standards which could be more positive (or less negative) than the actual situation.

In the construction of the database we started attributing to every single independent director a rate ("yes", "no" or "ns") with respect to every independence criterion. The result was a matrix with 284 rows $\times 12$ columns, for a total of 3408 observations (each term in the matrix reflects an observation). So each term $a_{i, j}$ in the matrix corresponds to a single rate:

$$
A_{1}=\left(\begin{array}{ccccc}
a_{1,1} & a_{1,2} & a_{1,3} & \ldots & a_{1,12} \\
a_{2,1} & a_{2,2} & a_{2,3} & \ldots & a_{2,12} \\
a_{3,1} & a_{3,2} & a_{3,3} & \ldots & a_{3,12} \\
\ldots & \ldots & \ldots & \ldots & \ldots \\
a_{284,1} & a_{284,2} & a_{284,3} & \ldots & a_{284,12}
\end{array}\right)
$$

\footnotetext{
${ }^{21}$ Remark that EC and Preda criteria partially overlap: see in this respect Table 1. For more details on the independence criteria see Santella, Paone, Drago 2005, in particular Annex B. 22 Of course, we took into account the motivations provided, if any, by issuers who declared they considered independent a director who did not in principle satisfy a specific independence requirement. In this we followed the general rule recommended by Higgs (2003), p. 37: "The board should state its reasons if a director is considered to be independent notwithstanding the existence of relationships or circumstances which may appear relevant to its determination."
} 
Where:

$a_{i, j}=\{" y e s ", " n o ", " n s "\}$

$a_{i, j}$ refers to the $i$ company independent director (the main statistical unit) characterized by a rate ("yes" "no" or "ns") with respect to every $j$ criterion in Preda and in EC. All criteria can be considered as sets of criteria $s$ (in our case Preda and EC).

The first major additional item to the original data matrix $A_{1}$ was the division of our population of 284 independent directors in two categories, directors belonging to financial and directors belonging to non-financial companies ${ }^{23}$. The second major addition was the characterisation our population of directors according to the companies they belong to. As a result we have a data matrix $A_{2}$ which quantifies in all its dimensions the characteristics of each independent director ( pid ):24

$$
A_{2}=\left(\begin{array}{cccccc}
\operatorname{pid}_{1,1} & b_{1,2} & d_{1,3} & a_{1,4} & \ldots & a_{1,15} \\
\operatorname{pid}_{2,1} & b_{2,2} & d_{2,3} & a_{2,4} & \ldots & a_{2,15} \\
\operatorname{pid}_{3,1} & b_{3,2} & d_{3,3} & a_{3,4} & \ldots & a_{3,15} \\
\ldots & \ldots & \ldots & \ldots & \ldots & \ldots \\
\operatorname{pid}_{284,1} & b_{284,2} & d_{284,3} & a_{284,4} & \ldots & a_{284,15}
\end{array}\right)
$$

Where:

$$
\begin{aligned}
& b_{i, 2}=\{\text { " financial", "not_financial" }\}, i=1 \ldots 284 \\
& d_{i, 3}=\left\{\text { company }_{1} " . . . " \text { company }_{n} "\right\}, i=1 \ldots 284
\end{aligned}
$$

Although this data matrix refers to the population of Italian listed companies in $2003^{25}$, the same methodology can be applied to any other set of independence requirements (or of different qualitative outcomes). The conclusion is that our dataset is something more than a proxy for director independence sitting on Italian listed companies' board.

\footnotetext{
23 This is represented in a vector column $v_{1}=\left[\begin{array}{llll}b_{1} & b_{2} & b_{3} & \ldots\end{array}\right]^{T}$ where each $\mathrm{b}$ is the outcome "not financial" and "financial" referred to each independent director in the analysis. ${ }^{24}$ It is important to specify that each pid identifies the features of a specific independent director sitting on a specific company board. This means that the same physical person can have more than one pid according to the number of company boards he sits on.

${ }^{25}$ We stress that the data matrix depends crucially on the choices made at the start of the analysis. Different criteria $j$ used in the analysis (or different sets of criteria $s$ ) would generate different data matrices for the same independent directors. Obviously the methodology could be repeated to study the evolution over time of the compliance with independence criteria.
} 
The final result is that every one of our 284 directors has what we call a compliance pattern ${ }^{26}$ : the 12 cells of her row constitute her profile, that is how she performs according to the 12 independence requirements ${ }^{27}$. An important feature of our database is that there are no missing data, since as we said we attribute "ns" rate in case of lack of disclosure on a specific requirement. Moreover, our database links every director considered (or single row) to the company she serves in, accompanied by the further specification whether it is a financial or non-financial company, a primary differential characteristic between listed companies. We consider as financial companies banks and insurance companies.

The first important point is measuring the general compliance for $i$ by the $s$ set of criteria from the compliance pattern ${ }^{28}$. We compute from $A_{2}$ for each row or independent director $i$, considered here as a statistical unit:

$$
n c_{i, s \mid \text { financial }}=\sum y e s_{i, s \mid \text { financial }} ; n c_{i, s \mid n o t_{-} \text {financial }}=\sum y e s_{i, s \mid n o t_{-} \text {financial }}
$$

We obtain for each independent director (or row in $A_{3}$ ) the number of criteria satisfied $n c$ by set of criteria $s$. It is important to note that here we are equally weighting all $j$ criteria in the sets $s$ Preda and EC. We then move on to classify the independent directors in six and eight $c_{-}$yes classes of compliance (depending by $s$ ). We obtain $n_{c_{-} y e s, s}$ as the number of directors in a single class where $N_{s}$ represents the total. By considering percentages we compare financial and not financial profiles for each single class ${ }^{29}$ :

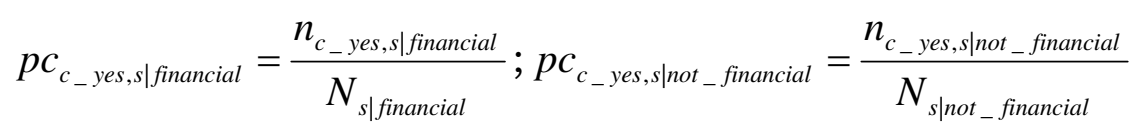

A comparison between the general compliance of the two sets of criteria $s$, jointly considered, could be obtained by cross-tabulating the number of independent directors by general compliance in each set of criteria ${ }^{30}$.

We explore the data to define more in depth the features of the matrix $A_{2}$ by analysing the different components of the sets of criteria Preda and EC separately. We start by each $j$ criterion in every set $s$ :

$$
f_{r, j, s \mid \text { financial }}=\frac{n_{r, j, s \mid \text { financial }}}{N_{j, s \mid \text { financial }}} ; f_{r, j, s \mid n o t_{-} \text {financial }}=\frac{n_{r, j, s \mid n o t_{-} \text {financial }}}{N_{j, s \mid n o t_{-} \text {financial }}}
$$

\footnotetext{
26 Referred directly to the single set of criteria $s$ of both Preda and EC.

27 We have for each independent director a compliance pattern. For instance we can have for a single independent director $i \quad p_{i}=[y e s, y e s, n o .$.$] using each column j$ as an independence criterion.

28 Results are in table 2 and table 3

29 Results are in table 2 and 3.

30 Results are in table 4.
} 
$n$ in this case is referred to the counts of one of all the three possible $r$ outcomes: "yes" compliance, "no" not compliance, or "ns" not disclosure, where $N$ is referred to the total observations. We obtain for each $j$ criterion in the $s$ set of criteria the compliance rate, the not compliance rate, and the not disclosure rate by financial and not financial companies.

Additional information could be obtained by considering more than one criteria jointly in a unique cross-tabulation, conditioning by financial and not financial to have more information about the data structure ${ }^{31}$.

We then move on to group all directors who belong to the same company $k$. This allows us to obtain from the 284 rows (the initial data matrix referred to all independent directors) 40 groups of rows (the global rates by company $k$ ). Every group of rows is formed by all directors belonging to the same company. For each group of rows we then calculate: $\left\{G_{k, s_{-} \text {yes }} ; G_{k, s_{-} n o} ; G_{k, s_{-} n s}\right\}$ which are the global rates of compliance, not compliance and not disclosure as follows:

$G_{k, s_{-} \text {yes }}=\frac{n_{1}}{\sum_{r=1}^{3} n_{r}}, G_{k, s_{-} n o}=\frac{n_{2}}{\sum_{r=1}^{3} n_{r}}, G_{k, s_{-} n s}=\frac{n_{3}}{\sum_{r=1}^{3} n_{r}}$

Where $n_{1}=\sum y e s_{k, s}, n_{2}=\sum n o_{k, s}, n_{3}=\sum n s_{k, s}, k=1 \ldots 40$

We obtain by construction: $G_{k, s_{-} y e s}+G_{k, s_{-} n o t}+G_{k, s_{-} n s}=1$. $n_{1}, n_{2}, n_{3}$ are the sum of the occurencies of the single rates computed, $r$ is the number of possible qualitative outcomes $\left(a_{i, j}=\{"\right.$ yes", "no","ns" $\left.\}\right)$ related to the independent director and $s$ the set of criteria Preda or EC.

As a result there are three company global rates $\left\{G_{k, s_{-} y e s}, G_{k, s_{-} n s}, G_{k, s_{-} n o}\right\}$ for each set of criteria (Preda, EC), that is the number of yes, ns, and not attributed to all independent directors belonging to each of the 40 companies divided by the total number of cells in the group ${ }^{32}$. For instance, if a company has three independent directors, in our database there will be 36 cells $(12 * 3$ cells). If the three directors have in total 24 yes rates out of 36 possible, we will attribute a total compliance rate of $0.66^{33}$. By construction,

${ }^{31}$ Results are in table 5.1 and 5.2

32 We calculate also $\Delta_{k_{-} \text {yes }}, \Delta_{k_{-} n o}, \Delta_{k_{-} n s}$ as the difference between global rates of the two sets of criteria analysed (Preda and EC). For instance: $\Delta_{k_{-} \text {yes }}=G_{k, e c_{-} \text {yes }}-G_{k, \text { preda } y e s}$ (results are shown in Table 8). This indicator is very important to characterize the typology of aggregate compliance for a company $k$ with respect to all criteria considered together (orientation to Preda and EC criteria or equilibrium between the two criteria)

33 $G_{k, s_{-} \text {yes }}=\frac{n_{1}}{\sum_{r=1}^{3} n_{r}}=\frac{24}{36}=0.66$ where $n_{1}=\sum$ yes $_{k, s}=24$ 
the sum of the three global rates is always 1 . The data matrix generated is represented in Table $8^{34}$.

Moreover, we also calculate a specific company rate for each independence criterion $G_{s, j}$ : we then have for each company a compliance rate ("yes"), a not disclosure rate ("ns"), and a non-compliance rate ("no").

$G_{k, s, j_{-} y e s}=\frac{n_{1, c o l_{k}}}{\sum_{r=1}^{3} n_{r, c o l_{k}}}, G_{k, s, j_{-} n o}=\frac{n_{2, c o l_{k}}}{\sum_{r=1}^{3} n_{r, c o l_{k}}}, G_{k, s, j_{-} n s}=\frac{n_{3, c o l_{k}}}{\sum_{r=1}^{3} n_{r, c o l_{k}}}$

Where $n_{1, c o l_{k}}=\sum y e s_{\text {col }_{k}}, n_{2, c o l_{k}}=\sum n o_{\text {colk }_{k}}, n_{3, c o l_{k}}=\sum n s_{c o l_{k}}, k=1 \ldots 40, j=1 \ldots 12$

We can then generalize the rates computed: computed rates by criterion (by considering columns $\mathrm{col}_{k}$ ), global company rates (submatrices) or global rates of entire sets of criteria (matrices) and so on.

In the comparative analysis of independence criteria, this means that each company will have 3 rates $\left\{G_{k, s, j_{-} y e s}, G_{k, s, j_{-} n s}, G_{k, s_{,} j_{-} n}\right\}$ for everyone of the 12 independence criteria, that is a compliance, non-compliance, and not disclosure rate for the business relationships requirement, a compliance, non-compliance, and not disclosure rate for the family ties requirement, and so on.

A complete company profile takes into account all the company features in (6) and (7). For a comparative evaluation of the profiles we consider the ranks ${ }^{35}$ over the S\&P MIB40 and a company score ${ }^{36}$ computed as:

$S_{k, s_{-} y e s}=\frac{G_{k, s_{-} y e s}}{\operatorname{Max}\left(G_{k, s_{-} y e s}\right)_{S \& P_{-} m i b}} ; S_{k, s_{-} n o}=\frac{G_{k, s_{-} n o}}{\operatorname{Max}\left(G_{k, s_{-} n o}\right)_{S \& P_{-} m i b}} ; S_{k, s_{-} n s}=\frac{G_{k, s_{-} n s}}{\operatorname{Max}\left(G_{k, s_{-} n s}\right)_{S \& P_{-} m i b}}$

Where $\left\{\operatorname{Max}\left(G_{k, s_{-} y e s}\right)_{S \& P_{-} m i b} ; \operatorname{Max}\left(G_{k, s_{-} n o}\right)_{S \& P_{-} m i b} ; \operatorname{Max}\left(G_{k, s_{-} n s}\right)_{S \& P_{-} m i b}\right\}$ are the maximum values in the S\&P MIB index for the same global rate (compliance, not compliance and not disclosure) in the year 2003.

Similarly for the single criteria, we obtain:

$$
S_{k, s, j}=\frac{G_{k, s, j}}{\operatorname{Max}\left(G_{k, s, j}\right)_{S \& P_{-} m i b}}
$$

\footnotetext{
34 Table 6,7, and 9 provide a visualization and a sort of "visual ranking" of Table 8.

${ }^{35}$ Each ranking is done by sorting from the maximum to the minimum value and assigning the highest possible rank whenever two or more companies are characterized by an equal global rate.

${ }^{36}$ In Table 8.2 (multiplied by 100)
} 
Where $\left\{\operatorname{Max}\left(G_{k, s, j}\right)_{S \& P_{-} m i b}\right\}$ represents the maximum value for the $j$-th criteria in the S\&P MIB for the year 2003.

As an ulterior step in our methodology, we generate from (2) ${ }^{37}$ the adjacency matrix of the cross-directoships ${ }^{38}$ which allows to consider the companies involved in cross-directorship links in S\&P MIB. ${ }^{39}$

$$
A_{3}=\left(\begin{array}{ccccc}
- & z_{12} & z_{13} & \ldots & z_{1,40} \\
z_{2,1} & - & z_{2,3} & \ldots & z_{2,40} \\
z_{31} & z_{3,2} & - & \ldots & z_{3,40} \\
\ldots & \ldots & \ldots & - & \ldots \\
z_{40,1} & z_{40,2} & z_{40,3} & \ldots & -
\end{array}\right)
$$

Where $A_{3}$ is typically a symmetric matrix where $z_{k_{1}, k_{2}}=\{0,1\}, k_{1}=1 \ldots 40, k_{2}=1 \ldots 40$

$A_{3}: z_{k_{1}, k_{2}}=1$ implies a cross-directorship between the companies ${ }^{40} k_{1}$ in the row and the company $k_{2}$ in the column; $z_{k_{1}, k_{2}}=0$ on the contrary implies the the nonexistence of a cross-directorship link. We do not consider the main diagonal of the matrix $A_{3}$ as referred to the same $k$ company in the row and in the column.

The symmetric matrix (10) in an enlarged version comprehensive of all the companies involved in cross-directorship schemes (inside and outside the

\footnotetext{
${ }^{37}$ In particular: 1) we consider all rows with the qualitative outcome in the EC requirement crossdirectorships="not"; 2) we collect data referring to specific features of this qualitative outcome by verifying whether each independent director is part of a crossdirectorships scheme according to the definition given by the EC Recommendation; 3) we cross-tabulate by companies involved in the relationship. The result is the data matrix (10)

38 Such matrix is actually a social network dataset. See Wassermann, Faust and Iacobucci (1994)

${ }^{39}$ Since $A_{4}=A_{4}{ }^{T}$ we have a symmetric matrix (cross-directorships are possible considering the same $k$ companies as nodes).

40 One is assigned whenever a company is part in a cross-directorship (see section 4 for the definition of cross-directorships) link: either actively (meaning that the company does not satisfy the independence requirement) or passively, meaning that the company is simply a host for the two directors serving in the first company. For instance, if we assume that company $\mathrm{X}$ has an independent and an executive director who also sit on company $\mathrm{Y}$ board as non executives, then company $\mathrm{Y}$ will be compliant with the cross-directorships requirement, but will receive 1 in the present matrix because it is the company linked to company $\mathrm{X}$ through the cross-directorships.
} 
S\&P MIB) ${ }^{41}$, can be represented as a graph $H(V, E)$ where there is a set of vertices or nodes $V$, the companies, and a set of edges or ties $E$ representing the independent director $i$ involved in the cross-directorship. The crossdirectorship is a symmetric relationship between two companies $k_{1}$ and $k_{2}$ so that $E\left(k_{1}, k_{2}\right)$ also implicates $E\left(k_{2}, k_{1}\right)$. In the matrix there is an $E\left(k_{1}, k_{2}\right)$ for every $z_{k_{1}, k_{2}}=1$ that links two vertices of companies $k^{42}$.

We define a cross-directorships network as an aggregation of vertices $V$ (companies $k$ ) linked by edges $E$ (in our case independent directors $i$ ). We can have different geometrical structures due to the distribution of independent director $i$ over the 40 companies. Important features of these networks (that we can compare longitudinally studying the evolution over time) are betweeness, centrality (measures of "centrality" and "power" for each company \vertex) and closeness (a measure of "perifericity") 43.

From matrix (10) we obtain the total number of cross-directorships by company as the sum of each row:

$$
C_{k_{1}}=\sum_{k_{2}=1}^{40} z_{k_{1}, k_{2}}=\sum \operatorname{cross}_{i, k}, k=1 \ldots 40, i=1 \ldots 284, k_{1}=1 \ldots 40
$$

Where cross $_{i}$ represents cross-directorships by company independent director.

We finally add another adjacency matrix from $(2)^{44}$, where each cell is given value 1 whenever the same independent director also sits on another board of the 40 listed companies of our population as an independent.

$$
A_{4}=\left(\begin{array}{ccccc}
- & u_{12} & u_{13} & \ldots & u_{1,40} \\
u_{2,1} & - & u_{2,3} & \ldots & u_{2,40} \\
u_{31} & u_{3,2} & - & \ldots & u_{3,40} \\
\ldots & \ldots & \ldots & - & \ldots \\
u_{40,1} & u_{40,2} & u_{40,3} & \ldots & -
\end{array}\right)
$$

${ }^{41} A_{3}=\left(\begin{array}{ccccc}- & z_{12} & z_{13} & \ldots & z_{1,50} \\ z_{2,1} & - & z_{2,3} & \ldots & z_{2,50} \\ z_{31} & z_{3,2} & - & \ldots & z_{3,50} \\ \ldots & \ldots & \ldots & - & \ldots \\ z_{50,1} & z_{50,2} & z_{50,3} & \ldots & -\end{array}\right)$

42 Results are shown in Table 11

${ }_{43}^{43}$ See Wassermann Faust and Iacobucci (1994)

${ }^{44}$ In particular we consider all rows with the same independent directors (same "pid" as in matrix 2); we then cross-tabulate by companies involved in the relationship. 
Where $A_{4}$ is typically a symmetric matrix with the same properties of $A_{3}$. $u_{k_{1}, k_{2}}=\{0,1\}, k_{1}=1 \ldots 40, k_{2}=1 \ldots 40$ and $u_{k_{1}, k_{2}}=1$ indicates the existence of a dualdirectorship between the companies $k$ in the row and in the column $u_{k_{1}, k_{2}}=0$ means that the dual-directorship does not exist.

At the same time we calculate the total number of dual-directorships by company:

$D_{k_{1}}=\sum_{k_{2}=1}^{40} u_{k_{1}, k_{2}}=\sum \operatorname{dual}_{i, k}, k=1 \ldots 40, i=1 \ldots 284, k_{1}=1 \ldots 40$

Similarly than (10) we can represent graphically (12) as a network ${ }^{45}$.

Where in $A_{3}$ and in $A_{4}$ we consider the existence of cross-directorships and dual-directorships relationships between companies in columns and in rows we now consider jointly these characteristics. We obtain a new network (and a new adjacency matrix $A_{5}$ ) that represents the $\mathrm{k}$ companies $\backslash$ nodes with edges characterized by: cross-directorships, dual-directorships, and the sum of dual-directorships and cross-directorships between the $k$ companies part of the scheme ${ }^{46}$.

So in this analysis we consider $z_{k_{1}, k_{2}}$ and $u_{k_{1}, k_{2}}$, already seen separately, as different attributes or characteristics of the same linkage between two companies $^{47}$, as we can observe in the adjacency matrix $A_{5}$.

As structural aspects we consider primarily size and descriptive statistics through company network. It is possible to characterize every actor in the network using the company profiles seen in (6) and (7). As $n$ attributes of the node $V$ could be considered: the level of the compliance and the incidence of the cross-directorships and dual-directorships ${ }^{48}$.

To measure the relevance of the cross-directorships and dual-directorships, we calculate for the $k$-th company the $I C_{k}$ index, defined as the incidence of cross-directorships, and the $I D_{k}$ index defined as the incidence of dualdirectorships:

\footnotetext{
45 See Table 12 for the result.

46 Values for the index representing the complete (multiplex) characterization of the relationship between two S\&P-MIB companies are: no directorships at all $=0$, cross directorships $=1$, dual-directorships $=2$, cross directorships and dual-directorships $=3$. See Hannemann Riddle (2005)

47 Results are in Table 13

48 In particular see for the results Table 11,12 and 13. As quality attribute we use in Table 11 the EC global rate and the incidence of the cross-directorships, in Table 12 the number of the dual-directorships and the incidence of the dual-directorships, and in Table 13 the average of the EC\Preda global rate.
} 
$I C_{k}=\frac{C_{k}}{D i_{k}} ; I D_{k}=\frac{D_{k}}{D i_{k}}$

Where $C_{k}=\sum \operatorname{cross}_{i, k} ; D_{k}=\sum d u a l_{i, k}$ and $D i_{k}$ is the number of company independent directors. $C_{k}$ is computed as the sum of cross-directorships by company, $D_{k}$ as the sum of dual-directorships by company. At the same time, by considering independent directors that present both a cross-directorship and a dual directorship we calculate:

$I C D_{k}=\frac{C D_{k}}{D i_{k}}$

Where $C D_{k}$ is the characteristic for an independent director to be part at the same time of a cross-directorship and a dual directorship link ${ }^{49}$.

\section{Compliance with independence requirements of directors belonging to financial and non-financial companies ${ }^{50}$}

From Table 2 it is possible to notice that directors belonging to non-financial companies show a higher level of compliance than those belonging to financial ones. While in the former case 5 directors out of 101 (5\%) are compliant with all five Preda criteria, in the latter case no director out of 183 is compliant with all five criteria. The results do not change if we consider the compliance with four out of five Preda criteria: 9 directors out of 101 $(9 \%)$ belonging to not-financial companies are compliant while for directors belonging to financial companies the result is 7 out $183(4 \%)$. If we consider the number of directors who show compliance with at least 4 criteria, we have 14 out of 101 for directors belonging to not-financial companies (14\%) and 7 out of 183 for directors belonging to financial companies (4\%).

In table 3 we make the same exercise referring to the EC criteria, and we observe that the situation does not change. While for directors belonging to non-financial companies 4 directors out of 101 (4\%) are compliant with all seven EC criteria, in the case of directors belonging to financial companies no director out of 183 is compliant with all seven criteria. If we consider the number of directors who show compliance with six out of seven criteria, in case of not-financial companies 8 directors out of $101(8 \%)$ are compliant while for financial companies the result is 4 out $183(2 \%)$. If we consider the number of directors who show compliance with at least 6 criteria, we have 12 out of 101 for those belonging to not-financial companies (12\%) and 4 out of 183 for those belonging to financial companies $(2 \%)$.

\footnotetext{
${ }^{49}$ Results are in Table 14.

50 Results are obtained using Stata (version 9.0), R (2.4.0), Ucinet (6.0) and Microsoft Visual Basic (6.3). See R Development Core Team 2006, StataCorp 2005 and Borgatti, Everett, Freeman 2002. Results are obtained by programming to repeat the application over time and space.
} 
In Table 4 we consider joint compliance with all Preda and EC criteria. We observe that for directors belonging to both financial and not-financial companies the bulk of the distribution is at the center: in the case of directors belonging to not-financial companies the highest number of directors can be found at a level of compliance of 3 out of 5 Preda criteria and 5 out of $7 \mathrm{EC}$ criteria, while for directors belonging to financial companies the highest number of directors can be found at 3 Preda criteria and 4 EC criteria. Such results indicate that there are at least two key Preda and EC independence criteria that have a very low level of compliance. The purpose of the next two sub-sections is to identify these criteria.

\subsection{Comparative compliance with Preda criteria (and with 4 EC criteria)}

In the previous section we have examined the different level of compliance with independence requirements between directors belonging to financial and not-financial companies with reference to all five Preda independence criteria and all seven EC criteria. In this sub-section we move on to analyse their comparative compliance concerning each specific Preda criterion. 4 out of 5 of such criteria are also common to the EC Recommendation ${ }^{51}$ while the Shares Owned requirement belongs only to the Preda Code.

\section{Professional Qualification, Shares Owned and Family Ties}

In Santella, Paone, Drago (2005) we noticed that there is a first set of criteria that shows a higher level of compliance and a second set of criteria which shows a significantly lower level of compliance. The first is: Professional Qualification, Family Ties, and Shares Owned. Professional Qualification and Family Ties are very difficult to verify through company disclosure. There is still a very wide debate in the academic literature and in the financial community on the meaning of professional qualification, which led us to attribute a compliance rate whenever it was possible to find even very synthetic information on the director's profile. As for Family Ties, short of an investigative analysis, this is a requirement for which we decided to rely on company statement (where present) that the independent director satisfied this requirement. This means, among other things, that for this requirement it is practically impossible to have "no" rates. Finally, the requirement Shares Owned is fully verifiable from company disclosure and it reveals that in general Italian independent directors do not own significant shareholdings in the companies they belong to.

It is possible to see from Table 5 that compliance with these three criteria is not much differentiated among directors belonging to non-financial and financial companies.

\footnotetext{
${ }^{51}$ With the difference between EC Business Relationships and Preda Business Relationships
} illustrated in Table 1. 

disclosure

We now look at two Preda and EC criteria, Business Relationships and Other Commitments. In Table 5 we may see that the bulk of non-compliance ("no" and "ns" rates) is concentrated in these two criteria. In particular, compliance with Preda Business Relationships is higher for directors belonging to non-financial companies (9\% vs none), who also show a higher level of not compliance rates (16\% vs $8 \%)$. This outcome, which could appear at a first sight as contradictory, should be interpreted taking into account that directors belonging to non-financial companies also show a higher level of transparency (given by the lower level of not disclosure "ns" rates, $75 \%$ vs $92 \%)$. On the other hand, directors belonging to financial companies have a lower level of disclosure (higher level of not disclosure "ns" rates). These results suggest that behind their high percentage of not disclosure rates directors belonging to financial companies might hide cases of not compliance. In the case of EC Business Relationships, financial companies show a significantly higher level of "no" rates than in Preda Business Relationships. This is due to the fact that the EC Recommendation considers being part of the executive committee as incompatible with director independence. This difference between the two criteria will be more deeply analysed later on in this paper when we will examine compliance according to each individual company (see Section 3).

In the case of Other Commitments, the most interesting information given by Table 5 is the low level of not disclosure ("ns" rates) for both directors belonging to financial and not financial companies. This corresponds to a very high level of non-compliance ("no" rates) for directors belonging to both classes of companies, although not-financial companies fare slightly better $(65 \%$ vs $71 \%)$. It is interesting to notice that the high level of disclosure is connected to mandatory disclosure by Italian Consob on the number of boards where independent directors sit at the same time. This also gives a hint about what could be behind the lack of transparency observed for the previous requirement.

Table 5.1 illustrates the relationship between Business Relationships and Other Commitments. In the case of Preda criteria (upper part of the table), we notice that $60 \%$ of our 284 directors show not compliance ("no") with Other Commitments together with not disclosure ("ns") with Preda Business Relationships. The table also shows that more than $80 \%$ of our population do not show compliance with any of the two criteria considered. The same reasoning applies to the second couple of criteria (EC Business Relationships/Other Commitments), where more than $80 \%$ of our population also do not show compliance with any of the two criteria. However, in this case there is a higher incidence of directors who show not compliance with respect to the two criteria at the same time.

Table 5.2 represents the same infomation as Table 5.1 distinguishing by company typology (financial and not financial). It appears that financial 
companies show a higher level of not compliance and not disclosure on our two couples of requirements.

\subsection{Comparative compliance with the three remaining EC criteria}

In this sub-section we examine the comparative compliance of independent directors belonging to financial and not-financial companies with each of those EC criteria that are not included in Preda (see Table 1), that is, CrossDirectorships, Permanence on the Board and Additional Remuneration.

\section{Cross-Directorships}

From Table 5 it is possible to notice that the level of compliance with the Cross-Directorships requirement is very high for directors belonging to both financial and not-financial companies (85\% and $95 \%$ respectively). Thanks to the mandatory disclosure from Italian authorities mentioned in the previous sub-section, in this case not disclosure is not possible: directors must declare in which other boards they sit at the same time. However, a limited number of directors have a "no" rate in this criterion, which means that they are part in cross-directorship schemes. About $85 \%$ of such directors (27 out of 32) belong to financial companies. This contributes to explain why financial companies have a lower rate of compliance than non-financial ones.

\section{Permanence on the Board and Additional Remuneration}

From Table 5 it emerges that compliance with the Permanence on the Board requirement is not very high, particularly with reference to directors belonging to financial companies. On the other hand, directors belonging to both categories of companies show a higher rate of compliance with Additional Remuneration, which means that in general independent directors do not receive significant variable compensation from the company they belong to.

The conclusion for this entire section is that independent directors belonging to financial and non-financial companies show a low level of compliance with both Preda and EC requirements, although the level of compliance is higher for those directors who sit on non-financial companies' boards. For directors belonging to both financial and non-financial companies, such low level of compliance is attributable in the first place, to two key Preda and EC requirements: Business Relationships and Other Commitments. As for the fact that non-financial companies fare better than financial companies, this is attributable in the first place to the better performance of directors belonging to non-financial companies in Business Relationships and Other Commitments. Moreover, in a limited but important number of cases independent directors are part of cross-directorships schemes, especially directors belonging to financial companies. Finally, compliance with the Permanence on the Board criterion is not very high, particularly with reference to directors belonging to financial companies. 


\section{Company compliance with independence requirements}

We now calculate global rates for compliance ("yes"), not compliance ("no") and not disclosure ("ns") by company by regrouping our population of 284 independent directors according to the 40 companies they belong to ${ }^{52}$. We then calculate the frequency of "yes", "ns", and "no" rates for each company with respect to all Preda and EC independence criteria, obtaining what we call six global rates. All independence criteria are equally weighted. Table 8 and Table 8.1 provide compliance, not disclosure, and not compliance global rates for all Preda and EC criteria. Table 15 provides the same information according to company ranking in each of the six global criteria. ${ }^{53}$

\section{Company ranking by compliance ("yes") rates}

We refer here to Table 8, 8.1, 10 (which focuses more in particular on each criterion as a component of the global company rate) and 15 . With reference to EC criteria, Fiat is the company that shows the best compliance rate. Fiat is also the leader of a group of better performing companies, which is formed also by Enel, Finmeccanica, Telecom Italia, ENI, Snam Rete Gas, Mondadori, Fastweb, Autostrade, Telecom Italia Mobile, Seat. At the bottom of the ranking we find a group of companies formed by L'Espresso, SanPaolo IMI, Benetton, STMicroelectronics, Italcementi, Banco Popolare di Verona e Novara, Bulgari, Alleanza, Banche Popolari Unite, etc. The situation does not change if we make reference to the global compliance rates according to Preda criteria. Both on top and at the bottom of the ranking we find, although with slight changes in relative position, the same group of companies as in EC. This means that companies that perform well according to EC criteria also perform well according to Preda criteria and vice versa. A few interesting exceptions are represented by the two cooperative banks Banche Popolari Unite and Banco Popolare di Verona e Novara and Italcementi. This can be explained by the similarity (but not identity) of the two sets of criteria (see Table 1). In particular, the lower performance of Italcementi and the two cooperative banks is attributable mainly to their performance concerning EC Business Relationships and Additional Remuneration.

We also observe from Table 8, 8.1 and Table 15 that in general financial companies tend to show a lower level of compliance compared to notfinancial ones both according to EC independence criteria and to Preda criteria. This result corresponds to the evidence shown in section 2 . We also observe that the best performing companies are mostly utilities (Enel, Eni, Telecom) and non-financial companies with a relatively dispersed shareholder base (Fiat). We finally observe that most of the companies that

\footnotetext{
${ }^{52}$ See equation 6

${ }^{53}$ Table 6 and Table 7 also provide a visual comparison for our 40 companies according to the combination of "yes" and "ns" rates for Preda criteria (Table 6) and EC criteria (Table 7). As a visual aid the table also depicts the regression line estimated with ordinary least squares for financial and not financial companies. The red line represents the $50^{\text {th }}$ percentile for the variable considered.
} 
are placed at the lower end of the compliance distribution are linked by cross-directorship and cross-ownership links. We will explore the implications of this observation in section 4 .

\section{Company ranking by not disclosure ("ns") rates}

We now move on to examine performance according to not disclosure ("ns") and not compliance ("no") rates making reference to Table 8 and particularly to Table 15. With reference to EC criteria, there is a group of companies that shows a particularly low level of disclosure (high not disclosure, "ns", rates) formed first of all by L'Espresso, Bulgari, Benetton, Alleanza, and so on. Symmetrically, there is a group of companies that shows a high level of disclosure, starting with Fiat, Finmeccanica, Enel, Luxottica. With reference to Preda criteria, even in this case the results are globally similar to the EC criteria: companies that show a low level of disclosure according to EC criteria also tend to have a low level of disclosure according to Preda criteria, while companies that show a high level of disclosure according to EC criteria also tend to have a high level of disclosure according to Preda criteria.

\section{Company ranking by not compliance ("no") rates}

As for performance according to not compliance rates, Table 8 and particularly Table 15 show (with reference to EC criteria) a group of companies with a particularly low level of "no" rates, formed first of all by Bulgari, l'Espresso, Mediolanum, Autostrade, Mediaset. Symmetrically, there is a group of companies that show a high level of "no" rates, starting with STMicroelectronics, Banche Popolari Unite, Monte dei Paschi, Luxottica, Sanpaolo IMI. With reference to Preda criteria, even in this case the results are globally similar to the EC criteria: companies that show a low level of "no" rates according to EC criteria also tend to have a low level of "no" rates according to Preda criteria, and vice versa.

\section{Joint compliance}

Now we move on to examine company performance by considering jointly the three rates according to EC and Preda independence criteria. From Table 15 we can see that companies that have a high disclosure level (low "ns" rates) are also those who show a high compliance level. However, those same companies also show a high level of "no" rates: Fiat, Enel, Eni etc. Moreover, there are a few companies that have a low level of disclosure and a high level of "no" rates: STMicroelectronics, Luxottica, SanPaolo IMI. The same results apply to EC and Preda criteria ${ }^{54}$

\footnotetext{
${ }^{54}$ Table 9 provides a visual comparison for the joint compliance rates in Preda and EC. The red line represents the $50^{\text {th }}$ percentile for the variable considered.
} 


\subsection{Company compliance by single independence criterion}

We now disaggregate our three global rates (compliance, not disclosure, and not compliance rates) in single rates according to each criterion. ${ }^{55} \mathrm{We}$ refer here to Table 10 (which resumes relative company performance by criteria) and to Appendix A, Company rankings according to each Preda and EC criteria and Comparative company rankings by EC and Preda criteria.

Beginning with the Preda Business Relationships requirement, we saw in section 2 that this was the requirement that showed (together with Other Commitments) the lowest compliance rates for directors belonging to both financial and not-financial companies, and that the latter fared better than the former. Here we have the opportunity to verify how such results translate in terms of companies. From Annex A we see that 32 companies out of 40 have a compliance rate equal to zero and that the 8 companies that have a positive compliance rate are non-financial companies which are also characterised by a relatively dispersed ownership base. This translates (Table 5) into the fact that overall not financial companies have a $9 \%$ compliance rate with this requirement against none from financial companies. The same results apply to EC Business Relationships.

We now move on to the Other Commitments requirement which is the other requirement which we indicated in section 2 as responsible for the low level of compliance to Preda requirements. In this case (see Appendix A) even those companies that perform better (both financial and non-financial ones) do not have very high compliance rates. This means that independent directors belonging to all the 40 Italian Blue Chips tend to have a high number of concurring board commitments. Again, looking at Table 5 we notice that overall not-financial companies have higher compliance rates (23\% against $13 \%)$.

A further verification comes from Table 5.2 which compares compliance with both Business Relationships and Other Commitments criteria. The table shows that not-financial companies have a higher joint compliance to these two criteria. The Cross Directorships requirement allows us to have a clearer picture of the implications of such fact. We observe here in the first place those 15 companies with a compliance rate lower than $100 \%$, that is those companies that have at least one independent director who is part of a crossdirectorship scheme. The majority of them (11 out of 15$)$ are financial companies, and the other two are not-financial companies with concentrated ownership base together with Telecom Italia and its controlling company, Pirelli. We then conclude that although independent directors belonging to all 40 company boards have a high number of concurring board commitments, those belonging to financial companies tend to be part in cross-directorship schemes.

\footnotetext{
55 See also equation 7.
} 
We now move on to the second requirement which is specific to EC criteria, Permanence on the board. We observed in the previous section that compliance with the Permanence on the Board criterion is not very high, particularly with reference to directors belonging to financial companies. Here we find that in fact financial companies tend to position themselves at the lower end of the ranking, even in this case together with non-financial companies characterized by a concentrated shareholder base.

To sum up the results of this section we find confirmation at company level that compliance is in general very low for two key independence requirements, Business Relationships and Other Commitments. Moreover, taking into consideration compliance to all independence requirements, we also notice that the lower compliance level found in section 2 for directors belonging to financial companies translates here in poorer performance at company level for financial companies. Interestingly, such poor performance tends to be shared by non-financial companies with a concentrated ownership base, which means that the companies that actually stand out are those non-financial companies with a dispersed shareholder base, something which it was not possible to see in section 2. Finally, as regards company compliance to specific requirements, non-financial companies with relatively dispersed shareholder base tend to perform best in those key criteria responsible for the general low compliance rate of our population, with the important specification that independent directors belonging to all the 40 companies tend to have a high number of concurring commitments. We explore the implications of this last aspect in the next section.

\section{The networks of Cross-Directorships and Dual-Directorships}

In the previous section we have observed that independent directors sitting on all 40 companies' boards tend to sit in several other boards and that for 15 out of 40 companies this translates in having at least one independent director who is part of cross-directorship schemes. We remind that crossdirectorships involve two directors (one independent and one executive) who also sit on another company board at the same time. In the first part of this section we will examine the network of cross-directorship links established by the 40 companies belonging to our population. In the second part we will enlarge the picture by considering also the links between companies that have the same independent director on their boards (dual-directorships).

We start looking at the network of cross-directorship links. We observe (Table 11) that Mediobanca and Ras show the highest number of crossdirectorships (four). Moreover, such two companies belong to the same cross-directorship network which includes several other financial companies, in the first place Capitalia and Unicredito, which both have controlling stakes in Mediobanca. ${ }^{56}$ There is also an important role of SAI Fondiaria with

\footnotetext{
${ }^{56}$ We remind that the Mediobanca investment bank has had a de-facto role of guarantor of company equilibrium in Italy throughout the second post-war period by owning stakes in the most important Italian listed companies. Mediobanca was managed with the aim to
} 
three cross-directorships. Finally, at the periphery of this network we find such non-financial companies as Pirelli, Telecom, Fastweb (the first company considered is characterized by 2 cross-directorships while the others by one).

We also observe two other smaller networks which have at their center respectively Sanpaolo Imi and Banco Popolare di Verona e Novara (each one characterized by two cross-directorships). We finally observe six couples of companies connected by cross-directorship links.

The prominent position of financial companies in cross-directorship networks is a confirmation of what we have seen in section 3 , that those independent directors involved in cross-directorship schemes for a large majority sit on financial companies' boards.

\section{Adding Dual-Directorships to Cross Directorships}

Cross-directorship networks can be enlarged including dual-directorships, which we define as involving one independent director who sits on another company board at the same time as an independent. It is a looser link compared to cross-directorships, which involve two directors (one independent and one executive) who sit on another company board at the same time. The first thing we observe (Table 12) is that dual-directorships involve companies that are also part of cross-directorships networks but also companies that are not. Besides, a few companies (Unicredito, Generali and Eni) have more than one dual-directorship link with another company. We also observe the emergence of a new network formed by Eni, Autostrade and Mondadori.

In Table 13 we add dual-directorship links to cross-directorship networks. We observe a very significant enlargement of the Mediobanca network to such companies as Generali, RCS Mediagroup, Banche Popolari Unite and others (28 companies in total). We notice that the Mediobanca network now looses its characteristic of being mostly made of financial companies. We associate this finding with the fact identified in section 3: even those companies that show the best compliance rates have not very high rates. This is in turn due mainly to relational requirements (Business Relationships and Other Commitments).

Table 13 also allows to consider the association of our independence ratings with each company belonging to cross-directorships and dual-directorships networks. We observe that in general companies belonging to the same network tend to have the same compliance range. Companies that share only dual-directorship links have in general higher compliance rates compared to companies connected by cross-directorship links. This is for instance the case of the network Eni-Autostrade-Mondadori.

support Italian industrial families' controlling ownership stakes and to broker them credit financing from the then government-owned banking system (see De Cecco and Ferri 1986). 
Finally, we also analyse the incidence of dual-directorships and cross directorships on the total number of independent directors. ${ }^{57}$ The results (Table 14) show that companies that are part of company networks also tend to have a higher incidence of cross and dual-directorships. This is particularly the case for the Mediobanca network. The conclusion in this respect is that companies that belong at the same time to cross and dual directorship networks tend to do so with a high proportion of their independent directors.

\section{Company ratings and ownership concentration}

In section 3 we observed that non-financial companies belonging to our population can be divided at least in two groups: those which are characterized by higher compliance rates and relatively dispersed ownership structure and those which are characterized by lower compliance rates and concentrated ownership structure. We now try to explore more in depth the features of the companies that belong to such groups.

Looking at Table 16,17 and 19 we find that those non-financial companies that have a relatively fragmented shareholder structure 58 (measured by the percentage of small shareholders holding less than $2 \%$ of total voting rights) tend to have higher levels of compliance and disclosure (but not always by lower levels of not compliance, see table 8.1). This is also confimed by Table 18 which shows a positive correlation coefficient ${ }^{59}(r=0.56$ capital voting on Preda compliance and $r=0.47$ on EC compliance ${ }^{60}$ ) between compliance rates and the percentage of the total voting capital held by shareholders owning less than $2 \%$ of the same voting capital (free-float). The same

57 We remind that we compute by company $k$ the $I_{c, k}$ incidence of cross-directorships and the $I_{d, k}$ incidence of dual-directorships:

$$
I C_{k}=\frac{C_{k}}{D i_{k}} ; I D_{k}=\frac{D_{k}}{D i_{k}}
$$

Where $C_{k}=\sum \operatorname{cross}_{i, k} ; D_{k}=\sum d u a l_{i, k}$ and $D I_{k}$ is the number of company independent directors. $C$ is computed as the sum of cross-directorships by company, $D$ as the sum of dual-directorships by company. For example $I C_{k}=\frac{C_{k}}{D i_{k}}=\frac{1}{9}=0.11$ and $I D_{k}=\frac{D_{k}}{D i_{k}}=\frac{2}{9}=0.22$ where $C_{k}=\sum \operatorname{cross}_{i, k}, D_{k}=\sum d u a l_{i, k}=2 D i_{k}=9$

${ }^{58}$ Cooperative Banks (Banche popolari) are not considered due to the different shareholder
voting rules (one-shareholder-one-vote).
${ }^{59}$ Simply calculated as the population correlation $r=\frac{n \sum x \cdot y-\sum x \sum y}{\sqrt{n \sum x^{2}-\left(\sum x\right)^{2}} \cdot \sqrt{n \sum x^{2}-\left(\sum x\right)^{2}}}$. Missing value treatment: listwise deletion. See Little, Rubin (1987) 
phenomenon is depicted in Table 16 where we have four scatter diagrams comparing the relationship between compliance rates and free-float for nonfinancial and financial companies according to Preda criteria (left-hand side of the diagram) and EC criteria (right-hand side of the diagram). ${ }^{61}$

The explanation we give is that small shareholders are particularly interested in having independent directors on the board to prevent conflicts of interest from management and controlling shareholders. It emerges from our population that small shareholders do not obtain high disclosure level from their companies when they are under a critical level: their transaction costs being high, they need to be relatively numerous compared to controlling shareholders to make themselves heard.

However, we also notice from Tables 16 to 18 that the same relationship does not hold for financial companies, something which is also confirmed by Table 19 which shows that there is no appreciable correlation between compliance rates and the percentage of total voting capital held by shareholders owning less than $2 \%$ in financial companies $(r=0.04$ Preda and $r=0.05$ EC). Financial companies tend to show low compliance rates despite they often show a fragmented shareholder structure. We observe in this respect that the fact that banks and insurance companies are also subject to strong financial supervision (see for instance Levine 2004) does not seem to have a positive influence as far as disclosure on director independence is concerned.

\section{Conclusion}

In this article we have expanded the analysis of the new dataset we created in Santella, Paone, Drago (2005) which refers to the population of 284 independent directors who served in 2003 on the boards of the Italian listed companies belonging to the S\&P - MIB Index. The dataset verified to what extent disclosure from Italian listed companies provided a minimum level of information on each independence requirement set by the Preda Code and by the EC Recommendation by assigning three different rates: "yes" (compliance) when company disclosure showed that independent directors satisfied a specific independence requirement; "no" (non-compliance) when company disclosure contradicted a specific independence requirement; and "ns" in case of insufficient company disclosure.

The analysis made in Santella, Paone, Drago (2005) considered our population of 284 Italian independent directors as a single aggregate. In the present paper we move our analysis forward along two lines: we first separate our population in two groups: directors belonging to financial companies' boards and directors belonging to non-financial companies'

${ }^{61}$ As a visual aid we also represent the regression line estimated by ordinary least squares. In particular considering $y=\beta_{1}+\beta_{2} x$ we estimate: $\beta_{2}=\frac{\operatorname{cov}(x, y)}{\operatorname{var}(x)} ; \beta_{1}=\bar{y}-\beta_{2} \bar{x}$ where $\bar{y}$ and $\bar{x}$ are the mean of $y$ and $x$. 
boards; we then move on to aggregate directors according to the companies they belong to, so as to build a dataset of the first 40 Italian listed companies rated according to their disclosure of independence requirements.

We find that independent directors belonging to financial and non-financial companies show a general low level of compliance with both Preda and EC requirements, although directors belonging to non-financial companies show a higher level of compliance with independence requirements compared to directors belonging to financial companies. The main reason for the general low level of compliance for directors belonging to both financial and nonfinancial companies is the very low level of compliance with the two key independence criteria of not having too many concurring commitments outside the company and not having business relationships with the company or an associated company. Such results are confirmed when we aggregate independent directors according to the 40 companies they belong to: overall, both categories have a low level of compliance with EC and Preda criteria and financial companies show a lower level of compliance than nonfinancial ones.

We also find that financial companies are connected with each other and with a few non-financial companies through networks of cross-directorships: two directors (one independent and one executive) who also sit at the same time on another company board. The largest of such networks has at its centre Mediobanca and its two controlling shareholders, Capitalia and Unicredito, with a few non-financial companies at its periphery. Moreover, non-financial companies with higher compliance rates tend not to belong to any network. Third, when non-financial companies establish such strong links as cross-directorship schemes with financial companies they also tend to have a lower level of compliance. We then go on to add to the crossdirectorship networks those links between companies formed through dualdirectorships defined as one independent director who also sits on another company board as independent. The main result is that the Mediobanca network enlarges significantly to include a high proportion of the Italian Blue Chips.

Finally, the analysis at company level identifies that those non-financial companies that have a relatively fragmented shareholder structure (measured by the percentage of total voting shares held by small shareholders who individually hold less than $2 \%$ of the same voting shares) tend to have higher levels of compliance and disclosure (but not always lower levels of not compliance) vis-à-vis tightly-controlled non-financial companies. The explanation we give is that small shareholders are particularly interested in having independent directors on the board to prevent conflicts of interest by management and controlling shareholders and that they need to be relatively numerous compared to controlling shareholders to make themselves heard. Peculiarly, financial companies with fragmented shareholder structure tend to have low disclosure levels, although such companies are also subject to strong financial supervision. 

established by Preda Code and EC Recommendation ${ }^{62}$

Preda Code

- Business Relationships: not having business relationships with the company, its subsidiaries, or its controlling shareholders ${ }^{63}$;

- Other Commitments: not having too many concurring commitments outside the company;

- Family Ties: not satisfying one of the independence requirements indirectly through a close family member;

- Professional Qualification: independent directors are required to be professionally qualified persons;

- Shares Owned: not having a significant amount of shares in the company.

\section{EC Recommendation}

- Business Relationships (enlarged): not having business relationships with the company, its subsidiaries, or its controlling shareholders and not being a member of the executive committee of the company and its associated companies;

- Other Commitments: not having too many concurring commitments outside the company;

- Family Ties: not satisfying one of the independence requirements indirectly through a close family member;

- Professional Qualification: independent directors are required to be professionally qualified persons;

- Permanence on The Board: not having served on the board for more than three terms;

- Additional Remuneration: not receiving significant additional remuneration from the company or an associated company;

- Cross-Directorships: not being part in cross-directorship scheme with another company.

The table enumerates the independence requirements provided by the Preda Code and by the EC Recommendation. Notice that the EC Recommendation provides three more criteria than the Preda Code (Permanence on the Board, Additional Remuneration, CrossDirectorships), while the Preda criterion Shares Owned is not provided by the EC Recommendation.

\footnotetext{
62 For a complete illustration of the independence requirements see Santella, Paone, Drago 2005, in particular Annex B.

${ }^{63}$ Note that this requirement does not exactly correspond to the EC one, the main difference being that EC Business Relationship considers membership of the executive committee as incompatible with board independence.
} 
Table 1A. S\&P-MIB 40 Companies

\begin{tabular}{|c|c|c|}
\hline Company & Label & Single \Multiple-Dual listed (Market) \\
\hline Alleanza Assicurazioni & $\mathrm{Aa}$ & Single \\
\hline Assicurazioni Generali & G & Single \\
\hline Autogrill & $\mathrm{Ag}$ & Single \\
\hline Autostrade & At & Single \\
\hline Banca Antonveneta & An & Single \\
\hline Banca Fideuram & $\mathrm{F}$ & Single \\
\hline Banca Intesa & $\mathrm{I}$ & Single \\
\hline Banca Monte dei Paschi di Siena & $\mathrm{Mp}$ & Single \\
\hline Banca Popolare di Milano & $\mathrm{Bm}$ & Single \\
\hline Banche Popolari Unite & $\mathrm{Pu}$ & Single \\
\hline Banco Popolare di Verona e Novara & $\mathrm{Vn}$ & Single \\
\hline Benetton & $B$ & Single \\
\hline BNL & $\mathrm{NI}$ & Single \\
\hline Bulgari & $\mathrm{Bu}$ & Single \\
\hline Capitalia & $\mathrm{C}$ & Single \\
\hline E.Biscom (Fastweb) & $E$ & Single \\
\hline Edison & Ed & Single \\
\hline Enel & En & Dual (Nyse) \\
\hline ENI & $\mathrm{Ei}$ & Dual (Nyse) \\
\hline Fiat & $\mathrm{Fi}$ & Dual (Nyse) \\
\hline Finmeccanica & $\mathrm{Fm}$ & Single \\
\hline Fondiaria SAI & S & Single \\
\hline Gruppo Editoriale l'Espresso & Es & Single \\
\hline Italcementi & It & Single \\
\hline Luxottica & $\mathrm{L}$ & Dual (Nyse) \\
\hline Mediaset & Md & Single \\
\hline Mediobanca & $\mathrm{Me}$ & Single \\
\hline Mediolanum & $\mathrm{Mm}$ & Single \\
\hline Mondadori & Mo & Single \\
\hline Pirelli \& Co & $\mathrm{P}$ & Single \\
\hline RAS & $\mathrm{R}$ & Single \\
\hline RCS Mediagroup & $\mathrm{Rc}$ & Single \\
\hline San Paolo IMI & $\mathrm{Si}$ & Dual (Nyse) \\
\hline Seat Pagine Gialle & Se & Single \\
\hline Snam Rete Gas & Sn & Single \\
\hline STMicroelectronics & St & Multiple (NyselEuronext Amsterdam) \\
\hline Telecom Italia & $T$ & Dual (Nyse) \\
\hline Telecom Italia Mobile & $\mathrm{Ti}$ & Single \\
\hline Tiscali & Ts & Single \\
\hline Unicredito & $\bar{U}$ & Single \\
\hline
\end{tabular}

The table enumerates the companies that are part of the population examined in the present paper. 
Table 2. General compliance: number of "Yes" rates by company typology (Preda set of criteria)

\begin{tabular}{|c|c|c|c|c|c|c|}
\hline \multicolumn{9}{|c|}{ Preda } \\
\hline & \multicolumn{3}{|c|}{ Not financial } & \multicolumn{3}{c|}{ Financial } \\
\hline Number of yes & Num dir. & Perc. & Cumul. & Num dir. & Perc. & Cumul. \\
\hline 5 & 5 & 4.95 & 4.95 & 0 & 0 & 0 \\
\hline 4 & 9 & 8.91 & 13.86 & 7 & 3.83 & 3.83 \\
\hline 3 & 65 & 64.36 & 78.22 & 130 & 71.04 & 74.87 \\
\hline 2 & 22 & 21.78 & 100 & 45 & 24.59 & 99.46 \\
\hline 1 & 0 & 0 & 100 & 1 & 0.55 & 100 \\
\hline 0 & 0 & 0 & 100 & 0 & 0 & 100 \\
\hline Total & 101 & 100 & & 183 & 100 & \\
\hline
\end{tabular}

With reference to Preda criteria, the table represents the number of compliance ("yes") rates according to company typology. Our population of 284 independent directors is divided in two categories: not financial companies (101 independent directors) and financial companies (183 independent directors).

Table 3. General compliance: number of "Yes" rates by company typology (EC set of criteria)

\begin{tabular}{|c|c|c|c|c|c|c|}
\hline \multicolumn{7}{|c|}{ EC_7 } \\
\hline & \multicolumn{3}{|c|}{ Not financial } & \multicolumn{3}{|c|}{ Financial } \\
\hline Number of yes & Num dir. & Perc. & Cumul. & Num dir. & Perc. & Cumul. \\
\hline 7 & 4 & 3.96 & 3.96 & 0 & 0 & 0 \\
\hline 6 & 8 & 7.92 & 11.88 & 4 & 2.19 & 2.19 \\
\hline 5 & 44 & 43.56 & 55.44 & 48 & 26.23 & 28.42 \\
\hline 4 & 22 & 21.78 & 77.22 & 69 & 37.7 & 66.12 \\
\hline 3 & 20 & 19.8 & 97.02 & 54 & 29.51 & 95.63 \\
\hline 2 & 3 & 2.97 & 100 & 7 & 3.83 & 99.46 \\
\hline 1 & 0 & 0 & 100 & 1 & 0.55 & 100 \\
\hline 0 & 0 & 0 & 100 & 0 & 0 & 100 \\
\hline Total & 101 & 100 & & 183 & 100 & \\
\hline
\end{tabular}

With reference to EC criteria, the table represents the number of compliance ("Yes") rates according to company typology. Our population of 284 independent directors is divided in two categories: not financial companies (101 independent directors) and financial companies (183 independent directors). 
Table 4. Joint distribution of criteria compliance by company tipology (EC and Preda set of criteria)

\begin{tabular}{|c|c|c|c|c|c|c|c|c|}
\hline \multicolumn{9}{|c|}{ Not financial } \\
\hline Preda\EC criteria & 1 & 2 & 3 & 4 & 5 & 6 & 7 & Total \\
\hline 1 & 0 & 0 & 0 & 0 & 0 & 0 & 0 & 0 \\
\hline 2 & 0 & $\begin{array}{c}3 \\
(2.97)\end{array}$ & $\begin{array}{c}14 \\
(13.86)\end{array}$ & $\begin{array}{c}5 \\
(4.95) \\
\end{array}$ & 0 & 0 & 0 & $\begin{array}{c}22 \\
(21.78) \\
\end{array}$ \\
\hline 3 & 0 & 0 & $\begin{array}{c}6 \\
(5.94) \\
\end{array}$ & $\begin{array}{c}17 \\
(16.83) \\
\end{array}$ & $\begin{array}{c}42 \\
(41.58) \\
\end{array}$ & 0 & 0 & $\begin{array}{c}65 \\
(64.36) \\
\end{array}$ \\
\hline 4 & 0 & 0 & 0 & 0 & $\begin{array}{c}2 \\
(1.98)\end{array}$ & $\begin{array}{c}7 \\
(6.93) \\
\end{array}$ & 0 & $\begin{array}{c}9 \\
(8.91)\end{array}$ \\
\hline 5 & 0 & 0 & 0 & 0 & 0 & $\begin{array}{c}1 \\
(0.99)\end{array}$ & $\begin{array}{c}4 \\
(3.96)\end{array}$ & $\begin{array}{c}5 \\
(4.95)\end{array}$ \\
\hline Total & 0 & $\begin{array}{c}3 \\
(2.97) \\
\end{array}$ & $\begin{array}{c}20 \\
(19.80) \\
\end{array}$ & $\begin{array}{c}22 \\
(21.78) \\
\end{array}$ & $\begin{array}{c}44 \\
(43.56) \\
\end{array}$ & $\begin{array}{c}8 \\
(7.92) \\
\end{array}$ & $\begin{array}{c}4 \\
(3.96) \\
\end{array}$ & $\begin{array}{c}101 \\
(100)\end{array}$ \\
\hline \multicolumn{9}{|c|}{ Financial } \\
\hline & & & & & & & & \\
\hline Preda\EC criteria & 1 & 2 & 3 & 4 & 5 & 6 & 7 & Total \\
\hline 1 & 0 & 0 & $\begin{array}{c}1 \\
(0.55)\end{array}$ & 0 & 0 & 0 & 0 & $\begin{array}{c}1 \\
(0.55)\end{array}$ \\
\hline 2 & $\begin{array}{c}1 \\
(0.55) \\
\end{array}$ & $\begin{array}{c}3 \\
(1.64)\end{array}$ & $\begin{array}{c}17 \\
(9.29) \\
\end{array}$ & $\begin{array}{c}23 \\
(12.57) \\
\end{array}$ & $\begin{array}{c}1 \\
(0.55) \\
\end{array}$ & 0 & 0 & $\begin{array}{c}45 \\
(24.59) \\
\end{array}$ \\
\hline 3 & 0 & $\begin{array}{c}4 \\
(2.19)\end{array}$ & $\begin{array}{c}36 \\
(19.67) \\
\end{array}$ & $\begin{array}{c}45 \\
(24.59) \\
\end{array}$ & $\begin{array}{c}45 \\
(24.59)\end{array}$ & 0 & 0 & $\begin{array}{c}130 \\
(71.04)\end{array}$ \\
\hline 4 & 0 & 0 & 0 & $\begin{array}{c}1 \\
(0.55) \\
\end{array}$ & $\begin{array}{c}2 \\
(1.09) \\
\end{array}$ & $\begin{array}{c}4 \\
(2.19) \\
\end{array}$ & 0 & $\begin{array}{c}7 \\
(3.83) \\
\end{array}$ \\
\hline 5 & 0 & 0 & 0 & 0 & 0 & 0 & 0 & 0 \\
\hline Total & $\begin{array}{c}1 \\
(0.55)\end{array}$ & $\begin{array}{c}7 \\
(3.83)\end{array}$ & $\begin{array}{c}54 \\
(29.51)\end{array}$ & $\begin{array}{c}69 \\
(37.70)\end{array}$ & $\begin{array}{c}48 \\
(26.23)\end{array}$ & $\begin{array}{c}4 \\
(2.19)\end{array}$ & 0 & $\begin{array}{c}183 \\
(100)\end{array}$ \\
\hline
\end{tabular}

The table represents separately for financial and not financial companies the number of independent directors who show compliance with EC and Preda criteria. Percentages in brackets. 
Table 5. Marginal distribution of criteria by company typology

Preda and EC criteria

\begin{tabular}{|c|c|c|c|c|c|c|c|}
\hline & & \multicolumn{2}{|c|}{ Not financial } & & \multicolumn{2}{|c|}{ Financial } & \multirow[b]{2}{*}{ Cumul. } \\
\hline & & Freq. & Perc. & Cumul. & Freq. & Perc. & \\
\hline \multirow{4}{*}{$\begin{array}{c}\text { Business Relationships } \\
\text { (Preda) }\end{array}$} & no & 16 & 15.84 & 15.84 & 15 & 8.20 & 8.20 \\
\hline & ns & 76 & 75.25 & 91.09 & 168 & 91.80 & 100 \\
\hline & yes & 9 & 8.91 & 100 & 0 & 0 & 100 \\
\hline & total & 101 & 100 & & 183 & 1.00 & \\
\hline \multirow{5}{*}{ Shares Owned (Preda) } & & & & & & & \\
\hline & no & 0 & 0 & 0 & 2 & 1.09 & 1.09 \\
\hline & ns & 0 & 0 & 0 & 0 & 0 & 1.09 \\
\hline & yes & 101 & 100 & 100 & 181 & 98.91 & 100 \\
\hline & total & 101 & 100 & & 183 & 1.00 & \\
\hline \multirow{4}{*}{ Family Ties (Preda and EC) } & no & 0 & 0 & 0 & 0 & 0 & 0 \\
\hline & ns & 25 & 24.75 & 24.75 & 46 & 25.15 & 25.15 \\
\hline & yes & 76 & 75.25 & 100 & 137 & 74.86 & 100 \\
\hline & total & 101 & 100 & & 183 & 100 & \\
\hline \multirow{5}{*}{$\begin{array}{l}\text { Professional Qualification } \\
\text { (Preda and EC) }\end{array}$} & & & & & & & \\
\hline & no & 1 & 0.99 & 0.99 & 0 & 0.00 & 0.00 \\
\hline & ns & 9 & 8.91 & 9.90 & 16 & 8.74 & 8.74 \\
\hline & yes & 91 & 90.10 & 100 & 167 & 91.26 & 100 \\
\hline & total & 101 & 100 & & 183 & 100 & \\
\hline \multirow{5}{*}{$\begin{array}{l}\text { Other Commitments } \\
\text { (Preda and EC) }\end{array}$} & & ca & $65 ? 5$ & c5 25 & & & \\
\hline & no & 66 & 65.35 & 65.35 & 130 & 71.04 & 71.04 \\
\hline & ns & 12 & 11.88 & 77.23 & 29 & 15.85 & 86.89 \\
\hline & yes & 23 & 22.77 & 100 & 24 & 13.11 & 100 \\
\hline & total & 101 & 100 & & 183 & 100 & \\
\hline
\end{tabular}

Additional EC Criteria

\begin{tabular}{|c|c|c|c|c|c|c|c|}
\hline & & \multicolumn{3}{|c|}{ Not financial } & \multicolumn{3}{c|}{ Financial } \\
\hline & & Freq. & Perc. & Cumul. & Freq. & Perc. & Cumul. \\
\hline \multirow{3}{*}{ EC_Business Rel. enlarged } & No & 17 & 16.83 & 16.83 & 79 & 43.17 & 43.17 \\
\cline { 2 - 9 } & Ns & 75 & 74.26 & 91.09 & 104 & 56.83 & 100 \\
\cline { 2 - 9 } & Yes & 9 & 8.91 & 100 & 0 & 0 & 100 \\
\cline { 2 - 9 } & Total & 101 & 100 & & 183 & 100 & \\
\hline \multirow{4}{*}{ Additional Remuneration } & No & 14 & 13.86 & 13.86 & 23 & 12.57 & 12.57 \\
\cline { 2 - 9 } & Ns & 5 & 4.95 & 18.81 & 35 & 19.13 & 31.69 \\
\cline { 2 - 8 } & Yes & 82 & 81.19 & 100 & 125 & 68.31 & 100 \\
\cline { 2 - 8 } & Total & 101 & 100 & & 183 & 100 & \\
\hline \multirow{6}{*}{ Cross-Directorships } & No & 5 & 4.95 & 4.95 & 27 & 14.75 & 14.75 \\
\cline { 2 - 8 } & Ns & 0 & 0 & 4.95 & 0 & 0 & 14.75 \\
\cline { 2 - 8 } & Yes & 96 & 95.05 & 100 & 156 & 85.25 & 100 \\
\cline { 2 - 8 } & Total & 101 & 100 & & 183 & 100 & \\
\hline Permanence on the Board & No & 9 & 8.91 & 8.91 & 15 & 8.20 & 8.20 \\
\cline { 2 - 8 } & Ns & 19 & 18.81 & 27.72 & 60 & 32.79 & 40.98 \\
\cline { 2 - 8 } & yes & 73 & 72.28 & 100 & 108 & 59.02 & 100 \\
\cline { 2 - 7 } & total & 101 & 100 & & 183 & 100 & \\
\hline
\end{tabular}


With reference to each EC and Preda criterion, the table represents the number of compliance ("Yes") rates according to company typology. Our population of 284 independent directors is divided in two categories: not financial companies (101 independent directors) and financial companies (183 independent directors).

Table 5.1 Comparative compliance with Preda and EC Business Relationships and Other Commitments

Total (Financial+Not financial companies)

\begin{tabular}{|l|c|c|c|c|}
\hline \multicolumn{7}{|c|}{ Preda } \\
\hline Preda Business R./Other C. & No & Ns & Yes & Total \\
\hline No & 24 & 2 & 5 & 31 \\
& $(8.45)$ & $(0.70)$ & $(1.76)$ & $(10.92)$ \\
\hline Ns & 169 & 39 & 36 & 244 \\
& $(59.51)$ & $(13.73)$ & $(12.68)$ & $(85.92)$ \\
\hline Yes & 3 & 0 & 6 & 9 \\
& $(1.06)$ & & $(2.11)$ & $(3.17)$ \\
\hline Total & 196 & 41 & 47 & 284 \\
& $(69.01)$ & $(14.44)$ & $(16.55)$ & $(100)$ \\
\hline
\end{tabular}

\begin{tabular}{|c|c|c|c|c|}
\hline \multicolumn{5}{|c|}{ EC } \\
\hline EC_Business R. enlarged/Other C. & No & Ns & Yes & Total \\
\hline No & $\begin{array}{c}78 \\
(27.46)\end{array}$ & $\begin{array}{c}8 \\
(2.82)\end{array}$ & $\begin{array}{c}10 \\
(3.52)\end{array}$ & $\begin{array}{c}96 \\
(33.80)\end{array}$ \\
\hline Ns & $\begin{array}{c}115 \\
(40.49)\end{array}$ & $\begin{array}{c}33 \\
(11.62)\end{array}$ & $\begin{array}{c}31 \\
(10.92)\end{array}$ & $\begin{array}{c}179 \\
(63.03)\end{array}$ \\
\hline Yes & $\begin{array}{c}3 \\
(1.06)\end{array}$ & 0 & $\begin{array}{c}6 \\
(2.11)\end{array}$ & $\begin{array}{c}9 \\
(3.17)\end{array}$ \\
\hline Total & $\begin{array}{c}196 \\
(69.01)\end{array}$ & $\begin{array}{c}41 \\
(14.44)\end{array}$ & $\begin{array}{c}47 \\
(16.55)\end{array}$ & $\begin{array}{c}284 \\
(100)\end{array}$ \\
\hline
\end{tabular}

The Table represents the number of independent directors who show compliance ("yes"), not compliance ("no") and not disclosure ("ns") at the same time with two couples of criteria: Preda Business Relationships/Other Commitments and EC Business Relationships/Other Commitments. Percentages are in brackets. Such criteria are responsible in the first place for the general low compliance level of our population with all 5 Preda and 7 EC independence criteria. Besides, such criteria are also those more easily verifiable. 
Table 5.2 Comparative compliance with Preda and EC Business Relationships and Other Commitments

\begin{tabular}{|c|c|c|c|c|}
\hline \multicolumn{5}{|c|}{ Financial/not Financial Preda } \\
\hline \multicolumn{5}{|l|}{ Not financial } \\
\hline Preda Business R.IOther C. & No & Ns & Yes & Total \\
\hline No & $\begin{array}{c}10 \\
(9.90)\end{array}$ & $\begin{array}{c}2 \\
(1.98)\end{array}$ & $\begin{array}{c}4 \\
(3.96)\end{array}$ & $\begin{array}{c}16 \\
(15.84)\end{array}$ \\
\hline Ns & $\begin{array}{c}53 \\
(52.48)\end{array}$ & $\begin{array}{c}10 \\
(9.90)\end{array}$ & $\begin{array}{c}13 \\
(12.87)\end{array}$ & $\begin{array}{c}76 \\
(75.25)\end{array}$ \\
\hline Yes & $\begin{array}{c}3 \\
(2.97)\end{array}$ & 0 & $\begin{array}{c}6 \\
(5.94)\end{array}$ & $\begin{array}{c}9 \\
(8.91)\end{array}$ \\
\hline Total & $\begin{array}{c}66 \\
(65.35)\end{array}$ & $\begin{array}{c}12 \\
(11.88)\end{array}$ & $\begin{array}{c}23 \\
(22.77)\end{array}$ & $\begin{array}{c}101 \\
(100)\end{array}$ \\
\hline \multicolumn{5}{|l|}{ Financial } \\
\hline Preda Business R. IOther C. & No & Ns & Yes & Total \\
\hline No & $\begin{array}{c}14 \\
(7.65)\end{array}$ & 0 & $\begin{array}{c}1 \\
(0.55)\end{array}$ & $\begin{array}{c}15 \\
(8.20)\end{array}$ \\
\hline Ns & $\begin{array}{c}116 \\
(63.39)\end{array}$ & $\begin{array}{c}29 \\
(15.85)\end{array}$ & $\begin{array}{c}23 \\
(12.57)\end{array}$ & $\begin{array}{c}168 \\
(91.80)\end{array}$ \\
\hline Yes & 0 & 0 & 0 & 0 \\
\hline Total & $\begin{array}{c}130 \\
(71.04)\end{array}$ & $\begin{array}{c}29 \\
(15.85)\end{array}$ & $\begin{array}{c}24 \\
(13.11)\end{array}$ & $\begin{array}{c}183 \\
(100)\end{array}$ \\
\hline
\end{tabular}

\begin{tabular}{|c|c|c|c|c|}
\hline \multicolumn{5}{|c|}{ Financial/not Financial EC } \\
\hline Not financial & & & & \\
\hline EC Business R. enlarged $\backslash$ Other C. & No & Ns & Yes & Total \\
\hline No & $\begin{array}{c}11 \\
(10.89)\end{array}$ & $\begin{array}{c}2 \\
(1.98)\end{array}$ & $\begin{array}{c}4 \\
(3.96)\end{array}$ & $\begin{array}{c}17 \\
(16.83)\end{array}$ \\
\hline Ns & $\begin{array}{c}52 \\
(51.49)\end{array}$ & $\begin{array}{c}10 \\
(9.90)\end{array}$ & $\begin{array}{c}13 \\
(12.87)\end{array}$ & $\begin{array}{c}75 \\
(74.26)\end{array}$ \\
\hline Yes & $\begin{array}{c}3 \\
(2.97) \\
\end{array}$ & 0 & $\begin{array}{c}6 \\
(5.94) \\
\end{array}$ & $\begin{array}{c}9 \\
(8.91) \\
\end{array}$ \\
\hline Total & $\begin{array}{c}66 \\
(65.35)\end{array}$ & $\begin{array}{c}12 \\
(11.88)\end{array}$ & $\begin{array}{c}23 \\
(22.77)\end{array}$ & $\begin{array}{c}101 \\
(100)\end{array}$ \\
\hline Financial & & & & \\
\hline EC Business R. enlarged $\backslash$ Other $C$. & No & Ns & Yes & Total \\
\hline No & $\begin{array}{c}67 \\
(36.61)\end{array}$ & $\begin{array}{c}6 \\
(3.28)\end{array}$ & $\begin{array}{c}6 \\
(3.28)\end{array}$ & $\begin{array}{c}79 \\
(43.17)\end{array}$ \\
\hline Ns & $\begin{array}{c}63 \\
(34.43) \\
\end{array}$ & $\begin{array}{c}23 \\
(12.57) \\
\end{array}$ & $\begin{array}{c}18 \\
(9.84) \\
\end{array}$ & $\begin{array}{c}104 \\
(56.83) \\
\end{array}$ \\
\hline Yes & 0 & 0 & 0 & 0 \\
\hline Total & $\begin{array}{c}130 \\
(71.04) \\
\end{array}$ & $\begin{array}{c}29 \\
(15.85) \\
\end{array}$ & $\begin{array}{c}24 \\
(13.11) \\
\end{array}$ & $\begin{array}{c}183 \\
(100) \\
\end{array}$ \\
\hline
\end{tabular}

The Table represents the number of independent directors who show compliance ("yes"), not compliance ("no") and not disclosure ("ns") at the same time with two couples of criteria: Preda Business Relationships/Other Commitments and EC Business Relationships/Other Commitments. Percentages are in brackets. With respect to Table 5.1, in this case the results are split according to company typology (financial and not financial companies). 
Table 6. Scatter diagram on compliance and not disclosure rates: EC

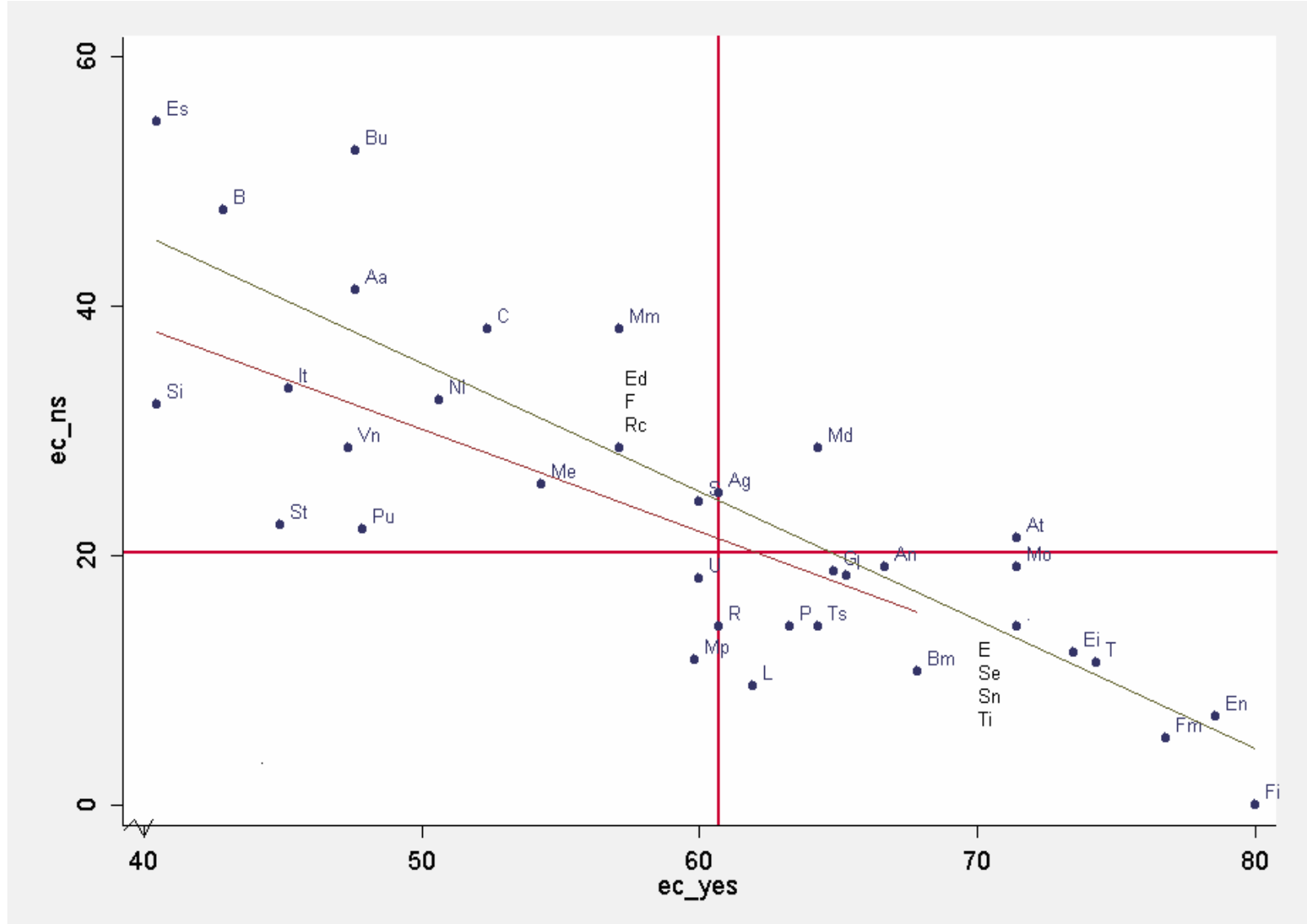

Each dot represents one company, all 40 companies are considered. See Table 1A for the labels. As a visual aid, the table also depicts two regression lines estimated by ordinary least squares separately for financial and not financial companies (green for not financial and red for financial). The two orthogonal red lines identify the $50^{\text {th }}$ percentile for each global rate (ec_ns and ec_yes). To improve the data visualization some of the scale values are omitted. 
Table 7. Scatter diagram on compliance and not disclosure rates: Preda

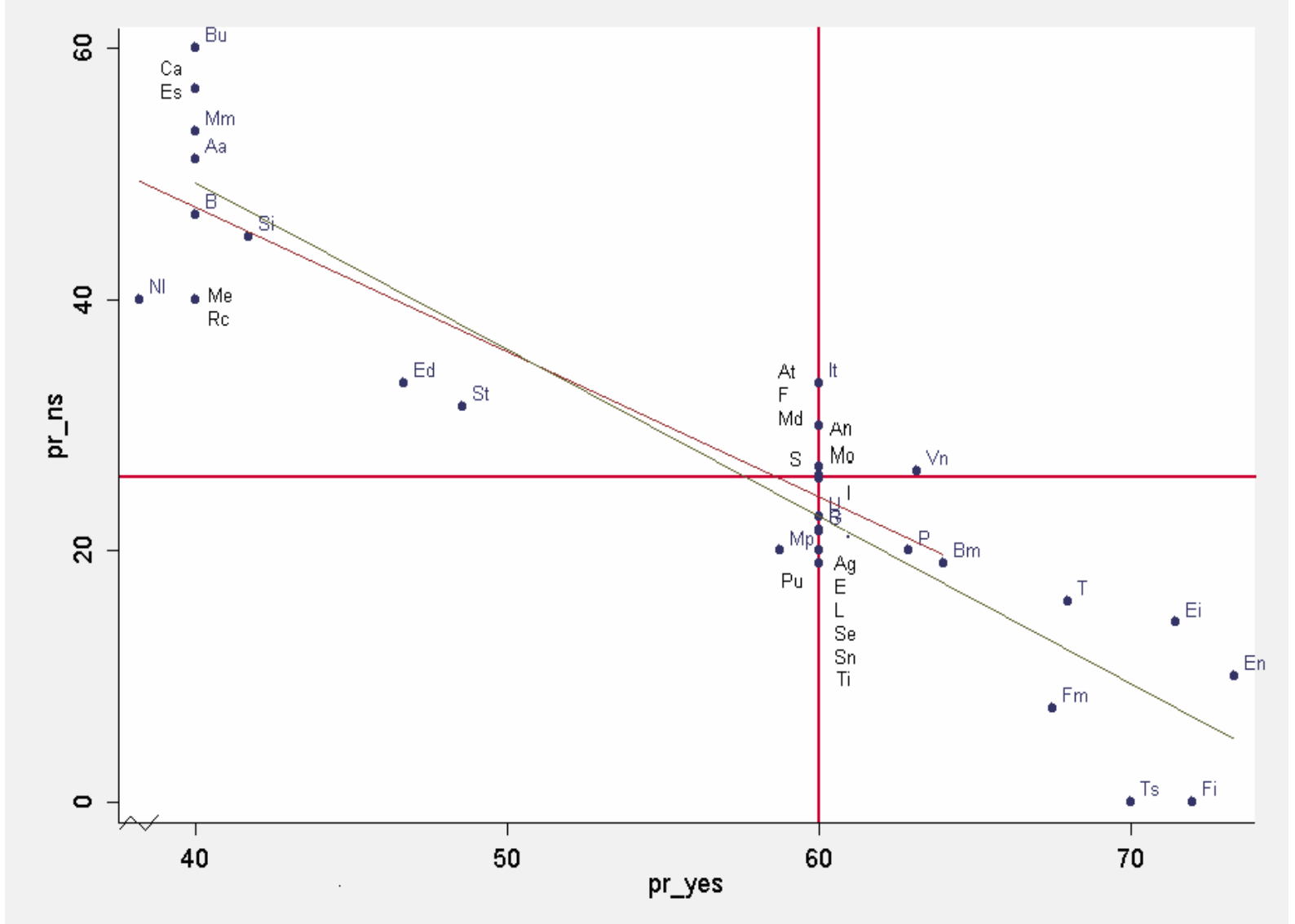

Each dot represents one company, all 40 companies considered. See Table 1A for the labels. As a visual aid, the table also depicts two regression lines estimated by ordinary least squares separately for financial and not financial companies (green for not financial and red for financial). The two orthogonal red lines identify the $50^{\text {th }}$ percentile for each global rate (preda_ns and preda_yes). To improve the data visualization some of the scale values are omitted. 
Table 8. Global rates EC/Preda by company

\begin{tabular}{|c|c|c|c|c|c|c|c|c|c|}
\hline & \multicolumn{3}{|c|}{ EC } & \multicolumn{3}{|c|}{ Preda } & \multicolumn{3}{|c|}{ Differences EC-Preda } \\
\hline Company & ec_yes & ec_no & ec_ns & pr_yes & pr_no & pr_ns & diff.yes & diff.no & diff.ns \\
\hline Alleanza Assicurazioni & 47.62 & 11.11 & 41.27 & 40 & 8.89 & 51.11 & 7.62 & 2.22 & -9.84 \\
\hline Assicurazioni Generali & 64.84 & 16.48 & 18.68 & 60 & 18.46 & 21.54 & 4.84 & -1.98 & -2.86 \\
\hline Autogrill & 60.71 & 14.29 & 25 & 60 & 20 & 20 & 0.71 & -5.71 & 5 \\
\hline Autostrade & 71.43 & 7.14 & 21.43 & 60 & 10 & 30 & 11.43 & -2.86 & -8.57 \\
\hline Banca Antonveneta & 66.67 & 14.29 & 19.05 & 60 & 13.33 & 26.67 & 6.67 & 0.95 & -7.62 \\
\hline Banca Fideuram & 57.14 & 14.29 & 28.57 & 60 & 10 & 30 & -2.86 & 4.29 & -1.43 \\
\hline Banca Intesa & 65.31 & 16.33 & 18.37 & 60 & 14.29 & 25.71 & 5.31 & 2.04 & -7.35 \\
\hline Banca Monte dei Paschi di Siena & 59.82 & 28.57 & 11.61 & 58.75 & 21.25 & 20 & 1.07 & 7.32 & -8.39 \\
\hline Banca Popolare di Milano & 67.86 & 21.43 & 10.71 & 64 & 17 & 19 & 3.86 & 4.43 & -8.29 \\
\hline Banche Popolari Unite & 47.86 & 30 & 22.14 & 60 & 21 & 19 & -12.14 & 9 & 3.14 \\
\hline Banco Popolare di Verona e Novara & 47.37 & 24.06 & 28.57 & 63.16 & 10.53 & 26.32 & -15.79 & 13.53 & 2.26 \\
\hline Benetton & 42.86 & 9.52 & 47.62 & 40 & 13.33 & 46.67 & 2.86 & -3.81 & 0.95 \\
\hline BNL & 50.65 & 16.88 & 32.47 & 38.18 & 21.82 & 40 & 12.47 & -4.94 & -7.53 \\
\hline Bulgari & 47.62 & 0 & 52.38 & 40 & 0 & 60 & 7.62 & 0 & -7.62 \\
\hline Capitalia & 52.38 & 9.52 & 38.1 & 40 & 3.33 & 56.67 & 12.38 & 6.19 & -18.57 \\
\hline E.Biscom (Fastweb) & 71.43 & 14.29 & 14.29 & 60 & 20 & 20 & 11.43 & -5.71 & -5.71 \\
\hline Edison & 57.14 & 14.29 & 28.57 & 46.67 & 20 & 33.33 & 10.48 & -5.71 & -4.76 \\
\hline Enel & 78.57 & 14.29 & 7.14 & 73.33 & 16.67 & 10 & 5.24 & -2.38 & -2.86 \\
\hline ENI & 73.47 & 14.29 & 12.25 & 71.43 & 14.29 & 14.29 & 2.04 & 0 & -2.04 \\
\hline Fiat & 80 & 20 & 0 & 72 & 28 & 0 & 8 & -8 & 0 \\
\hline Finmeccanica & 76.79 & 17.86 & 5.36 & 67.5 & 25 & 7.5 & 9.29 & -7.14 & -2.14 \\
\hline Fondiaria SAI & 60 & 15.71 & 24.29 & 60 & 14 & 26 & 0 & 1.71 & -1.71 \\
\hline Gruppo Editoriale l'Espresso & 40.48 & 4.76 & 54.76 & 40 & 3.33 & 56.67 & 0.48 & 1.43 & -1.91 \\
\hline Italcementi & 45.24 & 21.43 & 33.33 & 60 & 6.67 & 33.33 & -14.76 & 14.76 & 0 \\
\hline Luxottica & 61.9 & 28.57 & 9.52 & 60 & 20 & 20 & 1.9 & 8.57 & -10.48 \\
\hline Mediaset & 64.29 & 7.14 & 28.57 & 60 & 10 & 30 & 4.29 & -2.86 & -1.43 \\
\hline Mediobanca & 54.29 & 20 & 25.71 & 40 & 20 & 40 & 14.29 & 0 & -14.29 \\
\hline Mediolanum & 57.14 & 4.76 & 38.1 & 40 & 6.67 & 53.33 & 17.14 & -1.91 & -15.24 \\
\hline Mondadori & 71.43 & 9.52 & 19.05 & 60 & 13.33 & 26.67 & 11.43 & -3.81 & -7.62 \\
\hline Pirelli \& Co & 63.27 & 22.45 & 14.29 & 62.86 & 17.14 & 20 & 0.41 & 5.31 & -5.71 \\
\hline RAS & 60.71 & 25 & 14.29 & 60 & 18.33 & 21.67 & 0.71 & 6.67 & -7.38 \\
\hline RCS Mediagroup & 57.14 & 14.29 & 28.57 & 40 & 20 & 40 & 17.14 & -5.71 & -11.43 \\
\hline San Paolo IMI & 40.48 & 27.38 & 32.14 & 41.67 & 13.33 & 45 & -1.19 & 14.05 & -12.86 \\
\hline Seat Pagine Gialle & 71.43 & 14.29 & 14.29 & 60 & 20 & 20 & 11.43 & -5.71 & -5.71 \\
\hline Snam Rete Gas & 71.43 & 14.29 & 14.29 & 60 & 20 & 20 & 11.43 & -5.71 & -5.71 \\
\hline STMicroelectronics & 44.9 & 32.65 & 22.45 & 48.57 & 20 & 31.43 & -3.67 & 12.65 & -8.98 \\
\hline Telecom Italia & 74.29 & 14.29 & 11.43 & 68 & 16 & 16 & 6.29 & -1.71 & -4.57 \\
\hline Telecom Italia Mobile & 71.43 & 14.29 & 14.29 & 60 & 20 & 20 & 11.43 & -5.71 & -5.71 \\
\hline Tiscali & 64.29 & 21.43 & 14.29 & 70 & 30 & 0 & -5.71 & -8.57 & 14.29 \\
\hline Unicredito & 60 & 21.91 & 18.1 & 60 & 17.33 & 22.67 & 0 & 4.57 & -4.57 \\
\hline
\end{tabular}

See equation (6) Results of the original rates are multiplied by 100. 
Table 8.1 Comparative company rankings by EC/Preda global rates

\begin{tabular}{|c|c|c|c|c|c|c|}
\hline Company & ec_yes & ec_no & ec_ns & pr_yes & pr_no & pr_ns \\
\hline Alleanza Assicurazioni & 33 & 9 & 37 & 32 & 6 & 36 \\
\hline Assicurazioni Generali & 15 & 24 & 18 & 10 & 24 & 17 \\
\hline Autogrill & 20 & 10 & 25 & 10 & 25 & 9 \\
\hline Autostrade & 6 & 4 & 21 & 10 & 7 & 25 \\
\hline Banca Antonveneta & 13 & 10 & 19 & 10 & 11 & 23 \\
\hline Banca Fideuram & 25 & 10 & 27 & 10 & 7 & 25 \\
\hline Banca Intesa & 14 & 23 & 17 & 10 & 16 & 20 \\
\hline Banca Monte dei Paschi di Siena & 24 & 37 & 7 & 28 & 36 & 9 \\
\hline Banca Popolare di Milano & 12 & 29 & 5 & 7 & 20 & 7 \\
\hline Banche Popolari Unite & 32 & 39 & 22 & 10 & 35 & 7 \\
\hline Banco Popolare di Verona e Novara & 35 & 34 & 27 & 8 & 10 & 22 \\
\hline Benetton & 38 & 6 & 38 & 32 & 11 & 35 \\
\hline$\overline{\mathrm{BNL}}$ & 31 & 25 & 33 & 40 & 37 & 31 \\
\hline Bulgari & 33 & 1 & 39 & 32 & 1 & 40 \\
\hline Capitalia & 30 & 6 & 35 & 32 & 2 & 38 \\
\hline E.Biscom (Fastweb) & 6 & 10 & 9 & 10 & 25 & 9 \\
\hline Edison & 25 & 10 & 27 & 30 & 25 & 29 \\
\hline Enel & 2 & 10 & 3 & 1 & 19 & 4 \\
\hline ENI & 5 & 10 & 8 & 3 & 16 & 5 \\
\hline Fiat & 1 & 27 & 1 & 2 & 39 & 1 \\
\hline Finmeccanica & 3 & 26 & 2 & 6 & 38 & 3 \\
\hline Fondiaria SAI & 22 & 22 & 24 & 10 & 15 & 21 \\
\hline Gruppo Editoriale l'Espresso & 39 & 2 & 40 & 32 & 2 & 38 \\
\hline Italcementi & 36 & 29 & 34 & 10 & 4 & 29 \\
\hline Luxottica & 19 & 37 & 4 & 10 & 25 & 9 \\
\hline Mediaset & 16 & 4 & 27 & 10 & 7 & 25 \\
\hline Mediobanca & 29 & 27 & 26 & 32 & 25 & 31 \\
\hline Mediolanum & 25 & 2 & 35 & 32 & 4 & 37 \\
\hline Mondadori & 6 & 6 & 19 & 10 & 11 & 23 \\
\hline Pirelli \& Co & 18 & 33 & 9 & 9 & 21 & 9 \\
\hline RAS & 20 & 35 & 9 & 10 & 23 & 18 \\
\hline RCS Mediagroup & 25 & 10 & 27 & 32 & 25 & 31 \\
\hline San Paolo IMI & 39 & 36 & 32 & 31 & 11 & 34 \\
\hline Seat Pagine Gialle & 6 & 10 & 9 & 10 & 25 & 9 \\
\hline Snam Rete Gas & 6 & 10 & 9 & 10 & 25 & 9 \\
\hline STMicroelectronics & 37 & 40 & 23 & 29 & 25 & 28 \\
\hline Telecom Italia & 4 & 10 & 6 & 5 & 18 & 6 \\
\hline Telecom Italia Mobile & 6 & 10 & 9 & 10 & 25 & 9 \\
\hline Tiscali & 16 & 29 & 9 & 4 & 40 & 1 \\
\hline Unicredito & 22 & 32 & 16 & 10 & 22 & 19 \\
\hline
\end{tabular}

The Table represents the company profiles for the 40 companies considered in this paper. Each profile is given by the six rankings referring to the six global rates. Each ranking is done by sorting from the maximum to the minimum value and assigning the highest possible rank whenever two or more companies are characterized by an equal global rate. 
Table 8.2 Comparative scores by EC/Preda global rates (max S \& $\mathrm{P}$ MIB=100)

\begin{tabular}{|c|c|c|c|c|c|c|}
\hline Company & ec_yes & ec_no & ec_ns & pr_yes & pr_no & pr_ns \\
\hline Alleanza Assicurazioni & 60 & 34 & 75 & 55 & 30 & 85 \\
\hline Assicurazioni Generali & 81 & 50 & 34 & 82 & 62 & 36 \\
\hline Autogrill & 76 & 44 & 46 & 82 & 67 & 33 \\
\hline Autostrade & 89 & 22 & 39 & 82 & 33 & 50 \\
\hline Banca Antonveneta & 83 & 44 & 35 & 82 & 44 & 44 \\
\hline Banca Fideuram & 71 & 44 & 52 & 82 & 33 & 50 \\
\hline Banca Intesa & 82 & 50 & 34 & 82 & 48 & 43 \\
\hline Banca Monte dei Paschi di Siena & 75 & 88 & 21 & 80 & 71 & 33 \\
\hline Banca Popolare di Milano & 85 & 66 & 20 & 87 & 57 & 32 \\
\hline Banche Popolari Unite & 60 & 92 & 40 & 82 & 70 & 32 \\
\hline Banco Popolare di Verona e Novara & 59 & 74 & 52 & 86 & 35 & 44 \\
\hline Benetton & 54 & 29 & 87 & 55 & 44 & 78 \\
\hline$\overline{B N L}$ & 63 & 52 & 59 & 52 & 73 & 67 \\
\hline Bulgari & 60 & 0 & 96 & 55 & 0 & 100 \\
\hline Capitalia & 65 & 29 & 70 & 55 & 11 & 94 \\
\hline E.Biscom (Fastweb) & 89 & 44 & 26 & 82 & 67 & 33 \\
\hline Edison & 71 & 44 & 52 & 64 & 67 & 56 \\
\hline Enel & 98 & 44 & 13 & 100 & 56 & 17 \\
\hline ENI & 92 & 44 & 22 & 97 & 48 & 24 \\
\hline Fiat & 100 & 61 & 0 & 98 & 93 & 0 \\
\hline Finmeccanica & 96 & 55 & 10 & 92 & 83 & 13 \\
\hline Fondiaria SAI & 75 & 48 & 44 & 82 & 47 & 43 \\
\hline Gruppo Editoriale l'Espresso & 51 & 15 & 100 & 55 & 11 & 94 \\
\hline Italcementi & 57 & 66 & 61 & 82 & 22 & 56 \\
\hline Luxottica & 77 & 88 & 17 & 82 & 67 & 33 \\
\hline Mediaset & 80 & 22 & 52 & 82 & 33 & 50 \\
\hline Mediobanca & 68 & 61 & 47 & 55 & 67 & 67 \\
\hline Mediolanum & 71 & 15 & 70 & 55 & 22 & 89 \\
\hline Mondadori & 89 & 29 & 35 & 82 & 44 & 44 \\
\hline Pirelli \& Co & 79 & 69 & 26 & 86 & 57 & 33 \\
\hline RAS & 76 & 77 & 26 & 82 & 61 & 36 \\
\hline RCS Mediagroup & 71 & 44 & 52 & 55 & 67 & 67 \\
\hline San Paolo IMI & 51 & 84 & 59 & 57 & 44 & 75 \\
\hline Seat Pagine Gialle & 89 & 44 & 26 & 82 & 67 & 33 \\
\hline Snam Rete Gas & 89 & 44 & 26 & 82 & 67 & 33 \\
\hline STMicroelectronics & 56 & 100 & 41 & 66 & 67 & 52 \\
\hline Telecom Italia & 93 & 44 & 21 & 93 & 53 & 27 \\
\hline Telecom Italia Mobile & 89 & 44 & 26 & 82 & 67 & 33 \\
\hline Tiscali & 80 & 66 & 26 & 95 & 100 & 0 \\
\hline Unicredito & 75 & 67 & 33 & 82 & 58 & 38 \\
\hline
\end{tabular}

The Table represents company scores obtained by assigning the value 100 to the maximum global company rate as represented in Table 8 . The other scores are attributed as a fraction (multiplied by 100) of the specific global company rate over the maximum global company rate. Tables $8,8.1$, and 8.2 should be considered as complementary. 
Table 9. Joint compliance rates (Preda and EC)

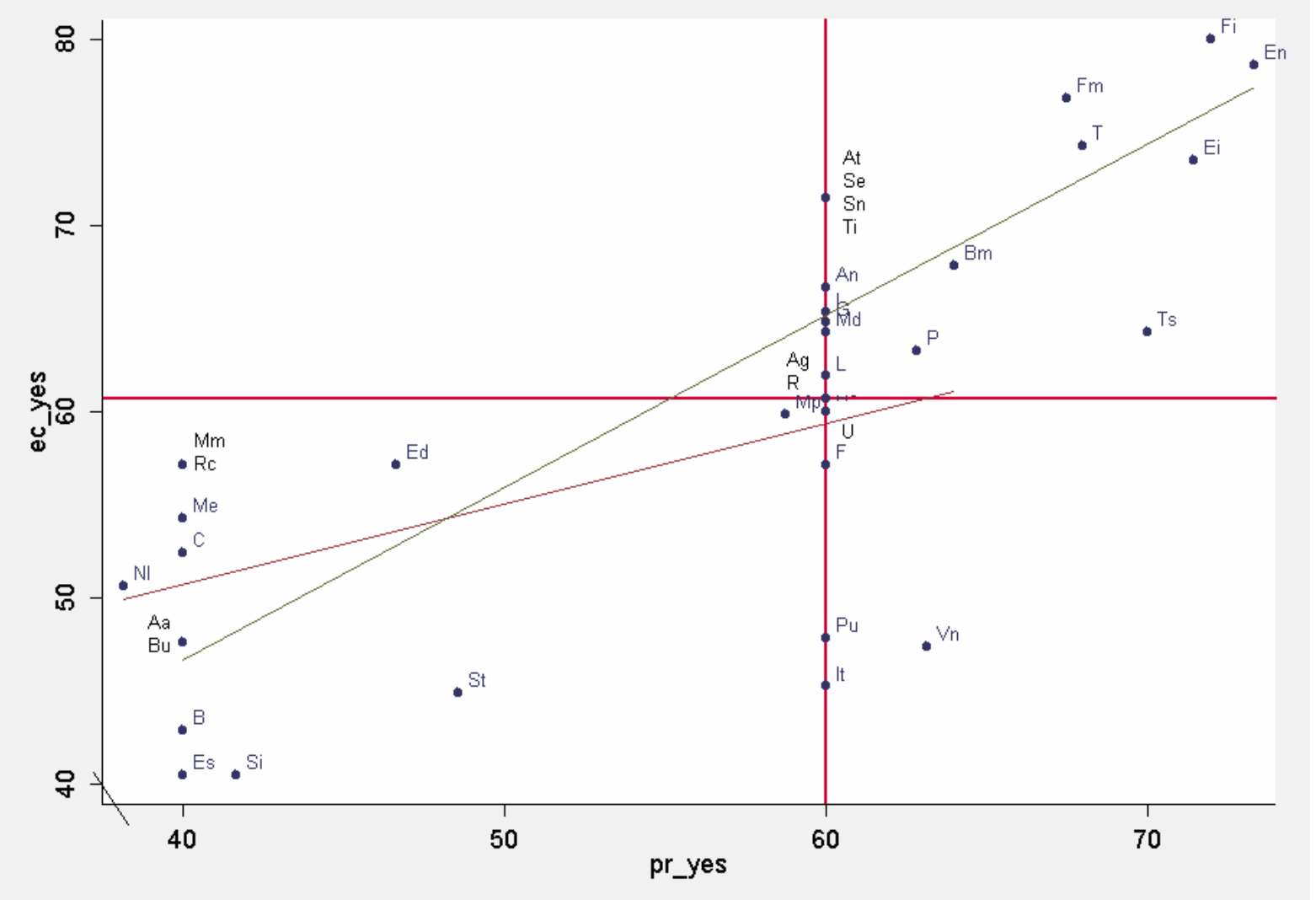

Each dot represents one company, all 40 companies are considered. See Table 1A for the labels. As a visual aid, the table also depicts two regression lines estimated by ordinary least squares separately for financial and not financial companies (green for not financial and red for financial). The two orthogonal red lines identify the $50^{\text {th }}$ percentile for each global rate (EC_yes and preda_yes). To improve the data visualization some of the scale values are omitted. 
Table 10. Comparative company rankings by independence criteria

\begin{tabular}{|c|c|c|c|c|c|c|c|c|c|}
\hline Company & $\begin{array}{l}\text { Bus.Rel. } \\
\text { (Preda) }\end{array}$ & $\begin{array}{l}\text { Shares } \\
\text { Owned } \\
\text { (Preda) }\end{array}$ & $\begin{array}{l}\text { Family } \\
\text { Ties } \\
\text { (EC|Preda) }\end{array}$ & $\begin{array}{l}\text { Profess. } \\
\text { Qualif. } \\
\text { (EC\Preda) }\end{array}$ & $\begin{array}{l}\text { Other } \\
\text { Comm. } \\
\text { (EC\Preda) }\end{array}$ & $\begin{array}{l}\text { Ec Bus. } \\
\text { Rel. enl. } \\
\text { (EC) }\end{array}$ & $\begin{array}{l}\text { Addit. } \\
\text { Rem. } \\
\text { (EC) }\end{array}$ & $\begin{array}{l}\text { Cross Dir. } \\
\text { (EC) }\end{array}$ & $\begin{array}{l}\text { Perman. } \\
\text { (EC) }\end{array}$ \\
\hline Alleanza Assicurazioni & 9 & 1 & 29 & 31 & 14 & 9 & 1 & 35 & 31 \\
\hline Assicurazioni Generali & 9 & 1 & 1 & 1 & 26 & 9 & 24 & 1 & 26 \\
\hline Autogrill & 9 & 1 & 1 & 1 & 26 & 9 & 1 & 1 & 37 \\
\hline Autostrade & 9 & 1 & 1 & 32 & 12 & 9 & 1 & 1 & 1 \\
\hline Banca Antonveneta & 9 & 1 & 1 & 35 & 7 & 9 & 32 & 1 & 1 \\
\hline Banca Fideuram & 9 & 1 & 1 & 1 & 26 & 9 & 1 & 1 & 38 \\
\hline Banca Intesa & 9 & 1 & 1 & 34 & 10 & 9 & 27 & 1 & 21 \\
\hline Banca Monte dei Paschi di Siena & 9 & 39 & 1 & 1 & 26 & 9 & 31 & 31 & 23 \\
\hline Banca Popolare di Milano & 9 & 1 & 1 & 1 & 15 & 9 & 30 & 1 & $\overline{19}$ \\
\hline Banche Popolari Unite & 9 & 1 & 1 & 1 & 26 & 9 & 34 & 27 & 38 \\
\hline Banco Popolare di Verona e Novara & 9 & 1 & 1 & 1 & 21 & 9 & 37 & 34 & 33 \\
\hline Benetton & 9 & 1 & 29 & 1 & 26 & 9 & 37 & 1 & 1 \\
\hline $\mathrm{BNL}$ & 9 & 40 & 29 & 1 & 26 & 9 & 1 & 26 & 25 \\
\hline Bulgari & 9 & 1 & 29 & 39 & 1 & 9 & 1 & 1 & 34 \\
\hline Capitalia & 9 & 1 & 29 & 28 & 19 & 9 & 1 & 28 & 17 \\
\hline E.Biscom (Fastweb) & 9 & 1 & 1 & 1 & 26 & 9 & 1 & 1 & 1 \\
\hline Edison & 3 & 1 & 29 & 1 & 26 & 3 & 1 & 1 & 24 \\
\hline Enel & 5 & 1 & 1 & 1 & 3 & 5 & 29 & 1 & 1 \\
\hline ENI & 6 & 1 & 1 & 1 & 6 & 6 & 27 & 1 & 21 \\
\hline Fiat & 2 & 1 & 1 & 1 & 15 & 2 & 1 & 1 & 1 \\
\hline Finmeccanica & 8 & 1 & 1 & 1 & 12 & 8 & 1 & 1 & 1 \\
\hline Fondiaria SAI & 9 & 1 & 1 & 26 & 24 & 9 & 26 & 40 & 27 \\
\hline Gruppo Editoriale l'Espresso & 9 & 1 & 29 & 37 & 3 & 9 & 1 & 28 & 38 \\
\hline Italcementi & 9 & 1 & 1 & 28 & 19 & 9 & 37 & 28 & 34 \\
\hline Luxottica & 9 & 1 & 1 & 1 & 26 & 9 & 1 & 1 & 34 \\
\hline Mediaset & 9 & 1 & 1 & 37 & 3 & 9 & 1 & 1 & 32 \\
\hline Mediobanca & 9 & 1 & 29 & 30 & 15 & 9 & 1 & 32 & 1 \\
\hline Mediolanum & 9 & 1 & 29 & 39 & 1 & 9 & 1 & 1 & 1 \\
\hline Mondatori & 9 & 1 & 1 & 35 & 7 & 9 & 1 & 1 & 1 \\
\hline Pirelli \& Co & 9 & 1 & 1 & 1 & 22 & 9 & 1 & 39 & 29 \\
\hline RAS & 9 & 1 & 1 & 25 & 25 & 9 & 25 & 36 & 28 \\
\hline RCS Mediagroup & 9 & 1 & 29 & 1 & 26 & 9 & 1 & 1 & $\overline{1}$ \\
\hline San Paolo IMI & 9 & 1 & 29 & 32 & 7 & 9 & 35 & 36 & 19 \\
\hline Seat Pagine Gialle & 9 & 1 & 1 & 1 & 26 & 9 & 1 & 1 & $\overline{1}$ \\
\hline Snam Rete Gas & 9 & 1 & 1 & 1 & 26 & 9 & 1 & 1 & 1 \\
\hline STMicroelectronics & 6 & 1 & 29 & 1 & 10 & 6 & 36 & 1 & 29 \\
\hline Telecom Italia & 4 & 1 & 1 & 1 & 15 & 4 & 1 & 32 & 1 \\
\hline Telecom Italia Mobile & 9 & 1 & 1 & 1 & 26 & 9 & 1 & 1 & 1 \\
\hline Tiscali & 1 & 1 & 1 & 1 & 26 & 1 & 37 & 1 & 1 \\
\hline Unicredito & 9 & 1 & 1 & 27 & 23 & 9 & 32 & 38 & 18 \\
\hline
\end{tabular}

The table represents company rankings according to every independence criterion. See Appendix A for more detailed rankings and values. 
Table 10.1 Comparative company scores by EC/Preda compliance rates

\begin{tabular}{|c|c|c|c|c|c|c|c|c|c|}
\hline Company & $\begin{array}{l}\text { Bus.Rel. } \\
\text { (Preda) }\end{array}$ & $\begin{array}{l}\text { Shares } \\
\text { Owned } \\
\text { (Preda) }\end{array}$ & $\begin{array}{l}\text { Family } \\
\text { Ties } \\
\text { (EC\Preda) }\end{array}$ & $\begin{array}{l}\text { Profess. } \\
\text { Qualif. } \\
\text { (EC\Preda) }\end{array}$ & $\begin{array}{l}\text { Other } \\
\text { Comm. } \\
\text { (EC\Preda) }\end{array}$ & $\begin{array}{l}\text { Ec Bus. } \\
\text { Rel. Enl. } \\
\text { (EC) }\end{array}$ & $\begin{array}{l}\text { Addit. } \\
\text { Rem. } \\
\text { (EC) }\end{array}$ & $\begin{array}{l}\text { Cross Dir. } \\
\text { (EC) }\end{array}$ & $\begin{array}{l}\text { Perman. } \\
\text { (EC) }\end{array}$ \\
\hline Alleanza Assicurazioni & 0 & 100 & 0 & 78 & 33 & 0 & 100 & 78 & 56 \\
\hline Assicurazioni Generali & 0 & 100 & 100 & 100 & 0 & 0 & 92 & 100 & 62 \\
\hline Autogrill & 0 & 100 & 100 & 100 & 0 & 0 & 100 & 100 & 25 \\
\hline Autostrade & 0 & 100 & 100 & 75 & 37 & 0 & 100 & 100 & 100 \\
\hline Banca Antonveneta & 0 & 100 & 100 & 67 & 50 & 0 & 67 & 100 & 100 \\
\hline Banca Fideuram & 0 & 100 & 100 & 100 & 0 & 0 & 100 & 100 & 0 \\
\hline Banca Intesa & 0 & 100 & 100 & 71 & 43 & 0 & 86 & 100 & 71 \\
\hline Banca Monte dei Paschi di Siena & 0 & 94 & 100 & 100 & 0 & 0 & 69 & 81 & 69 \\
\hline Banca Popolare di Milano & 0 & 100 & 100 & 100 & 30 & 0 & 80 & 100 & 75 \\
\hline Banche Popolari Unite & 0 & 100 & 100 & 100 & 0 & 0 & 45 & 90 & 0 \\
\hline Banco Popolare di Verona e Novara & 0 & 100 & 100 & 100 & 24 & 0 & 0 & 79 & 37 \\
\hline Benetton & 0 & 100 & 0 & 100 & 0 & 0 & 0 & 100 & 100 \\
\hline $\mathrm{BNL}$ & 0 & 91 & 0 & 100 & 0 & 0 & 100 & 91 & 64 \\
\hline Bulgari & 0 & 100 & 0 & 33 & 100 & 0 & 100 & 100 & 33 \\
\hline Capitalia & 0 & 100 & 0 & 83 & 25 & 0 & 100 & 83 & 83 \\
\hline E.Biscom (Fastweb) & 0 & 100 & 100 & 100 & 0 & 0 & 100 & 100 & 100 \\
\hline Edison & 67 & 100 & 0 & 100 & 0 & 67 & 100 & 100 & 67 \\
\hline Enel & 33 & 100 & 100 & 100 & 75 & 33 & 83 & 100 & 100 \\
\hline ENI & 29 & 100 & 100 & 100 & 64 & 29 & 86 & 100 & 71 \\
\hline Fiat & 80 & 100 & 100 & 100 & 30 & 80 & 100 & 100 & 100 \\
\hline Finmeccanica & 25 & 100 & 100 & 100 & 37 & 25 & 100 & 100 & 100 \\
\hline Fondiaria SAI & 0 & 100 & 100 & 90 & 15 & 0 & 90 & 70 & 60 \\
\hline Gruppo Editoriale l'Espresso & 0 & 100 & 0 & 50 & 75 & 0 & 100 & 83 & 0 \\
\hline Italcementi & 0 & 100 & 100 & 83 & 25 & 0 & 0 & 83 & 33 \\
\hline Luxottica & 0 & 100 & 100 & 100 & 0 & 0 & 100 & 100 & 33 \\
\hline Mediaset & 0 & 100 & 100 & 50 & 75 & 0 & 100 & 100 & 50 \\
\hline Mediobanca & 0 & 100 & 0 & 80 & 30 & 0 & 100 & 80 & 100 \\
\hline Mediolanum & 0 & 100 & 0 & 33 & 100 & 0 & 100 & 100 & 100 \\
\hline Mondadori & 0 & 100 & 100 & 67 & 50 & 0 & 100 & 100 & 100 \\
\hline Pirelli \& Co & 0 & 100 & 100 & 100 & 21 & 0 & 100 & 71 & 57 \\
\hline RAS & 0 & 100 & 100 & 92 & 12 & 0 & 92 & 75 & 58 \\
\hline RCS Mediagroup & 0 & 100 & 0 & 100 & 0 & 0 & 100 & 100 & 100 \\
\hline San Paolo IMI & 0 & 100 & 0 & 75 & 50 & 0 & 25 & 75 & 75 \\
\hline Seat Pagine Gialle & 0 & 100 & 100 & 100 & 0 & 0 & 100 & 100 & 100 \\
\hline Snam Rete Gas & 0 & 100 & 100 & 100 & 0 & 0 & 100 & 100 & 100 \\
\hline STMicroelectronics & 29 & 100 & 0 & 100 & 43 & 29 & 14 & 100 & 57 \\
\hline Telecom Italia & 40 & 100 & 100 & 100 & 30 & 40 & 100 & 80 & 100 \\
\hline Telecom Italia Mobile & 0 & 100 & 100 & 100 & 0 & 0 & 100 & 100 & 100 \\
\hline Tiscali & 100 & 100 & 100 & 100 & 0 & 100 & 0 & 100 & 100 \\
\hline Unicredito & 0 & 100 & 100 & 87 & 20 & 0 & 67 & 73 & 80 \\
\hline
\end{tabular}

Scores are computed according to equation (7). 


\section{Table 11. Cross-directorship networks in 2003}

The table reports the companies on whose boards independent directors who took part in crossdirectorsip schemes sat in 2003. Numbers in the small boxes refer to the EC global compliance rate and the number in brackets refer to the incidence of directors involved in cross-directorships schemes on the total number of independent directors. The colour is referred to four classes of quality: in yellow companies with a compliance rate above 0.70; in light grey companies with a compliance rate between 0.60 and 0.70 ; in dark grey companies between 0.50 and 0.60 ; in the darkest shade of grey companies between 0.40 and 0.50. In white companies that do not belong to our population of S\&P-MIB 40. Thin arrows refer to cross-directorship links; arrows in bold refer to ownership links (above $2 \%$ of total voting shares); dotted arrows in bold refer to ownership links (above $2 \%$ of total voting shares) involving a controlling shareholder of the company.

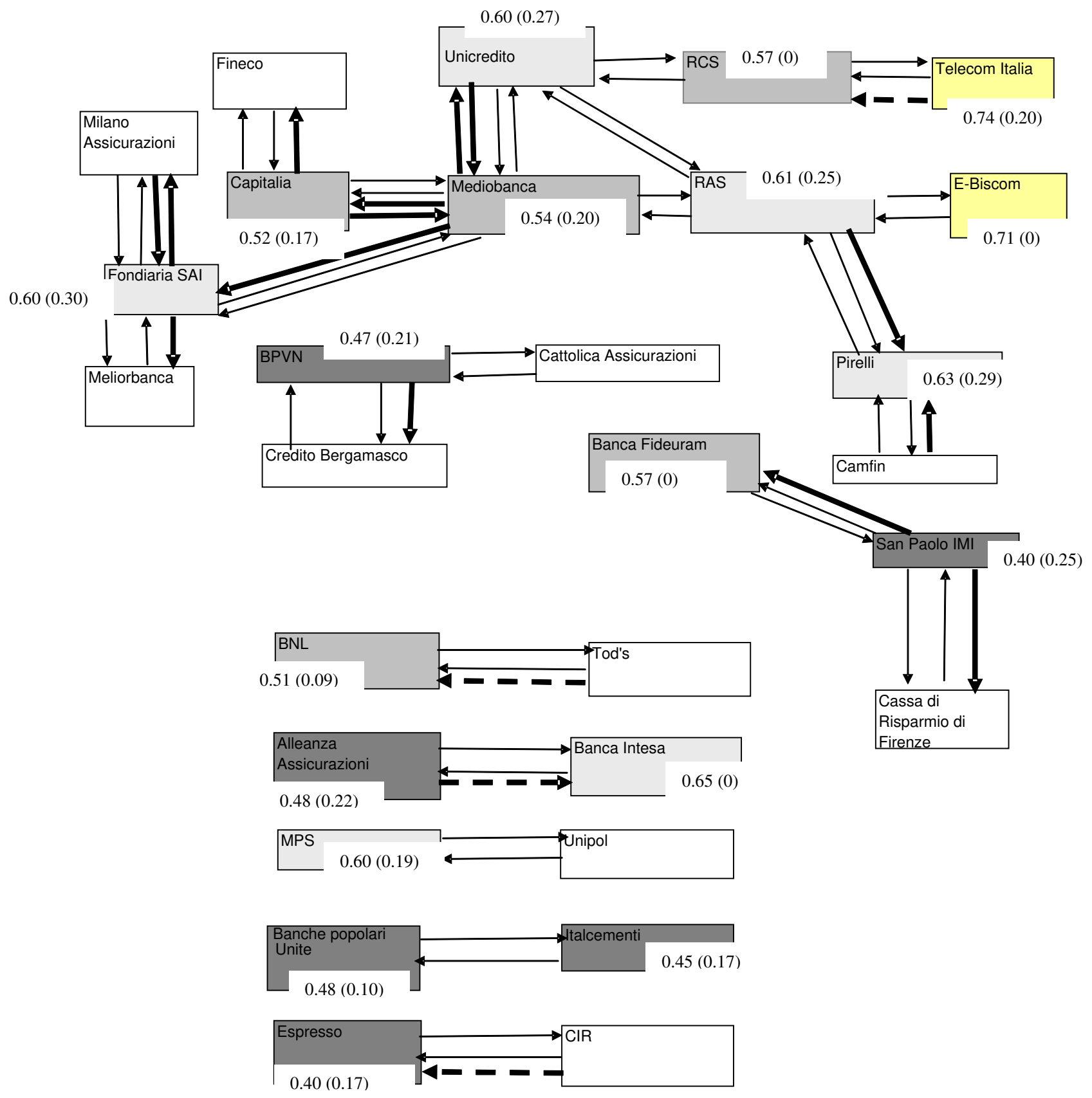




\section{Table 12. Dual-directorship networks in 2003}

The table reports the companies on whose boards independent directors who take part in dualdirectorsip schemes sat in 2003. Numbers in the small boxes refer to the number of dualdirectorships, while numbers in brackets refer to the incidence of directors involved in dualdirectorships schemes on the total number of independent directors.

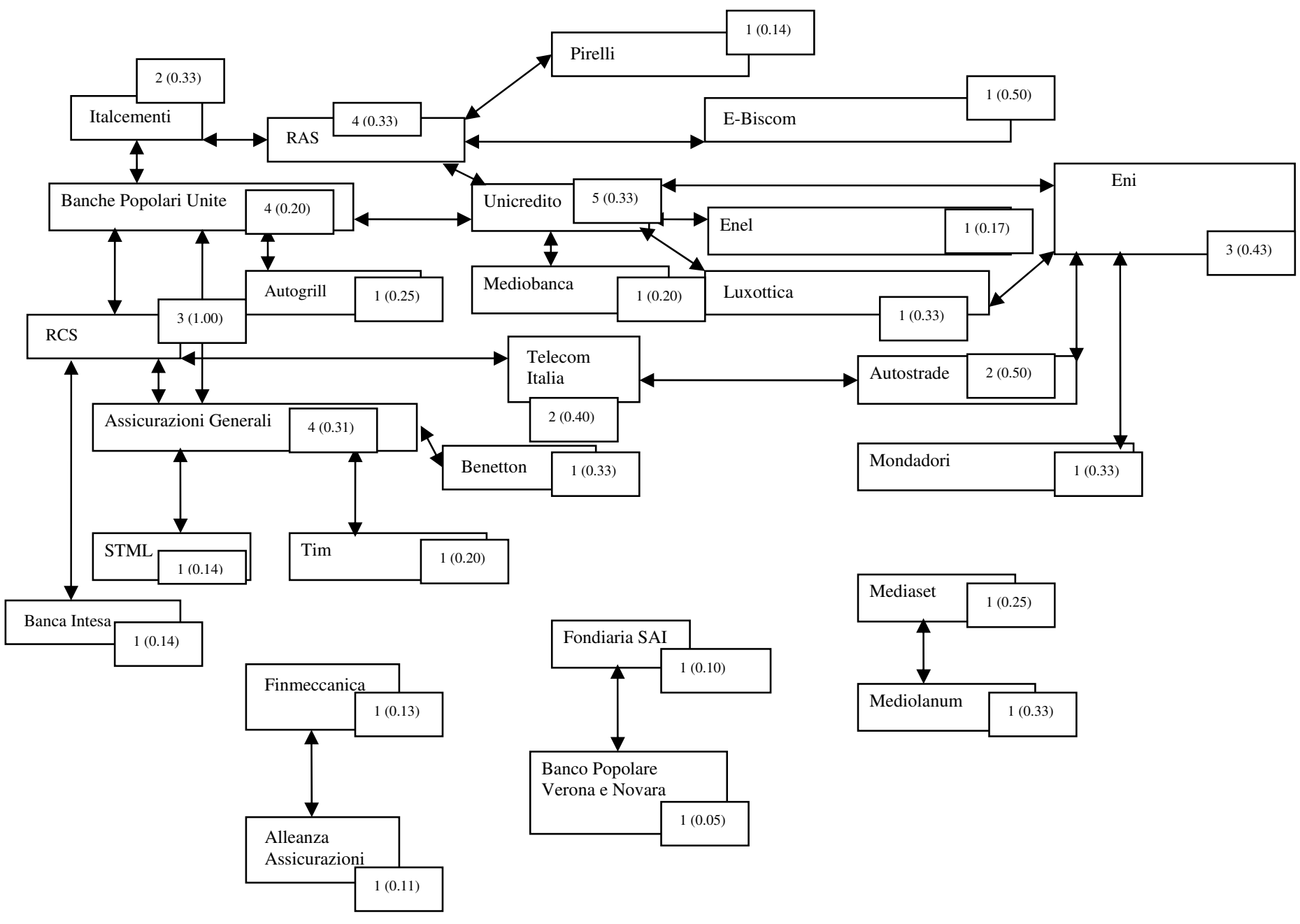


Table 13. Dual and Cross-Directorship networks
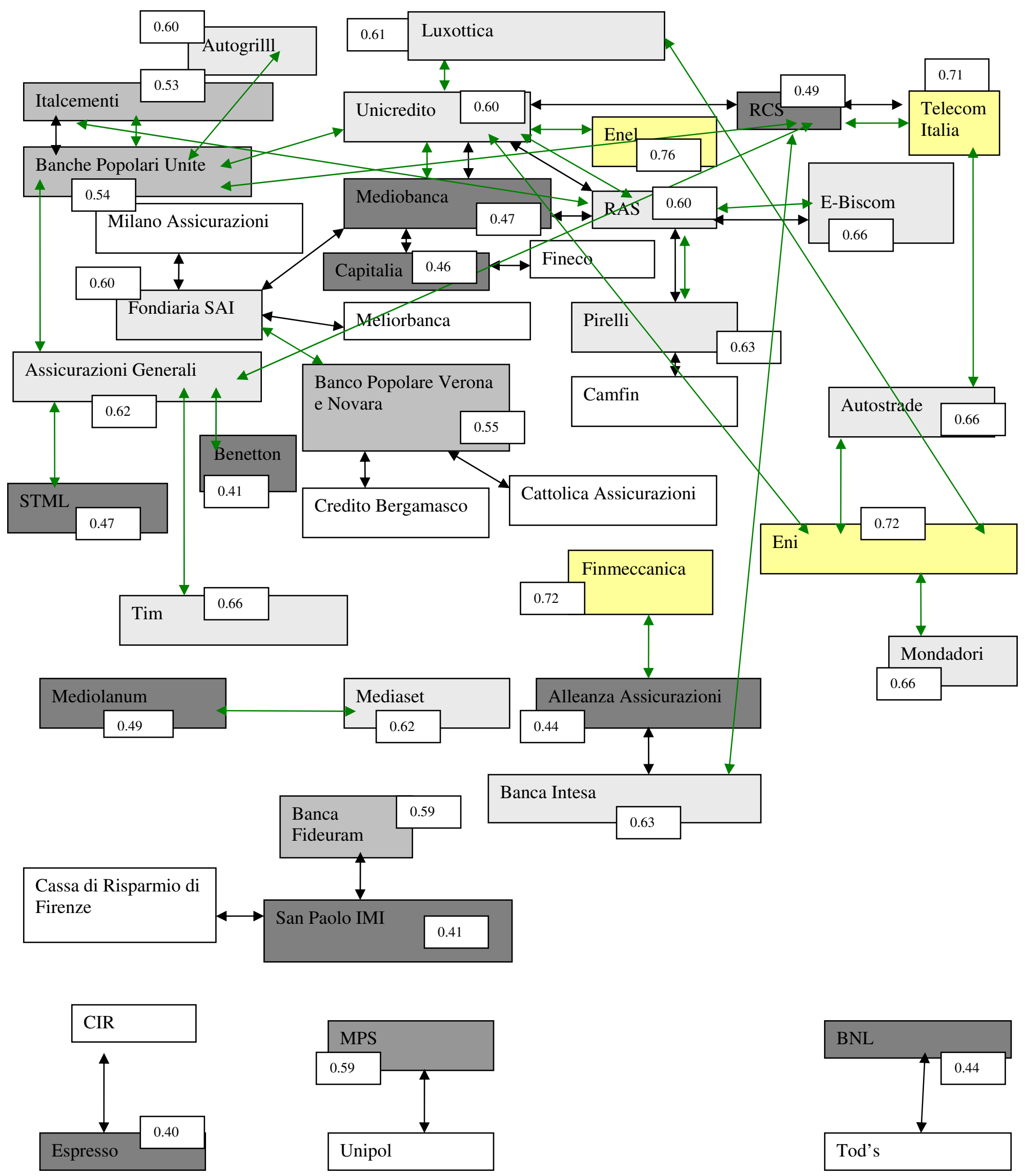
Numbers in boxes indicate average Preda-EC compliance. The Table represents at the same time the networks illustrated in Table 11 and in Table 12, following the same colour classification used in Table 11.

Table 14. Incidence of dual and cross-directorships.

\begin{tabular}{|c|c|c|c|c|c|c|c|c|}
\hline Company & \begin{tabular}{|c|} 
Ind. \\
Directors
\end{tabular} & $\begin{array}{c}\text { Dual } \\
\text { Dir. (1) }\end{array}$ & $\begin{array}{c}\text { Multiple } \\
\text { Dir. (2) }\end{array}$ & $\begin{array}{l}\text { Cross } \\
\text { Dir.(3) }\end{array}$ & $\begin{array}{c}\text { Cross } \\
\text { and dual } \\
\text { dir.(4) }\end{array}$ & $\begin{array}{c}\text { incidence } \\
\text { d.d (1) }\end{array}$ & $\begin{array}{c}\text { incidence } \\
\text { c.d (3) }\end{array}$ & $\begin{array}{c}\text { incidence } \\
\text { cd.d (4) }\end{array}$ \\
\hline Alleanza Assicurazioni & 9 & 1 & 0 & 2 & 0 & 0.11 & 0.22 & 0 \\
\hline Assicurazioni Generali & 13 & 4 & 1 & 0 & 0 & 0.31 & 0 & 0 \\
\hline Autogrill & 4 & 1 & 0 & 0 & 0 & 0.25 & 0 & 0 \\
\hline Autostrade & 4 & 2 & 0 & 0 & 0 & 0.5 & 0 & 0 \\
\hline$\overline{B N L}$ & 11 & 0 & 0 & 1 & 0 & 0 & 0.09 & 0 \\
\hline Banca Antonveneta & 3 & 0 & 0 & 0 & 0 & 0 & 0 & 0 \\
\hline Banca Fideuram & 2 & 0 & 0 & 0 & 0 & 0 & 0 & 0 \\
\hline Banca Intesa & 7 & 1 & 0 & 0 & 0 & 0.14 & 0 & 0 \\
\hline Banca Monte dei Paschi & 16 & 0 & 0 & 3 & 0 & 0 & 0.19 & 0 \\
\hline Banca Popolare di Milano & 20 & 0 & 0 & 0 & 0 & 0 & 0 & 0 \\
\hline Banche Popolari Unite & 20 & 4 & 1 & 2 & 1 & 0.2 & 0.1 & 0.05 \\
\hline Banco Popolare di V.e N. & 19 & 1 & 0 & 4 & 0 & 0.05 & 0.21 & 0 \\
\hline Benetton & 3 & 1 & 0 & 0 & 0 & 0.33 & 0 & 0 \\
\hline Bulgari & 3 & 0 & 0 & 0 & 0 & 0 & 0 & 0 \\
\hline Capitalia & 6 & 0 & 0 & 1 & 0 & 0 & 0.17 & 0 \\
\hline E.Biscom (Fastweb) & 2 & 1 & 0 & 0 & 0 & 0.5 & 0 & 0 \\
\hline$\overline{\mathrm{ENI}}$ & 7 & 3 & 1 & 0 & 0 & 0.43 & 0 & 0 \\
\hline Edison & 3 & 0 & 0 & 0 & 0 & 0 & 0 & 0 \\
\hline Enel & 6 & 1 & 0 & 0 & 0 & 0.17 & 0 & 0 \\
\hline Fiat & 5 & 0 & 0 & 0 & 0 & 0 & 0 & 0 \\
\hline Finmeccanica & 8 & 1 & 0 & 0 & 0 & 0.13 & 0 & 0 \\
\hline Fondiaria SAI & 10 & 1 & 0 & 3 & 0 & 0.1 & 0.3 & 0 \\
\hline $\begin{array}{l}\text { Gruppo Editoriale } \\
\text { l'Espresso }\end{array}$ & 6 & 0 & 0 & 1 & 0 & 0 & 0.17 & 0 \\
\hline Italcementi & 6 & 2 & 0 & 1 & 1 & 0.33 & 0.17 & 0.17 \\
\hline Luxottica & 3 & 1 & 1 & 0 & 0 & 0.33 & 0 & 0 \\
\hline Mediaset & 4 & 1 & 0 & 0 & 0 & 0.25 & 0 & 0 \\
\hline Mediobanca & 5 & 1 & 0 & 1 & 0 & 0.2 & 0.2 & 0 \\
\hline Mediolanum & 3 & 1 & 0 & 0 & 0 & 0.33 & 0 & 0 \\
\hline Mondadori & 3 & 1 & 0 & 0 & 0 & 0.33 & 0 & 0 \\
\hline Pirelli \& Co & 7 & 1 & 0 & 2 & 1 & 0.14 & 0.29 & $\overline{0.14}$ \\
\hline RAS & 12 & 4 & 0 & 3 & 2 & 0.33 & 0.25 & 0.17 \\
\hline RCS Mediagroup & 3 & 3 & 1 & 0 & 0 & 1 & 0 & 0 \\
\hline STMicroelectronics & 7 & 1 & 0 & 0 & 0 & 0.14 & 0 & 0 \\
\hline San Paolo IMI & 12 & 0 & 0 & 3 & 0 & 0 & 0.25 & 0 \\
\hline Seat Pagine Gialle & 3 & 0 & 0 & 0 & 0 & 0 & 0 & 0 \\
\hline Snam Rete Gas & 2 & 0 & 0 & 0 & 0 & 0 & 0 & 0 \\
\hline Telecom Italia & 5 & 2 & 0 & 1 & 1 & 0.4 & 0.2 & 0.2 \\
\hline Telecom Italia Mobile & 5 & 1 & 0 & 0 & 0 & 0.2 & 0 & 0 \\
\hline Tiscali & 2 & 0 & 0 & 0 & 0 & 0 & 0 & 0 \\
\hline Unicredito & 15 & 5 & 1 & 4 & 3 & 0.33 & 0.27 & 0.2 \\
\hline 50th perc.S \& P MIB & 5.5 & 1 & 0 & 0 & 0 & 0.14 & 0 & 0 \\
\hline Sum S \& P MIB & 284 & 46 & 6 & 33 & 9 & 0.16 & 0.12 & 0.03 \\
\hline
\end{tabular}


For each company we represent, from left to right, respectively the total number of independent directors, the number of dual-directorships, the number of multiple directorships (independent directors sitting on more than two company boards at the same time as independent), the number of cross-directorships, the number of directors who are at the same time part of a scheme of crossdirectorships and dual-directorships. The last three columns measure the incidence respectively of: dual-directorships on the total number of each company independent directors, cross-directorships on the total number of each company independent directors, and cross and dual-directorships on the total number of each company independent directors.

\section{Table 15. Rankings by set of criteria (EC and Preda)}

The tables report the global criteria and the relative performance with respect to the maximum performance of all the 40 S\&P-MIB companies of the population. Ranks are assigned according to the compliance level with independence requirements. Group 1 includes the first ten ranks (taking into account that the third rank is held by three companies with the same compliance level and that the $7^{\text {th }}$ rank is held by 6 companies with the same compliance level); Group 2 includes the following ten ranks, and so on. The position of each company in the rank identifies its group (1,2,3 or 4). Results of the original rates are multiplied by 100 . 
EC compliance (yes)

\begin{tabular}{|c|c|c|c|c|}
\hline Rank & Company & Global rate ec_yes & $\max S \& P$ mib $=100$ & Group \\
\hline 1 & Fiat & 80 & 100 & $\overline{1}$ \\
\hline 2 & Enel & 78.57 & 98 & 1 \\
\hline 3 & Finmeccanica & 76.79 & 96 & 1 \\
\hline 4 & Telecom Italia & 74.29 & 93 & $\overline{1}$ \\
\hline 5 & ENI & 73.47 & 92 & 1 \\
\hline 6 & Autostrade & 71.43 & 89 & 1 \\
\hline 6 & E.Biscom (Fastweb) & 71.43 & 89 & 1 \\
\hline 6 & Mondadori & 71.43 & 89 & 1 \\
\hline 6 & Seat Pagine Gialle & 71.43 & 89 & 1 \\
\hline 6 & Snam Rete Gas & 71.43 & 89 & $\overline{1}$ \\
\hline 6 & Telecom Italia Mobile & 71.43 & 89 & 1 \\
\hline 12 & Banca Popolare di Milano & 67.86 & 85 & 2 \\
\hline 13 & Banca Antonveneta & 66.67 & 83 & 2 \\
\hline 14 & Banca Intesa & 65.31 & 82 & 2 \\
\hline 15 & Assicurazioni Generali & 64.84 & 81 & 2 \\
\hline 16 & Mediaset & 64.29 & 80 & 2 \\
\hline 16 & Tiscali & 64.29 & 80 & 2 \\
\hline 18 & Pirelli \& Co & 63.27 & 79 & 2 \\
\hline 19 & Luxottica & 61.9 & 77 & 2 \\
\hline 20 & RAS & 60.71 & 76 & 2 \\
\hline 21 & Autogrill & 60.71 & 76 & 3 \\
\hline 22 & Fondiaria SAI & 60 & 75 & 3 \\
\hline 22 & Unicredito & 60 & 75 & 3 \\
\hline 24 & Banca Monte dei Paschi di Siena & 59.82 & 75 & 3 \\
\hline 25 & Banca Fideuram & 57.14 & 71 & 3 \\
\hline 25 & Edison & 57.14 & 71 & 3 \\
\hline 25 & Mediolanum & 57.14 & 71 & 3 \\
\hline 25 & RCS Mediagroup & 57.14 & 71 & 3 \\
\hline 29 & Mediobanca & 54.29 & 68 & 3 \\
\hline 30 & Capitalia & 52.38 & 65 & 3 \\
\hline 31 & $\mathrm{BNL}$ & 50.65 & 63 & 4 \\
\hline 32 & Banche Popolari Unite & 47.86 & 60 & $\overline{4}$ \\
\hline 33 & Alleanza Assicurazioni & 47.62 & 60 & $\overline{4}$ \\
\hline 33 & Bulgari & 47.62 & 60 & 4 \\
\hline 35 & Banco Popolare di Verona e Novara & 47.37 & 59 & 4 \\
\hline 36 & Italcementi & 45.24 & 57 & 4 \\
\hline 37 & STMicroelectronics & 44.9 & 56 & 4 \\
\hline 38 & Benetton & 42.86 & 54 & 4 \\
\hline 39 & Gruppo Editoriale l'Espresso & 40.48 & 51 & $\overline{4}$ \\
\hline 39 & San Paolo IMI & 40.48 & 51 & 4 \\
\hline
\end{tabular}


EC not compliance (no)

\begin{tabular}{|c|c|c|c|c|}
\hline Rank & Company & Global rate ec_no & $\max S \& P$ mib $=100$ & Group \\
\hline 1 & Bulgari & 0 & 0 & 1 \\
\hline 2 & Gruppo Editoriale I'Espresso & 4.76 & 15 & 1 \\
\hline 2 & Mediolanum & 4.76 & 15 & 1 \\
\hline 4 & Autostrade & 7.14 & 22 & 1 \\
\hline 4 & Mediaset & 7.14 & 22 & 1 \\
\hline 6 & Benetton & 9.52 & 29 & 1 \\
\hline 6 & Capitalia & 9.52 & 29 & 1 \\
\hline 6 & Mondadori & 9.52 & 29 & 1 \\
\hline 9 & Alleanza Assicurazioni & 11.11 & 34 & 1 \\
\hline 10 & Autogrill & 14.29 & 44 & 1 \\
\hline 10 & Banca Antonveneta & 14.29 & 44 & 1 \\
\hline 10 & Banca Fideuram & 14.29 & 44 & 1 \\
\hline 10 & E.Biscom (Fastweb) & 14.29 & 44 & 1 \\
\hline 10 & Edison & 14.29 & 44 & 1 \\
\hline 10 & Enel & 14.29 & 44 & 1 \\
\hline 10 & ENI & 14.29 & 44 & $\overline{1}$ \\
\hline 10 & RCS Mediagroup & 14.29 & 44 & 1 \\
\hline 10 & Seat Pagine Gialle & 14.29 & 44 & 1 \\
\hline 10 & Snam Rete Gas & 14.29 & 44 & 1 \\
\hline 10 & Telecom Italia & 14.29 & 44 & 1 \\
\hline 10 & Telecom Italia Mobile & 14.29 & 44 & 1 \\
\hline 22 & Fondiaria SAI & 15.71 & 48 & 3 \\
\hline 23 & Banca Intesa & 16.33 & 50 & 3 \\
\hline 24 & Assicurazioni Generali & 16.48 & 50 & 3 \\
\hline 25 & BNL & 16.88 & 52 & 3 \\
\hline 26 & Finmeccanica & 17.86 & 55 & 3 \\
\hline 27 & Fiat & 20 & 61 & 3 \\
\hline 27 & Mediobanca & 20 & 61 & 3 \\
\hline 29 & Banca Popolare di Milano & 21.43 & 66 & 3 \\
\hline 29 & Italcementi & 21.43 & 66 & 3 \\
\hline 29 & Tiscali & 21.43 & 66 & 3 \\
\hline 32 & Unicredito & 21.91 & 67 & 4 \\
\hline 33 & Pirelli \& Co & 22.45 & 69 & 4 \\
\hline 34 & Banco Popolare di Verona e Novara & 24.06 & 74 & 4 \\
\hline 35 & RAS & 25 & 77 & 4 \\
\hline 36 & San Paolo IMI & 27.38 & 84 & 4 \\
\hline 37 & Banca Monte dei Paschi di Siena & 28.57 & 88 & 4 \\
\hline 37 & Luxottica & 28.57 & 88 & 4 \\
\hline 39 & Banche Popolari Unite & 30 & 92 & 4 \\
\hline 40 & STMicroelectronics & 32.65 & 100 & 4 \\
\hline
\end{tabular}


EC not disclosure (ns)

\begin{tabular}{|c|c|c|c|c|}
\hline Rank & Company & Global rate ec ns & $\max$ S\&P mib=100 & Group \\
\hline 1 & Fiat & 0 & 0 & 1 \\
\hline 2 & Finmeccanica & 5.36 & 10 & 1 \\
\hline 3 & Enel & 7.14 & 13 & 1 \\
\hline 4 & Luxottica & 9.52 & 17 & 1 \\
\hline 5 & Banca Popolare di Milano & 10.71 & 20 & 1 \\
\hline 6 & Telecom Italia & 11.43 & 21 & 1 \\
\hline 7 & Banca Monte dei Paschi di Siena & 11.61 & 21 & 1 \\
\hline 8 & ENI & 12.25 & 22 & 1 \\
\hline 9 & E.Biscom (Fastweb) & 14.29 & 26 & 1 \\
\hline 9 & Pirelli \& Co & 14.29 & 26 & 1 \\
\hline 9 & RAS & 14.29 & 26 & 1 \\
\hline 9 & Seat Pagine Gialle & 14.29 & 26 & 1 \\
\hline 9 & Snam Rete Gas & 14.29 & 26 & 1 \\
\hline 9 & Telecom Italia Mobile & 14.29 & 26 & 1 \\
\hline 9 & Tiscali & 14.29 & 26 & 1 \\
\hline 16 & Unicredito & 18.1 & 33 & 2 \\
\hline 17 & Banca Intesa & 18.37 & 34 & 2 \\
\hline 18 & Assicurazioni Generali & 18.68 & 34 & 2 \\
\hline 19 & Banca Antonveneta & 19.05 & 35 & 2 \\
\hline 19 & Mondadori & 19.05 & 35 & 2 \\
\hline 21 & Autostrade & 21.43 & 39 & 3 \\
\hline 22 & Banche Popolari Unite & 22.14 & 40 & 3 \\
\hline 23 & STMicroelectronics & 22.45 & 41 & 3 \\
\hline 24 & Fondiaria SAI & 24.29 & 44 & 3 \\
\hline 25 & Autogrill & 25 & 46 & 3 \\
\hline 26 & Mediobanca & 25.71 & 47 & 3 \\
\hline 27 & Banca Fideuram & 28.57 & 52 & 3 \\
\hline 27 & Banco Popolare di Verona e Novara & 28.57 & 52 & 3 \\
\hline 27 & Edison & 28.57 & 52 & 3 \\
\hline 27 & Mediaset & 28.57 & 52 & 3 \\
\hline 27 & RCS Mediagroup & 28.57 & 52 & 3 \\
\hline 32 & San Paolo IMI & 32.14 & 59 & 4 \\
\hline 33 & BNL & 32.47 & 59 & 4 \\
\hline 34 & Italcementi & 33.33 & 61 & 4 \\
\hline 35 & Capitalia & 38.1 & 70 & 4 \\
\hline 35 & Mediolanum & 38.1 & 70 & 4 \\
\hline 37 & Alleanza Assicurazioni & 41.27 & 75 & 4 \\
\hline 38 & Benetton & 47.62 & 87 & 4 \\
\hline 39 & Bulgari & 52.38 & 96 & 4 \\
\hline 40 & Gruppo Editoriale I'Espresso & 54.76 & 100 & 4 \\
\hline
\end{tabular}


Preda compliance (yes)

\begin{tabular}{|c|c|c|c|c|}
\hline Rank & Company & Global rate pr_yes & $\max \mathrm{S} \& \mathrm{P}$ mib $=100$ & Group \\
\hline 1 & Enel & 73.33 & 100 & $\overline{1}$ \\
\hline 2 & Fiat & 72 & 98 & 1 \\
\hline 3 & ENI & 71.43 & 97 & 1 \\
\hline 4 & Tiscali & 70 & 95 & 1 \\
\hline 5 & Telecom Italia & 68 & 93 & 1 \\
\hline 6 & Finmeccanica & 67.5 & 92 & 1 \\
\hline 7 & Banca Popolare di Milano & 64 & 87 & $\overline{1}$ \\
\hline 8 & Banco Popolare di Verona e Novara & 63.16 & 86 & 1 \\
\hline 9 & Pirelli \& Co & 62.86 & 86 & 1 \\
\hline 10 & Assicurazioni Generali & 60 & 82 & 1 \\
\hline 10 & Autogrill & 60 & 82 & 1 \\
\hline 10 & Autostrade & 60 & 82 & 1 \\
\hline 10 & Banca Antonveneta & 60 & 82 & $\overline{1}$ \\
\hline 10 & Banca Fideuram & 60 & 82 & 1 \\
\hline 10 & Banca Intesa & 60 & 82 & 1 \\
\hline 10 & Banche Popolari Unite & 60 & 82 & 1 \\
\hline 10 & E.Biscom (Fastweb) & 60 & 82 & 1 \\
\hline 10 & Fondiaria SAI & 60 & 82 & $\overline{1}$ \\
\hline 10 & Italcementi & 60 & 82 & 1 \\
\hline 10 & Luxottica & 60 & 82 & 1 \\
\hline 10 & Mediaset & 60 & 82 & 1 \\
\hline 10 & Mondadori & 60 & 82 & 1 \\
\hline 10 & RAS & 60 & 82 & 1 \\
\hline 10 & Seat Pagine Gialle & 60 & 82 & $\overline{1}$ \\
\hline 10 & Snam Rete Gas & 60 & 82 & 1 \\
\hline 10 & Telecom Italia Mobile & 60 & 82 & 1 \\
\hline 10 & Unicredito & 60 & 82 & 1 \\
\hline 28 & Banca Monte dei Paschi di Siena & 58.75 & 80 & 3 \\
\hline 29 & STMicroelectronics & 48.57 & 66 & 3 \\
\hline 30 & Edison & 46.67 & 64 & 3 \\
\hline 31 & San Paolo IMI & 41.67 & 57 & 4 \\
\hline 32 & Alleanza Assicurazioni & 40 & 55 & $\overline{4}$ \\
\hline 32 & Benetton & 40 & 55 & 4 \\
\hline 32 & Bulgari & 40 & 55 & 4 \\
\hline 32 & Capitalia & 40 & 55 & 4 \\
\hline 32 & Gruppo Editoriale l'Espresso & 40 & 55 & 4 \\
\hline 32 & Mediobanca & 40 & 55 & 4 \\
\hline 32 & Mediolanum & 40 & 55 & 4 \\
\hline 32 & RCS Mediagroup & 40 & 55 & 4 \\
\hline 40 & $\mathrm{BNL}$ & 38.18 & 52 & 4 \\
\hline
\end{tabular}


Preda not compliance (no)

\begin{tabular}{|c|c|c|c|c|}
\hline Rank & Company & Global rate pr_no & $\max$ S\&P mib $=100$ & Group \\
\hline 1 & Bulgari & 0 & 0 & 1 \\
\hline 2 & Capitalia & 3.33 & 11 & 1 \\
\hline 2 & Gruppo Editoriale l'Espresso & 3.33 & 11 & 1 \\
\hline 4 & Italcementi & 6.67 & 22 & 1 \\
\hline 4 & Mediolanum & 6.67 & 22 & 1 \\
\hline 6 & Alleanza Assicurazioni & 8.89 & 30 & 1 \\
\hline 7 & Autostrade & 10 & 33 & 1 \\
\hline 7 & Banca Fideuram & 10 & 33 & 1 \\
\hline 7 & Mediaset & 10 & 33 & 1 \\
\hline 10 & Banco Popolare di Verona e Novara & 10.53 & 35 & 1 \\
\hline 11 & Banca Antonveneta & 13.33 & 44 & 2 \\
\hline 11 & Benetton & 13.33 & 44 & 2 \\
\hline 11 & Mondadori & 13.33 & 44 & 2 \\
\hline 11 & San Paolo IMI & 13.33 & 44 & 2 \\
\hline 15 & Fondiaria SAI & 14 & 47 & 2 \\
\hline 16 & Banca Intesa & 14.29 & 48 & 2 \\
\hline 16 & ENI & 14.29 & 48 & 2 \\
\hline 18 & Telecom Italia & 16 & 53 & 2 \\
\hline 19 & Enel & 16.67 & 56 & 2 \\
\hline 20 & Banca Popolare di Milano & 17 & 57 & 2 \\
\hline 21 & Pirelli \& Co & 17.14 & 57 & 3 \\
\hline 22 & Unicredito & 17.33 & 58 & 3 \\
\hline 23 & RAS & 18.33 & 61 & 3 \\
\hline 24 & Assicurazioni Generali & 18.46 & 62 & 3 \\
\hline 25 & Autogrill & 20 & 67 & 3 \\
\hline 25 & E.Biscom (Fastweb) & 20 & 67 & 3 \\
\hline 25 & Edison & 20 & 67 & 3 \\
\hline 25 & Luxottica & 20 & 67 & 3 \\
\hline 25 & Mediobanca & 20 & 67 & 3 \\
\hline 25 & RCS Mediagroup & 20 & 67 & 3 \\
\hline 25 & Seat Pagine Gialle & 20 & 67 & 3 \\
\hline 25 & Snam Rete Gas & 20 & 67 & 3 \\
\hline 25 & STMicroelectronics & 20 & 67 & 3 \\
\hline 25 & Telecom Italia Mobile & 20 & 67 & 3 \\
\hline 35 & Banche Popolari Unite & 21 & 70 & 4 \\
\hline 36 & Banca Monte dei Paschi di Siena & 21.25 & 71 & 4 \\
\hline 37 & BNL & 21.82 & 73 & 4 \\
\hline 38 & Finmeccanica & 25 & 83 & 4 \\
\hline 39 & Fiat & 28 & 93 & 4 \\
\hline 40 & Tiscali & 30 & 100 & 4 \\
\hline
\end{tabular}


Preda not disclosure (ns)

\begin{tabular}{|c|c|c|c|c|}
\hline Rank & Company & Global rate pr ns & $\max$ S\&P mib=100 & Group \\
\hline 1 & Fiat & 0 & 0 & $\overline{1}$ \\
\hline 1 & Tiscali & 0 & 0 & 1 \\
\hline 3 & Finmeccanica & 7.5 & 13 & 1 \\
\hline 4 & Enel & 10 & 17 & 1 \\
\hline 5 & ENI & 14.29 & 24 & 1 \\
\hline 6 & Telecom Italia & 16 & 27 & 1 \\
\hline 7 & Banca Popolare di Milano & 19 & 32 & 1 \\
\hline 7 & Banche Popolari Unite & 19 & 32 & 1 \\
\hline 9 & Autogrill & 20 & 33 & 1 \\
\hline 9 & Banca Monte dei Paschi di Siena & 20 & 33 & 1 \\
\hline 9 & E.Biscom (Fastweb) & 20 & 33 & 1 \\
\hline 9 & Luxottica & 20 & 33 & 1 \\
\hline 9 & Pirelli \& Co & 20 & 33 & 1 \\
\hline 9 & Seat Pagine Gialle & 20 & 33 & 1 \\
\hline 9 & Snam Rete Gas & 20 & 33 & 1 \\
\hline 9 & Telecom Italia Mobile & 20 & 33 & 1 \\
\hline 17 & Assicurazioni Generali & 21.54 & 36 & 2 \\
\hline 18 & RAS & 21.67 & 36 & 2 \\
\hline 19 & Unicredito & 22.67 & 38 & 2 \\
\hline 20 & Banca Intesa & 25.71 & 43 & 2 \\
\hline 21 & Fondiaria SAI & 26 & 43 & 3 \\
\hline 22 & Banco Popolare di Verona e Novara & 26.32 & 44 & 3 \\
\hline 23 & Banca Antonveneta & 26.67 & 44 & 3 \\
\hline 23 & Mondadori & 26.67 & 44 & 3 \\
\hline 25 & Autostrade & 30 & 50 & 3 \\
\hline 25 & Banca Fideuram & 30 & 50 & 3 \\
\hline 25 & Mediaset & 30 & 50 & 3 \\
\hline 28 & STMicroelectronics & 31.43 & 52 & 3 \\
\hline 29 & Edison & 33.33 & 56 & 3 \\
\hline 29 & Italcementi & 33.33 & 56 & $\overline{3}$ \\
\hline 31 & BNL & 40 & 67 & 4 \\
\hline 31 & Mediobanca & 40 & 67 & $\overline{4}$ \\
\hline 31 & RCS Mediagroup & 40 & 67 & $\overline{4}$ \\
\hline 34 & San Paolo IMI & 45 & 75 & 4 \\
\hline 35 & Benetton & 46.67 & 78 & 4 \\
\hline 36 & \begin{tabular}{|l} 
Alleanza Assicurazioni \\
\end{tabular} & 51.11 & 85 & 4 \\
\hline 37 & Mediolanum & 53.33 & 89 & 4 \\
\hline 38 & Capitalia & 56.67 & 94 & 4 \\
\hline 38 & Gruppo Editoriale l'Espresso & 56.67 & 94 & $\overline{4}$ \\
\hline 40 & Bulgari & 60 & 100 & $\overline{4}$ \\
\hline
\end{tabular}




\section{Table 16. Comparative Scatter diagrams by free float/capital voting and compliance rates}

Each dot represents one company, all 40 companies are considered except the three Banche popolari due to different shareholder voting rules (one-shareholder-one-vote). See Table 1A for the labels. As a visual aid, each table also depicts a regression line estimated by ordinary least squares. The orthogonal red lines identify the $50^{\text {th }}$ percentile with reference to the entire population minus the three banche popolari. Dots labelled by "0" identify companies that are not part of crossdirectorships schemes. To improve the data visualization some of the scale values are omitted. Cvot is the free float in 2003, source: Consob.
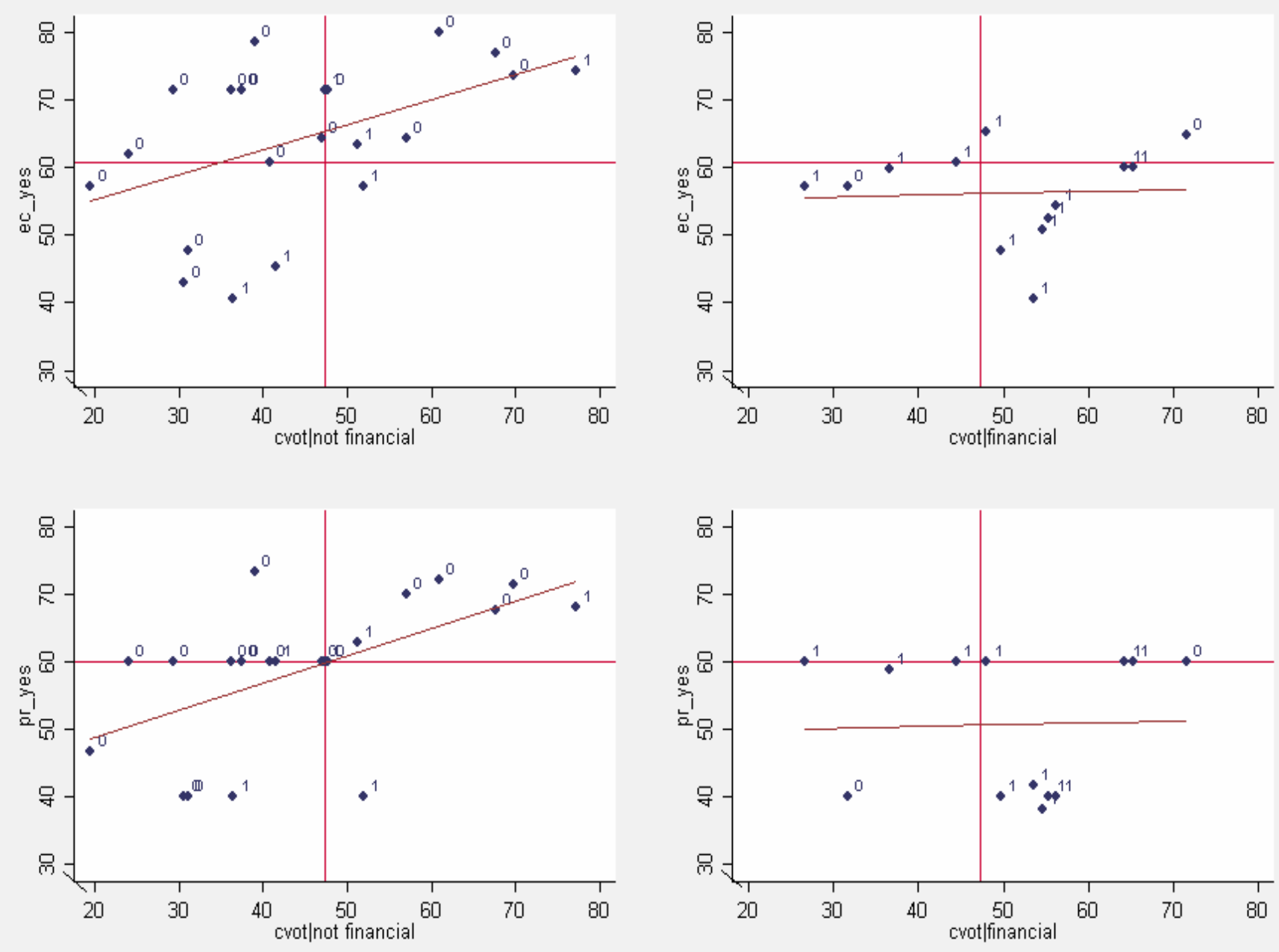


\section{Table 17. Comparative Scatter diagrams on free float/capital voting on not disclosure rates}

Each dot represents one company, all 40 companies are considered except the three Banche popolari due to different shareholder voting rules (one-shareholder-one-vote). See Table 1A for the labels. As a visual aid, each table also depicts a regression line estimated by ordinary least squares. The orthogonal red lines identify the $50^{\text {th }}$ percentile with reference to the entire population minus the three Banche popolari. Dots labelled by "0" identify companies that are not part of crossdirectorships schemes. To improve the data visualization some of the scale values are omitted. Cvot is the free float in 2003, source: Consob.
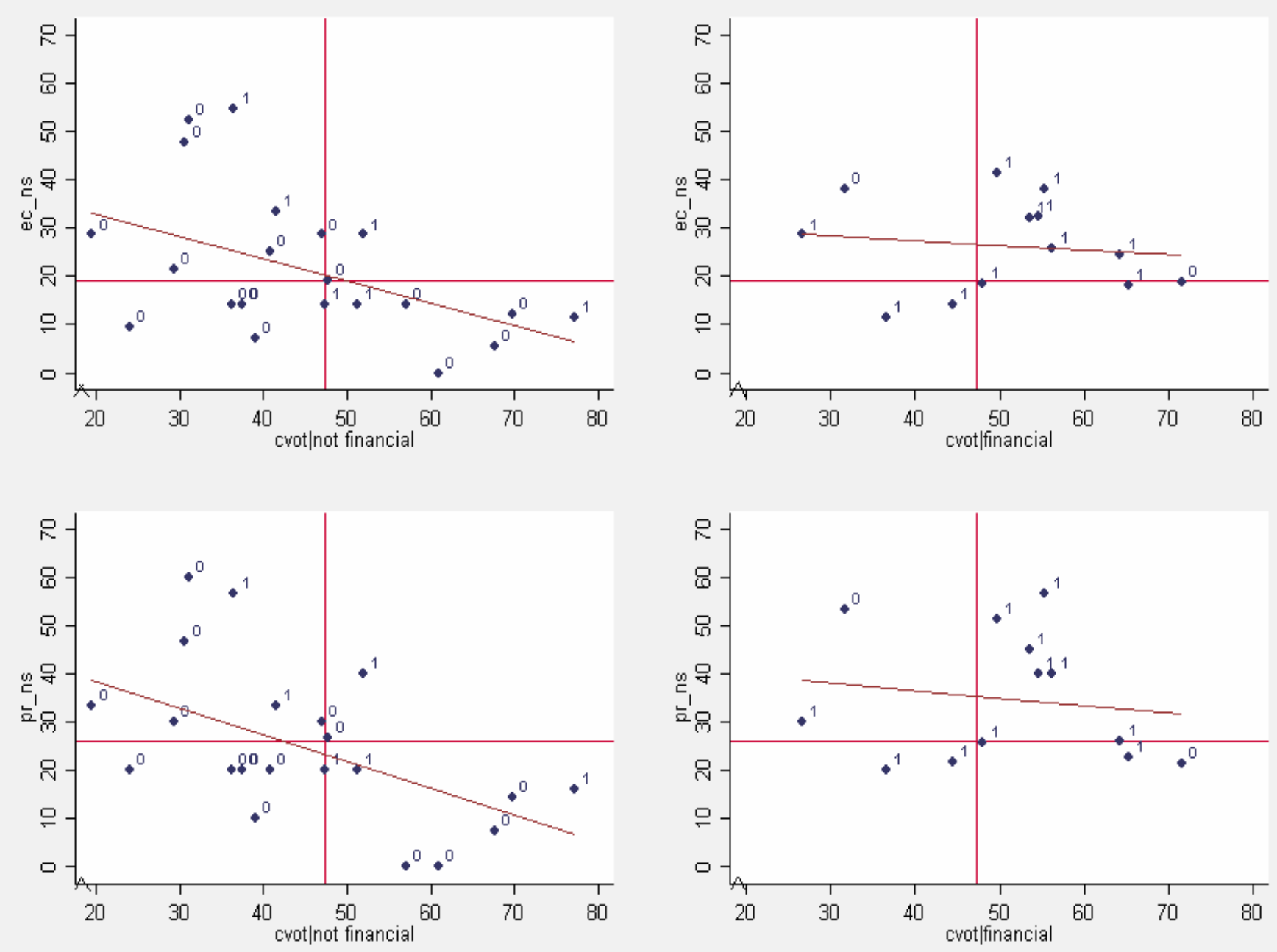
Table 18. Correlation matrices by company typology.

Not financial companies

\begin{tabular}{|c|c|c|c|c|c|c|c|c|}
\hline & ec_yes & pr_yes & ec_no & pr_no & ec_ns & pr_ns & cvot & c_net \\
\hline ec_yes & 1 & & & & & & & \\
\hline pr_yes & 0.81 & 1 & & & & & & \\
\hline ec_no & 0.28 & 0.53 & 1 & & & & & \\
\hline pr_no & 0.59 & 0.51 & 0.67 & 1 & & & & \\
\hline ec_ns & -0.91 & -0.86 & -0.65 & -0.75 & 1 & & & \\
\hline pr_ns & -0.82 & -0.92 & -0.67 & -0.81 & 0.94 & 1 & & \\
\hline Cvot & 0.47 & 0.56 & 0.21 & 0.32 & -0.46 & -0.53 & 1 & \\
\hline c_net & -0.31 & -0.21 & 0.1 & -0.23 & 0.2 & 0.25 & 0.27 & 1 \\
\hline
\end{tabular}

Financial companies

\begin{tabular}{|l|r|r|r|r|r|r|r|r|}
\hline & \multicolumn{1}{|c|}{ ec_yes } & \multicolumn{1}{c|}{ pr_yes } & \multicolumn{1}{c|}{ ec_no } & \multicolumn{1}{c|}{ pr_no } & \multicolumn{1}{c|}{ ec_ns } & \multicolumn{1}{c|}{ pr_ns } & \multicolumn{1}{c|}{ cvot } & c_net \\
\hline ec_yes & 1 & & & & & & & \\
\hline pr_yes & 0.77 & 1 & & & & & & \\
\hline ec_no & -0.04 & 0.36 & 1 & & & & & \\
\hline pr_no & 0.26 & 0.32 & 0.72 & 1 & & & & \\
\hline ec_ns & -0.66 & -0.82 & -0.69 & -0.71 & 1 & & & \\
\hline pr_ns & -0.71 & -0.91 & -0.59 & -0.68 & 0.94 & 1 & & \\
\hline Cvot & 0.05 & 0.04 & 0.13 & 0.29 & -0.13 & -0.15 & & 1 \\
\hline c_net & -0.3 & 0.03 & 0.44 & 0.14 & -0.1 & -0.08 & -0.04 & 1 \\
\hline
\end{tabular}

Cvot is the free float in 2003, source: Consob. C_net is a dummy variable that represents the participation to a cross-directorship network. Variables from ec_yes to pr_not represent our global rates. Cooperative Banks (banche popolari) are not considered due to the different shareholder voting rules (one-shareholder-one-vote). Missing value treatment: listwise deletion. 
Table 19. Free float data for 2003 and 2005

\begin{tabular}{|c|c|c|c|c|}
\hline Company & $2003(1)$ & $2005(2)$ & diff.(2)-(1) & perc. \\
\hline Alleanza Assicurazioni & 49.74 & 49.06 & -0.68 & -1.37 \\
\hline Assicurazioni Generali & 71.62 & 70.24 & -1.38 & -1.93 \\
\hline Autogrill & 40.77 & 36.18 & -4.59 & -11.26 \\
\hline Autostrade & 29.26 & 37.34 & 8.08 & 27.61 \\
\hline \multicolumn{5}{|l|}{ Banca Antonveneta } \\
\hline Banca Fideuram & 26.54 & 26.59 & 0.05 & 0.19 \\
\hline Banca Intesa & 48.04 & 55.91 & 7.87 & 16.38 \\
\hline Banca Monte dei Paschi di Siena & 36.51 & 32.73 & -3.78 & -10.35 \\
\hline Banca Popolare di Milano & 95.65 & 95.95 & 0.3 & 0.31 \\
\hline Banco Popolare di Verona e Novara & 92.12 & 93.19 & 1.07 & 1.16 \\
\hline Banche Popolari Unite & 100 & & & \\
\hline Benetton & 30.65 & 32.86 & 2.21 & 7.21 \\
\hline $\mathrm{BNL}$ & 54.58 & & & \\
\hline Bulgari & 31.12 & 38.82 & 7.7 & 24.74 \\
\hline Capitalia & 55.4 & 59.73 & 4.33 & 7.82 \\
\hline E.Biscom (Fastweb) & 47.27 & 63.72 & 16.45 & 34.8 \\
\hline Edison & 19.51 & 11.43 & -8.08 & -41.41 \\
\hline Enel & 39.02 & 67.78 & 28.76 & 73.71 \\
\hline ENI & \begin{tabular}{l|l}
69.68 \\
\end{tabular} & 69.68 & 0 & 0 \\
\hline Fiat & 60.85 & 48.23 & -12.62 & -20.74 \\
\hline Finmeccanica & 67.55 & 67.55 & 0 & $\overline{0}$ \\
\hline Fondiaria SAI & 64.33 & 62.49 & -1.84 & -2.86 \\
\hline Gruppo Editoriale l'Espresso & 36.47 & 33.22 & -3.25 & -8.91 \\
\hline Italcementi & 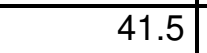 & 38.3 & -3.2 & -7.71 \\
\hline Luxottica & 23.96 & 26.48 & 2.52 & 10.52 \\
\hline Mediaset & 46.94 & 56.85 & 9.91 & 21.11 \\
\hline Mediobanca & 56.29 & 59.49 & 3.2 & 5.68 \\
\hline Mediolanum & 31.72 & 31.85 & 0.13 & 0.41 \\
\hline Mondadori & 47.73 & 47.76 & 0.03 & 0.06 \\
\hline Pirelli \& Co & 51.19 & 52.6 & 1.41 & 2.75 \\
\hline RAS & 44.45 & 19.46 & -24.99 & -56.22 \\
\hline RCS Mediagroup & 51.89 & 27.41 & -24.48 & -47.18 \\
\hline San Paolo IMI & \begin{tabular}{l|l}
53.58 \\
\end{tabular} & 58.23 & 4.65 & 8.68 \\
\hline Seat Pagine Gialle & 37.48 & 45.15 & 7.67 & 20.46 \\
\hline Snam Rete Gas & \begin{tabular}{l|l}
36.19 \\
\end{tabular} & 47.95 & 11.76 & 32.5 \\
\hline \multicolumn{5}{|l|}{ STMicroelectronics } \\
\hline Telecom Italia & 77.13 & 72.65 & -4.48 & -5.81 \\
\hline Telecom Italia Mobile & 37.5 & 30.78 & -6.72 & -17.92 \\
\hline Tiscali & 57.02 & 60.18 & 3.16 & 5.54 \\
\hline Unicredito & 65.27 & 69.11 & 3.84 & 5.88 \\
\hline
\end{tabular}

Source: Consob. The table represents the percentage of shareholders who hold less than $2 \%$ of total voting shares. All data are referred respectively to the 31.12.2003 and 31.12.2005. 
Table 20. Independent directors by company (2003)

\begin{tabular}{|c|c|c|}
\hline Company & \begin{tabular}{|l|} 
Independent directors 2003 \\
\end{tabular} & 50th perc. S\&P mib40 $=100$ \\
\hline Alleanza Assicurazioni & 9 & 164 \\
\hline Assicurazioni Generali & 13 & 236 \\
\hline Autogrill & 4 & 73 \\
\hline Autostrade & 4 & 73 \\
\hline Banca Antonveneta & 3 & 55 \\
\hline Banca Fideuram & 2 & 36 \\
\hline Banca Intesa & 7 & 127 \\
\hline Banca Monte dei Paschi di Siena & 16 & 291 \\
\hline Banca Popolare di Milano & 20 & 364 \\
\hline Banche Popolari Unite & 20 & 364 \\
\hline Banco Popolare di Verona e Novara & 19 & 345 \\
\hline Benetton & 3 & 55 \\
\hline $\mathrm{BNL}$ & 11 & 200 \\
\hline Bulgari & 3 & 55 \\
\hline Capitalia & 6 & 109 \\
\hline E.Biscom (Fastweb) & 2 & 36 \\
\hline Edison & 3 & 55 \\
\hline Enel & 6 & 109 \\
\hline ENI & 7 & 127 \\
\hline Fiat & 5 & 91 \\
\hline Finmeccanica & 8 & 145 \\
\hline Fondiaria SAI & 10 & 182 \\
\hline Gruppo Editoriale l'Espresso & 6 & 109 \\
\hline Italcementi & 6 & 109 \\
\hline Luxottica & 3 & 55 \\
\hline Mediaset & 4 & 73 \\
\hline Mediobanca & 5 & 91 \\
\hline Mediolanum & 3 & 55 \\
\hline Mondadori & 3 & 55 \\
\hline Pirelli \& Co & 7 & 127 \\
\hline RAS & 12 & 218 \\
\hline RCS Mediagroup & 3 & 55 \\
\hline San Paolo IMI & 12 & 218 \\
\hline Seat Pagine Gialle & 3 & 55 \\
\hline Snam Rete Gas & 2 & 36 \\
\hline STMicroelectronics & 7 & 127 \\
\hline Telecom Italia & 5 & 91 \\
\hline Telecom Italia Mobile & 5 & 91 \\
\hline Tiscali & 2 & 36 \\
\hline Unicredito & 15 & 273 \\
\hline 50th perc.S \& P MIB & 5.5 & 100 \\
\hline Sum S \& P MIB & 284 & \\
\hline
\end{tabular}

The table reports the number of independent directors and the relative performance with respect to the $50^{\text {th }}$ percentile of all the 40 S\&P-MIB companies of the population. 


\section{References}

- Anderson, R. C. and D. M. Reeb (2003). Who Monitors the Family? $\underline{\text { http://ssrn.com/abstract }=369620}$

- Assonime (2004). Handbook on Corporate Governance Reports, February, http://www.ecgi.org/codes/documents/cg_guide.pdf

- Assonime - Emittenti Titoli Spa (2005). Analisi dello stato di attuazione del Codice di Autodisciplina delle società quotate (Anno 2005), forthcoming in Assonime, Note e Studi, December.

- Barclay, M. and C. Holderness (1989). Private Benefits of Control of Public Corporations, Journal of Financial Economics, 371-395.

- Bebchuk, L. (1999). A Rent-Protection Theory of Corporate Ownership and Control, NBER working paper 7203.

- Bebchuk, L. and C. Jolls (1999). Managerial Value Diversion and Shareholder Wealth, Journal of Law, Economics and Organization, vol. (15) 2, p. 487-502.

- Becht; M., P. Bolton and A. Röell (2002). Corporate Governance and Control, October, www.ssrn.com

- Belcredi, M. (2005). Amministratori indipendenti, amministratori di minoranza, e dintorni, Rivista delle Società, n. 4/2005.

- Bhagat, S. and B. Black (1999). The Uncertain Relationship Between Board Composition and Firm Performance, Bus. Law Rev., vol. 54, p. 921.

- Bhagat, S. and B. Black (2001). The Non-Correlation Between Board Independence and Long-Term Firm Performance, Journal of Corporation Law, vol. 27, p. 231-274.

- Black, B. (2001). The Legal and Institutional Preconditions for Strong Securities Markets, 48 UCLA L. Rev., p. 781-810.

- Borgatti, S.P., Everett, M.G. and Freeman, L.C. (2002). Ucinet for Windows: Software for Social Network Analysis. Harvard, MA: Analytic Technologies.

- Brogi, R. and P. Santella (2005). Corporate Governance Ratings: Already on Display, Not for Sale Yet, mimeo.

- Bushman, R. M. and A. J. Smith (2001). Financial Accounting Information and Corporate Governance, Journal of Accounting and Economics, vol. 32, p. 237-334.

- Byrd, J. and K. Hickman (1992). Do Outside Directors Monitor Managers? Evidence from Tender Offer Bids, Journal of Financial Economics, vol. 32, p. 195222. 
- Cappiello, S. (2005). La remunerazione degli amministratori: "incentivi azionari" e creazione di valore, Milano, Giuffré.

- Caprio, G, Laeven, L and R. Levine (2006). Governance and Bank Valuation, http://www.econ.brown.edu/fac/Ross_Levine/Publication/Forthcoming/Forth_GC -LL-RL_Govn\%20\%\%20Valuation.pdf

- CEBS (2005). Guidelines on Supervisory Disclosure, 1 November, http://www.cebs.org/pdfs/GL05.pdf

- Cervone, E. (2004). L'evoluzione delle regole e della vigilanza nel contesto internazionale,

http://www.consob.it/main/documenti/Pubblicazioni/Audizioni/intervento_23102 004.html?hkeywords $=\&$ docid $=3 \&$ page $=0 \&$ hits $=51 \&$ nonewsearch $=1$

- Chandler III, W. B. (1999). On the Instructiveness of Insiders, Independents, and Institutional Investors, 67 U. Cin. L. Rev., p. 1083-4.

- Claessens, S., S. Djankov, and L. Lang (2000). The Separation of Ownership and Control in East Asian Corporations, Journal of Financial Economics, vol. 58, p. 21112.

- Cleveland W.S (1993) “Visualizing data” Hobart Press, Summit New Jersey USA.

- DeAngelo, H. and L. DeAngelo (1985). Managerial Ownership of Voting Rights, Journal of Financial Economics, vol. 14, p. 36-39.

- DeAngelo, H. and L. DeAngelo (2000). Controlling Stockholders and the Disciplinary Role of Corporate Payout Policy: A Study of the Times Mirror Company, Journal of Financial Economics, vol. 56, p. 153-207.

- De Cecco, M, and G. Ferri (1996). Le banche d'affari in Italia, Bologna, Il Mulino.

- Demsetz, H. (1983). The Structure of Ownership and the Theory of the Firm, Journal of Law and Economics, vol. 26, p. 375-390.

- Dyck, A. and L. Zingales (2004). Private Benefits of Control: An International Comparison, The Journal of Finance, vol. 59, p. 537-73.

- Eckbo, E. (2005). Strong Insiders Invite Weak Governance, Financial Times, May 19.

- European Commission (2005). Recommendation on the Role of Non-Executive or Supervisory Directors of Listed Companies and on the Committees of the (Supervisory) Board, February, http://europa.eu.int/eurlex/lex/LexUriServ/site/en/oj/2005/1_052/1_05220050225en00510063.pdf

- Everitt B.S, and G. Dunn (2000). Applied Multivariate Data Analysis, Oxford University Press. 
- Faccio, M. and L. P.H. Lang (2002). The Ultimate Ownership of Western European Corporations, Journal of Financial Economics, vol. 63: 365-95.

- Fama, E. and M. Jensen (1983). Separation of Ownership and Control, Journal of Law and Economics, vol. 26, p. 301-25.

- Fama, E. and M. Jensen (1985). Organizational Forms and Investment Decisions, Journal of Financial Economics, vol. 14, p. 101-119.

- Fich, E. M. and A. Shivdasani (2004). Are Busy Boards Effective Monitors? February, mimeo

- Financial Reporting Council (2006). Review of the 2003 Combined Code, January.

- Gordon, J. N. (2006). Independnet Directors and Stock Market Prices: The New Corporate Governance Paradigm, ECGI Law Working Paper N 74/2006.

- Grossman, S. and O. Hart (1980). Takeover bids, the free rider problem, and the theory of the corporation, Bell Journal of Economics, vol. 11, p. 42-69.

- Grossman, S. and O. Hart (1988). One Share One Vote and the Market for Corporate Control, Journal of Financial Economics, vol. 20(1-2), p. 175-202.

- Hanneman, R. A. and M. Riddle (2005). Introduction to social network methods. Riverside, CA: University of California, Riverside http:/ / faculty.ucr.edu/ hanneman/

- Hansmann, H. and R. Kraakman (2001). The End of History for Corporate Law, Georgetown Law Journal, vol. 89, p. 439-468.

- Hermalin, B. E. and M. S. Weisbach (1998). Endogeneously Chosen Boards of Directors and their Monitoring of the CEO, American Economic Review, vol. 88, p. 96-118.

- Hermalin, B. E. and M. S. Weisbach (2003). Boards of Directors as an Endogeneously Determined Institution: A Survey of the Economic Literature, Working Paper Series, paper 3, Centre for Responsible Business, University of California, Berkeley.

- Higgs, D. (2003). The Higgs Report: Review of the Role and Effectiveness of NonExecutive Directors, http://www.ecgi.org/codes/code.php?code_id=121

- Jensen, M. and W. M. Meckling (1976). The Theory of the Firm: Managerial Behavior, Agency Costs, and Ownership Structure, Journal of Financial Economics, vol. 3, p. 305-360.

- Klein, A. (1998). Firm Productivity and Board Committee Structure, Journal of Law and Economics, vol. 41, p. 137-165. 
- Kraakman, R. R., P. Davies, H. Hansmann, G. Hertig, K. J. Hopt, H. Kanda, and E. B. Rock (2004). The Anatomy of Corporate Law, A Comparative and Functional Approach, Oxford University Press, 2004.

- La Porta, R., F. Lopez-De-Silanes,, A. Shleifer, and R. W. Vishny (1997), Legal Determinants of External Finance, Journal of Finance, vol. 52, n. 3, p. 1131-1150.

- La Porta, R., F. Lopez-De-Silanes, A. Shleifer, and R. W. Vishny (1998). Law and Finance, Journal of Political Economy, vol. 106, n. 6, p. 1113-1155.

- Larcker, D. F., S. A. Richardson, and I. Tuna (2004). How Important is Corporate Governance? mimeo.

- Lease, Ronald C., John J. McConnell, and Wayne H. Mikkelson (1983). The Market Value of Control in Publicly-Traded Corporations. Journal of Financial Economics, vol. 11 (1-4), p. 439-71.

- Lease, Ronald C., John J. McConnell, and Wayne H. Mikkelson (1984). The Market Value of Differential Voting Rights in Closely Held Corporations, Journal of Business, vol. 57 (4), p. 443-67.

- Levine, R. (2004). "The Corporate Governance of Banks: A Concise Discussion of Concepts and Issues." in Global Corporate Governance Forum Washington, D.C. (www.gcgf.org) and The Certified Accountant, 18, April.

- Little R.J.A, Rubin D.B. (1987) Statistical analysis with missing data. New York, Wiley.

- Lorsch, J. and E. MacIver (1989). Pawns or Potentates: The Reality of America's Corporate Boards, Harvard Business School Press, Boston.

- MacAvoy, P.S. and M. Millstein (1999). The Active Board of Directors and Its Effects on the Performance of the Large Publicly Traded Corporation, Journal of Applied Corporate Finance, vol. 11(4), p. 8-20.

- Millstein, I. M. (1993). The Evolution of the Certifying Board, 48 Bus. Law, p. 1485.

- Modigliani, F. and E. Perotti (1998). Protection of Minority Interest and the Development of Security Markets, Managerial and Decision Economics, vol. 18, p. 519-528.

- Moody's (2003). US and Canadian Corporate Governance Assessment, July, mimeo.

- Moody's (2004). Moody's Findings on Corporate Governance in the United States and Canada: August - September, mimeo. 
- Nenova, T. (2003). The Value of Corporate Voting Rights and Control: A CrossCountry Analysis, Journal of Financial Economics, vol. 68, p. 325-351.

- OECD (2003). Survey of Corporate Governance Developments in OECD Countries, www.oecd.org

- OECD (2004). Principles of Corporate Governance, www.oecd.org

- Onado, M. (2005). Autodisciplinati per legge, www.lavoce.info

- Patel, S. A. and G. Dallas (2002). Transparency and Disclosure: Overview of Methodology and Study Results-United States.

- Penati, A. (2004a). La doppia età del capitalismo, La Repubblica, 11 September.

- Penati, A. (2004b). Non di sole regole vive il mercato, La Repubblica, 20 September.

- Peracchi, F. (2001). Econometrics, Wiley \& Sons.

- Pinza, R. and A. Zoppini (2004). Le regole per tutelare i risparmiatori, Il Sole 24 Ore, 22 October.

- Protiviti (2004). Gli amministratori indipendenti nelle quotate italiane. Il profilo attuale. http://www.protiviti.it/downloads/Doc2-Newsletter-n2-gennaio-2005.pdf

- R Development Core Team (2006). R: a language and Environment for Statistical Computing, $\mathrm{R}$ Foundation for Statistical Computing, Vienna (Austria). http://www.r-project.org/index.html

- $R$ Development Core Team (2006). R: language definition. http://www.rproject.org/

- Rajan, R. and L. Zingales (2004). Salvare il capitalismo dai capitalisti, Il Mulino.

- Roe, M. (2001). Rents and Their Corporate Law Consequences, discussion paper, Columbia Law School.

- Rosenstein, S. and J. Wyatt (1990). Outside Directors, Board Independence, and Shareholder Wealth, Journal of Financial Economics, vol. 26, p. 175-184.

- Rosenstein, S. and J. Wyatt (1997). Inside Directors, Board Effectiveness, and Shareholder Wealth, Journal of Financial Economics, vol. 44, p. 229-48.

- Rydqvist, K. (1987). Empirical Investigation of the Voting Premium, Northwestern University Working Paper No. 35.

- Santella, P. (2001). Banche cooperative o fondazioni bancarie? Un'analisi di corporate governance delle banche di credito cooperativo (A Corporate Governance Analysis of Italian Credit Unions); Bancaria, November. 
- Santella, P., Paone, G., and C. Drago (2005). How Independent Are Independent Directors? The Case of Italy, http://ssrn.com/abstract=839204

- Shleifer, A. and R. Vishny (1997). A Survey of Corporate Governance, Journal of Finance vol. 52, p. 737-783.

- Smith, A. (1776). An Inquiry into the Nature and Causes of the Wealth of Nations, reprinted by Oxford UP, 1998.

- Standard \& Poor's (2004). Corporate Governance Scores and Evaluations Criteria, Methodology and Definitions, January.

- StataCorp (2005). Stata Statistical Software: Release 9. College Station, TX: StataCorp LP

- StataCorp (2005) Programming Reference Manual, Stata Press

- Vella, F. (2005). Le cooperative e la finanza, www.lavoce.info

- Wassermann S., Faust K., Iacobucci D. (1994) Social Network Analysis: methods and applications, Cambridge University Press

- Weil, Gotshal \& Manges (2002). Comparative Matrix Of Corporate Governance Codes Relevant To The European Union And Its Member States, http:/ / europa.eu.int/comm/internal_market/company/docs /corpgov/corp-govcodes-rpt-part3_en.pdf

- Winter, Ralph (1977). State Law, Shareholder Protection, and the Theory of the Corporation, Journal of Legal Studies, vol. 6, p. 251-292.

- Zadra, G. European Banks cross-shareholdings right votes, mimeo

- Zingales, L. (1994). The Value of the Voting Right: A Study of the Milan Stock Exchange Experience, The Review of Financial Studies, vol. 7, p. 125-148.

- Zingales, L. (1995). What Determines the Value of Corporate Votes, The Quarterly Journal of Economics, vol. 110, p. 1047-1073 


\section{Appendix A: Company rates and Ranks according to each Preda and EC criterion}

Compliance rates by single criteria (Preda and EC)

\begin{tabular}{|c|c|c|c|c|c|c|c|c|c|}
\hline Company & $\begin{array}{l}\text { Bus.Rel. } \\
\text { (Preda) }\end{array}$ & $\begin{array}{l}\text { Shares } \\
\text { Owned } \\
\text { (Preda) }\end{array}$ & $\begin{array}{l}\text { Family } \\
\text { Ties } \\
\text { (EC\Preda) }\end{array}$ & $\begin{array}{l}\text { Profess. } \\
\text { Qualif. } \\
\text { (EC|Preda) }\end{array}$ & $\begin{array}{l}\text { Other } \\
\text { Comm. } \\
\text { (EC \Preda) }\end{array}$ & $\begin{array}{l}\text { Ec Bus. } \\
\text { Rel. Enl. } \\
\text { (EC) }\end{array}$ & $\begin{array}{l}\text { Addit. } \\
\text { Rem. } \\
\text { (EC) }\end{array}$ & $\begin{array}{l}\text { Cross Dir. } \\
\text { (EC) }\end{array}$ & $\begin{array}{l}\text { Perman } \\
\text { (EC) }\end{array}$ \\
\hline Alleanza Assicurazioni & 0 & 100 & 0 & 77.78 & 22.22 & 0 & 100 & 77.78 & 55.56 \\
\hline Assicurazioni Generali & 0 & 100 & 100 & 100 & 0 & 0 & 92.31 & 100 & 61.54 \\
\hline Autogrill & 0 & 100 & 100 & 100 & 0 & 0 & 100 & 100 & 25 \\
\hline Autostrade & 0 & 100 & 100 & 75 & 25 & 0 & 100 & 100 & 100 \\
\hline Banca Fideuram & 0 & 100 & 100 & 100 & 0 & 0 & 100 & 100 & 0 \\
\hline Banca Intesa & 0 & 100 & 100 & 71.43 & 28.57 & 0 & 85.71 & 100 & 71.43 \\
\hline Banca Monte dei Paschi di Siena & 0 & 93.75 & 100 & 100 & 0 & 0 & 68.75 & 81.25 & 68.75 \\
\hline Banca Popolare di Milano & 0 & 100 & 100 & 100 & 20 & 0 & 80 & 100 & 75 \\
\hline Banche Popolari Unite & 0 & 100 & 100 & 100 & 0 & 0 & 45 & 90 & 0 \\
\hline Bulgari & 0 & 100 & 0 & 33.33 & 66.67 & 0 & 100 & 100 & 33.33 \\
\hline Capitalia & 0 & 100 & 0 & 83.33 & 16.67 & 0 & 100 & 83.33 & 83.33 \\
\hline E.Biscom (Fastweb) & 0 & 100 & 100 & 100 & 0 & 0 & 100 & 100 & 100 \\
\hline Edison & 33.33 & 100 & 0 & 100 & 0 & 33.33 & 100 & 100 & 66.67 \\
\hline Enel & 16.67 & 100 & 100 & 100 & 50 & 16.67 & 83.33 & 100 & 100 \\
\hline ENI & 14.29 & 100 & 100 & 100 & 42.86 & 14.29 & 85.71 & 100 & 71.43 \\
\hline Fiat & 40 & 100 & 100 & 100 & 20 & 40 & 100 & 100 & 100 \\
\hline Finmeccanica & 12.5 & 100 & 100 & 100 & 25 & 12.5 & 100 & 100 & 100 \\
\hline Fondiaria SAI & 0 & 100 & 100 & 90 & 10 & 0 & 90 & 70 & 60 \\
\hline Gruppo Editoriale l'Espresso & 0 & 100 & 0 & 50 & 50 & 0 & 100 & 83.33 & $\overline{0}$ \\
\hline RAS & 0 & 100 & 100 & 91.67 & 8.33 & 0 & 91.67 & 75 & 58.33 \\
\hline RCS Mediagroup & 0 & 100 & 0 & 100 & 0 & 0 & 100 & 100 & 100 \\
\hline San Paolo IMI & 0 & 100 & 0 & 75 & 33.33 & 0 & 25 & 75 & 75 \\
\hline Seat Pagine Gialle & 0 & 100 & 100 & 100 & 0 & 0 & 100 & 100 & 100 \\
\hline Snam Rete Gas & 0 & 100 & 100 & 100 & 0 & 0 & 100 & 100 & 100 \\
\hline STMicroelectronics & 14.29 & 100 & 0 & 100 & 28.57 & 14.29 & 14.29 & 100 & 57.14 \\
\hline Telecom Italia & 20 & 100 & 100 & 100 & 20 & 20 & 100 & 80 & 100 \\
\hline Telecom Italia Mobile & 0 & 100 & 100 & 100 & 0 & 0 & 100 & 100 & 100 \\
\hline Tiscali & 50 & 100 & 100 & 100 & 0 & 50 & 0 & 100 & 100 \\
\hline Unicredito & 0 & 100 & 100 & 86.67 & 13.33 & 0 & 66.67 & 73.33 & 80 \\
\hline
\end{tabular}


Business Relationships (Preda)

\begin{tabular}{|c|c|c|c|c|}
\hline Rank & Company & rate_yes & $\max \mathrm{S} \& \mathrm{P}$ mib=100 & Group \\
\hline 1 & Tiscali & 50 & 100 & 1 \\
\hline 2 & Fiat & 40 & 80 & 1 \\
\hline 3 & Edison & 33.33 & 67 & $\overline{1}$ \\
\hline 4 & Telecom Italia & 20 & 40 & 1 \\
\hline 5 & Enel & 16.67 & 33 & 1 \\
\hline 6 & ENI & 14.29 & 29 & 1 \\
\hline 6 & STMicroelectronics & 14.29 & 29 & 1 \\
\hline 8 & Finmeccanica & 12.5 & 25 & 1 \\
\hline 9 & Alleanza Assicurazioni & 0 & 0 & 1 \\
\hline 9 & Assicurazioni Generali & 0 & 0 & 1 \\
\hline 9 & Autogrill & 0 & 0 & 1 \\
\hline 9 & Autostrade & 0 & 0 & 1 \\
\hline 9 & Banca Antonveneta & 0 & 0 & 1 \\
\hline 9 & Banca Fideuram & 0 & 0 & 1 \\
\hline 9 & Banca Intesa & 0 & 0 & 1 \\
\hline 9 & Banca Monte dei Paschi di Siena & 0 & 0 & 1 \\
\hline 9 & Banca Popolare di Milano & 0 & 0 & 1 \\
\hline 9 & Banche Popolari Unite & 0 & 0 & 1 \\
\hline 9 & Banco Popolare di Verona e Novara & 0 & 0 & 1 \\
\hline 9 & Benetton & 0 & 0 & 1 \\
\hline 9 & BNL & 0 & 0 & 1 \\
\hline 9 & Bulgari & 0 & 0 & 1 \\
\hline 9 & Capitalia & 0 & 0 & 1 \\
\hline 9 & E.Biscom (Fastweb) & 0 & 0 & 1 \\
\hline 9 & Fondiaria SAI & 0 & 0 & 1 \\
\hline 9 & Gruppo Editoriale l'Espresso & 0 & 0 & 1 \\
\hline 9 & Italcementi & 0 & $\overline{0}$ & $\overline{1}$ \\
\hline 9 & Luxottica & 0 & 0 & 1 \\
\hline 9 & Mediaset & 0 & 0 & 1 \\
\hline 9 & Mediobanca & 0 & 0 & 1 \\
\hline 9 & Mediolanum & 0 & 0 & 1 \\
\hline 9 & Mondatori & 0 & 0 & 1 \\
\hline 9 & Pirelli \& Co & 0 & 0 & 1 \\
\hline 9 & RAS & 0 & 0 & 1 \\
\hline 9 & RCS Mediagroup & 0 & 0 & 1 \\
\hline 9 & San Paolo IMI & 0 & 0 & 1 \\
\hline 9 & Seat Pagine Gialle & 0 & 0 & 1 \\
\hline 9 & Snam Rete Gas & 0 & 0 & 1 \\
\hline 9 & Telecom Italia Mobile & 0 & 0 & 1 \\
\hline 9 & Unicredito & 0 & 0 & 1 \\
\hline
\end{tabular}


Shares Owned (Preda)

\begin{tabular}{|c|c|c|c|c|}
\hline Rank & Company & rate_yes & $\max \mathrm{S} \& \mathrm{P}$ mib $=100$ & Group \\
\hline 1 & Alleanza Assicurazioni & 100 & 100 & 1 \\
\hline 1 & Assicurazioni Generali & 100 & 100 & 1 \\
\hline 1 & Autogrill & 100 & 100 & 1 \\
\hline 1 & Autostrade & 100 & 100 & 1 \\
\hline 1 & Banca Antonveneta & 100 & 100 & 1 \\
\hline 1 & Banca Fideuram & 100 & 100 & 1 \\
\hline 1 & Banca Intesa & 100 & 100 & 1 \\
\hline 1 & Banca Popolare di Milano & 100 & 100 & 1 \\
\hline 1 & Banche Popolari Unite & 100 & 100 & 1 \\
\hline 1 & Banco Popolare di Verona e Novara & 100 & 100 & 1 \\
\hline 1 & Benetton & 100 & 100 & 1 \\
\hline 1 & Bulgari & 100 & 100 & 1 \\
\hline 1 & Capitalia & 100 & 100 & 1 \\
\hline 1 & E.Biscom (Fastweb) & 100 & 100 & $\overline{1}$ \\
\hline 1 & Edison & 100 & 100 & 1 \\
\hline 1 & Enel & 100 & 100 & 1 \\
\hline 1 & ENI & 100 & 100 & 1 \\
\hline 1 & Fiat & 100 & 100 & 1 \\
\hline 1 & Finmeccanica & 100 & 100 & 1 \\
\hline 1 & Fondiaria SAI & 100 & 100 & 1 \\
\hline 1 & Gruppo Editoriale I'Espresso & 100 & 100 & 1 \\
\hline 1 & Italcementi & 100 & 100 & 1 \\
\hline 1 & Luxottica & 100 & 100 & 1 \\
\hline 1 & Mediaset & 100 & 100 & 1 \\
\hline 1 & Mediobanca & 100 & 100 & 1 \\
\hline 1 & Mediolanum & 100 & 100 & 1 \\
\hline 1 & Mondatori & 100 & 100 & 1 \\
\hline 1 & Pirelli \& Co & 100 & 100 & 1 \\
\hline 1 & RAS & 100 & 100 & 1 \\
\hline 1 & RCS Mediagroup & 100 & 100 & 1 \\
\hline 1 & San Paolo IMI & 100 & 100 & 1 \\
\hline 1 & Seat Pagine Gialle & 100 & 100 & 1 \\
\hline 1 & Snam Rete Gas & 100 & 100 & 1 \\
\hline 1 & STMicroelectronics & 100 & 100 & 1 \\
\hline 1 & Telecom Italia & 100 & 100 & 1 \\
\hline 1 & Telecom Italia Mobile & 100 & 100 & 1 \\
\hline 1 & Tiscali & 100 & 100 & 1 \\
\hline 1 & Unicredito & 100 & 100 & 1 \\
\hline 39 & Banca Monte dei Paschi di Siena & 93.75 & 94 & 4 \\
\hline 40 & BNL & 90.91 & 91 & 4 \\
\hline
\end{tabular}


Family Ties (Preda and EC)

\begin{tabular}{|c|c|c|c|c|}
\hline Rank & Company & rate_yes & $\max S \& P$ mib $=100$ & Group \\
\hline 1 & Assicurazioni Generali & 100 & 100 & 1 \\
\hline 1 & Autogrill & 100 & 100 & 1 \\
\hline 1 & Autostrade & 100 & 100 & 1 \\
\hline 1 & Banca Antonveneta & 100 & 100 & 1 \\
\hline 1 & Banca Fideuram & 100 & 100 & 1 \\
\hline 1 & Banca Intesa & 100 & 100 & 1 \\
\hline 1 & Banca Monte dei Paschi di Siena & 100 & 100 & 1 \\
\hline 1 & Banca Popolare di Milano & 100 & 100 & 1 \\
\hline 1 & Banche Popolari Unite & 100 & 100 & 1 \\
\hline 1 & Banco Popolare di Verona e Novara & 100 & 100 & 1 \\
\hline 1 & E.Biscom (Fastweb) & 100 & 100 & 1 \\
\hline 1 & Enel & 100 & 100 & 1 \\
\hline 1 & ENI & 100 & 100 & 1 \\
\hline 1 & Fiat & 100 & 100 & 1 \\
\hline 1 & Finmeccanica & 100 & 100 & 1 \\
\hline 1 & Fondiaria SAI & 100 & 100 & 1 \\
\hline 1 & Italcementi & 100 & 100 & 1 \\
\hline 1 & Luxottica & 100 & 100 & 1 \\
\hline 1 & Mediaset & 100 & 100 & 1 \\
\hline 1 & Mondatori & 100 & 100 & 1 \\
\hline 1 & Pirelli \& Co & 100 & 100 & 1 \\
\hline 1 & RAS & 100 & 100 & 1 \\
\hline 1 & Seat Pagine Gialle & 100 & 100 & 1 \\
\hline 1 & Snam Rete Gas & 100 & 100 & 1 \\
\hline 1 & Telecom Italia & 100 & 100 & 1 \\
\hline 1 & Telecom Italia Mobile & 100 & 100 & 1 \\
\hline 1 & Tiscali & 100 & 100 & 1 \\
\hline 1 & Unicredito & 100 & 100 & 1 \\
\hline 29 & Alleanza Assicurazioni & 0 & 0 & 3 \\
\hline 29 & Benetton & 0 & 0 & 3 \\
\hline 29 & BNL & 0 & 0 & 3 \\
\hline 29 & Bulgari & 0 & 0 & 3 \\
\hline 29 & Capitalia & 0 & 0 & 3 \\
\hline 29 & Edison & 0 & 0 & 3 \\
\hline 29 & Gruppo Editoriale l'Espresso & 0 & 0 & 3 \\
\hline 29 & Mediobanca & 0 & 0 & 3 \\
\hline 29 & Mediolanum & 0 & 0 & 3 \\
\hline 29 & RCS Mediagroup & 0 & 0 & 3 \\
\hline 29 & San Paolo IMI & 0 & 0 & 3 \\
\hline 29 & STMicroelectronics & 0 & 0 & 3 \\
\hline
\end{tabular}


Professional Qualification (Preda and EC)

\begin{tabular}{|c|c|c|c|c|}
\hline Rank & Company & rate_yes & $\max \mathrm{S} \& \mathrm{P}$ mib $=100$ & Group \\
\hline 1 & Assicurazioni Generali & 100 & 100 & 1 \\
\hline 1 & Autogrill & 100 & 100 & 1 \\
\hline 1 & Banca Fideuram & 100 & 100 & 1 \\
\hline 1 & Banca Monte dei Paschi di Siena & 100 & 100 & 1 \\
\hline 1 & Banca Popolare di Milano & 100 & 100 & 1 \\
\hline 1 & Banche Popolari Unite & 100 & 100 & 1 \\
\hline 1 & Banco Popolare di Verona e Novara & 100 & 100 & 1 \\
\hline 1 & Benetton & 100 & 100 & 1 \\
\hline 1 & BNL & 100 & 100 & 1 \\
\hline 1 & E.Biscom (Fastweb) & 100 & 100 & 1 \\
\hline 1 & Edison & 100 & 100 & 1 \\
\hline 1 & Enel & 100 & 100 & 1 \\
\hline 1 & ENI & 100 & 100 & 1 \\
\hline 1 & Fiat & 100 & 100 & 1 \\
\hline 1 & Finmeccanica & 100 & 100 & 1 \\
\hline 1 & Luxottica & 100 & 100 & 1 \\
\hline 1 & Pirelli \& Co & 100 & 100 & 1 \\
\hline 1 & RCS Mediagroup & 100 & 100 & 1 \\
\hline 1 & Seat Pagine Gialle & 100 & 100 & 1 \\
\hline 1 & Snam Rete Gas & 100 & 100 & 1 \\
\hline 1 & STMicroelectronics & 100 & 100 & 1 \\
\hline 1 & Telecom Italia & 100 & 100 & 1 \\
\hline 1 & Telecom Italia Mobile & 100 & 100 & 1 \\
\hline 1 & Tiscali & 100 & 100 & 1 \\
\hline 25 & RAS & 91.67 & 92 & 3 \\
\hline 26 & Fondiaria SAI & 90 & 90 & 3 \\
\hline 27 & Unicredito & 86.67 & 87 & 3 \\
\hline 28 & Capitalia & 83.33 & 83 & 3 \\
\hline 28 & Italcementi & 83.33 & 83 & 3 \\
\hline 30 & Mediobanca & 80 & 80 & 3 \\
\hline 31 & Alleanza Assicurazioni & 77.78 & 78 & 4 \\
\hline 32 & Autostrade & 75 & 75 & 4 \\
\hline 32 & San Paolo IMI & 75 & 75 & 4 \\
\hline 34 & Banca Intesa & 71.43 & 71 & 4 \\
\hline 35 & Banca Antonveneta & 66.67 & 67 & 4 \\
\hline 35 & Mondatori & 66.67 & 67 & 4 \\
\hline 37 & Gruppo Editoriale l'Espresso & 50 & 50 & 4 \\
\hline 37 & Mediaset & 50 & 50 & 4 \\
\hline 39 & Bulgari & 33.33 & 33 & 4 \\
\hline 39 & Mediolanum & 33.33 & 33 & 4 \\
\hline
\end{tabular}


Other Committments (Preda and EC)

\begin{tabular}{|c|c|c|c|c|}
\hline Rank & Company & rate_yes & $\max \mathrm{S} \& \mathrm{P}$ mib $=100$ & Group \\
\hline 1 & Bulgari & 66.67 & 100 & 1 \\
\hline 1 & Mediolanum & 66.67 & 100 & 1 \\
\hline 3 & Enel & 50 & 75 & 1 \\
\hline 3 & Gruppo Editoriale I'Espresso & 50 & 75 & 1 \\
\hline 3 & Mediaset & 50 & 75 & 1 \\
\hline 6 & ENI & $\overline{42.86}$ & 64 & 1 \\
\hline 7 & Banca Antonveneta & 33.33 & 50 & 1 \\
\hline 7 & Mondatori & 33.33 & 50 & 1 \\
\hline 7 & San Paolo IMI & 33.33 & 50 & 1 \\
\hline 10 & Banca Intesa & 28.57 & 43 & 1 \\
\hline 10 & STMicroelectronics & 28.57 & 43 & 1 \\
\hline 12 & Autostrade & 25 & 37 & 2 \\
\hline 12 & Finmeccanica & 25 & 37 & 2 \\
\hline 14 & Alleanza Assicurazioni & 22.22 & 33 & 2 \\
\hline 15 & Banca Popolare di Milano & 20 & 30 & 2 \\
\hline 15 & Fiat & 20 & 30 & 2 \\
\hline 15 & Mediobanca & 20 & 30 & 2 \\
\hline 15 & Telecom Italia & 20 & 30 & 2 \\
\hline 19 & Capitalia & 16.67 & 25 & 2 \\
\hline 19 & Italcementi & 16.67 & 25 & 2 \\
\hline 21 & Banco Popolare di Verona e Novara & 15.79 & 24 & 3 \\
\hline 22 & Pirelli \& Co & 14.29 & 21 & 3 \\
\hline 23 & Unicredito & 13.33 & 20 & 3 \\
\hline 24 & Fondiaria SAI & 10 & 15 & 3 \\
\hline 25 & RAS & 8.33 & 12 & 3 \\
\hline 26 & Assicurazioni Generali & 0 & 0 & 3 \\
\hline 26 & Autogrill & 0 & 0 & 3 \\
\hline 26 & Banca Fideuram & 0 & 0 & 3 \\
\hline 26 & Banca Monte dei Paschi di Siena & 0 & 0 & 3 \\
\hline 26 & Banche Popolari Unite & 0 & 0 & 3 \\
\hline 26 & Benetton & 0 & 0 & 3 \\
\hline 26 & BNL & 0 & 0 & 3 \\
\hline 26 & E.Biscom (Fastweb) & 0 & 0 & 3 \\
\hline 26 & Edison & 0 & 0 & 3 \\
\hline 26 & Luxottica & 0 & 0 & 3 \\
\hline 26 & RCS Mediagroup & 0 & 0 & 3 \\
\hline 26 & Seat Pagine Gialle & 0 & 0 & 3 \\
\hline 26 & Snam Rete Gas & 0 & 0 & 3 \\
\hline 26 & Telecom Italia Mobile & 0 & 0 & 3 \\
\hline 26 & Tiscali & 0 & 0 & 3 \\
\hline
\end{tabular}


Business relationships enlarged (EC)

\begin{tabular}{|c|c|c|c|c|}
\hline Rank & Company & rate_yes & $\max \mathrm{S} \& \mathrm{P}$ mib $=100$ & Group \\
\hline 1 & Tiscali & 50 & 100 & 1 \\
\hline 2 & Fiat & 40 & 80 & 1 \\
\hline 3 & Edison & 33.33 & 67 & 1 \\
\hline 4 & Telecom Italia & 20 & 40 & 1 \\
\hline 5 & Enel & 16.67 & 33 & 1 \\
\hline 6 & ENI & 14.29 & 29 & 1 \\
\hline 6 & STMicroelectronics & 14.29 & 29 & 1 \\
\hline 8 & Finmeccanica & 12.5 & 25 & 1 \\
\hline 9 & Alleanza Assicurazioni & 0 & 0 & 1 \\
\hline 9 & Assicurazioni Generali & 0 & 0 & 1 \\
\hline 9 & Autogrill & 0 & 0 & 1 \\
\hline 9 & Autostrade & 0 & 0 & 1 \\
\hline 9 & Banca Antonveneta & 0 & 0 & 1 \\
\hline 9 & Banca Fideuram & 0 & 0 & 1 \\
\hline 9 & Banca Intesa & 0 & 0 & 1 \\
\hline 9 & Banca Monte dei Paschi di Siena & 0 & 0 & 1 \\
\hline 9 & Banca Popolare di Milano & 0 & 0 & 1 \\
\hline 9 & Banche Popolari Unite & 0 & 0 & 1 \\
\hline 9 & Banco Popolare di Verona e Novara & 0 & 0 & 1 \\
\hline 9 & Benetton & 0 & 0 & 1 \\
\hline 9 & BNL & 0 & 0 & 1 \\
\hline 9 & Bulgari & 0 & 0 & 1 \\
\hline 9 & Capitalia & 0 & 0 & 1 \\
\hline 9 & E.Biscom (Fastweb) & 0 & 0 & 1 \\
\hline 9 & Fondiaria SAI & 0 & 0 & 1 \\
\hline 9 & Gruppo Editoriale l'Espresso & 0 & 0 & 1 \\
\hline 9 & Italcementi & 0 & 0 & 1 \\
\hline 9 & Luxottica & 0 & 0 & 1 \\
\hline 9 & Mediaset & 0 & 0 & 1 \\
\hline 9 & Mediobanca & 0 & 0 & 1 \\
\hline 9 & Mediolanum & 0 & 0 & 1 \\
\hline 9 & Mondatori & 0 & 0 & 1 \\
\hline 9 & Pirelli \& Co & 0 & 0 & 1 \\
\hline 9 & RAS & 0 & 0 & 1 \\
\hline 9 & RCS Mediagroup & 0 & 0 & 1 \\
\hline 9 & San Paolo IMI & 0 & 0 & 1 \\
\hline 9 & Seat Pagine Gialle & 0 & 0 & 1 \\
\hline 9 & Snam Rete Gas & 0 & 0 & 1 \\
\hline 9 & Telecom Italia Mobile & 0 & 0 & 1 \\
\hline 9 & Unicredito & 0 & 0 & 1 \\
\hline
\end{tabular}


Additional Remuneration (EC)

\begin{tabular}{|c|c|c|c|c|}
\hline Rank & Company & rate_yes & $\max \mathrm{S} \& \mathrm{P}$ mib $=100$ & Group \\
\hline 1 & Alleanza Assicurazioni & 100 & 100 & 1 \\
\hline 1 & Autogrill & 100 & 100 & $\overline{1}$ \\
\hline 1 & Autostrade & 100 & 100 & 1 \\
\hline 1 & Banca Fideuram & 100 & 100 & 1 \\
\hline 1 & BNL & 100 & 100 & $\overline{1}$ \\
\hline 1 & Bulgari & 100 & 100 & $\overline{1}$ \\
\hline 1 & Capitalia & 100 & 100 & 1 \\
\hline 1 & E.Biscom (Fastweb) & 100 & 100 & 1 \\
\hline 1 & Edison & 100 & 100 & 1 \\
\hline 1 & Fiat & 100 & 100 & 1 \\
\hline 1 & Finmeccanica & 100 & 100 & 1 \\
\hline 1 & Gruppo Editoriale l'Espresso & 100 & 100 & 1 \\
\hline 1 & Luxottica & 100 & 100 & 1 \\
\hline 1 & Mediaset & 100 & 100 & 1 \\
\hline 1 & Mediobanca & 100 & 100 & 1 \\
\hline 1 & Mediolanum & 100 & 100 & 1 \\
\hline 1 & Mondatori & 100 & 100 & $\overline{1}$ \\
\hline 1 & Pirelli \& Co & 100 & 100 & 1 \\
\hline 1 & RCS Mediagroup & 100 & 100 & 1 \\
\hline 1 & Seat Pagine Gialle & 100 & 100 & 1 \\
\hline 1 & Snam Rete Gas & 100 & 100 & 1 \\
\hline 1 & Telecom Italia & 100 & 100 & 1 \\
\hline 1 & Telecom Italia Mobile & 100 & 100 & 1 \\
\hline 24 & Assicurazioni Generali & 92.31 & 92 & 3 \\
\hline 25 & RAS & 91.67 & 92 & 3 \\
\hline 26 & Fondiaria SAI & 90 & 90 & 3 \\
\hline 27 & Banca Intesa & 85.71 & 86 & 3 \\
\hline 27 & ENI & 85.71 & 86 & 3 \\
\hline 29 & Enel & 83.33 & 83 & 3 \\
\hline 30 & Banca Popolare di Milano & 80 & 80 & 3 \\
\hline 31 & Banca Monte dei Paschi di Siena & 68.75 & 69 & 4 \\
\hline 32 & Banca Antonveneta & 66.67 & 67 & 4 \\
\hline 32 & Unicredito & 66.67 & 67 & 4 \\
\hline 34 & Banche Popolari Unite & 45 & 45 & 4 \\
\hline 35 & San Paolo IMI & 25 & 25 & 4 \\
\hline 36 & STMicroelectronics & 14.29 & 14 & 4 \\
\hline 37 & Banco Popolare di Verona e Novara & 0 & 0 & 4 \\
\hline 37 & Benetton & 0 & 0 & 4 \\
\hline 37 & Italcementi & 0 & 0 & 4 \\
\hline 37 & Tiscali & 0 & 0 & 4 \\
\hline
\end{tabular}


Cross Directorships (EC)

\begin{tabular}{|c|c|c|c|c|}
\hline Rank & Company & rate_yes & max S\&P mib=100 & Group \\
\hline 1 & Assicurazioni Generali & 100 & 100 & 1 \\
\hline 1 & Autogrill & 100 & 100 & 1 \\
\hline 1 & Autostrade & 100 & 100 & $\overline{1}$ \\
\hline 1 & Banca Antonveneta & 100 & 100 & 1 \\
\hline 1 & Banca Fideuram & 100 & 100 & 1 \\
\hline 1 & Banca Intesa & 100 & 100 & 1 \\
\hline 1 & Banca Popolare di Milano & 100 & 100 & 1 \\
\hline 1 & Benetton & 100 & 100 & 1 \\
\hline 1 & Bulgari & 100 & 100 & 1 \\
\hline 1 & E.Biscom (Fastweb) & 100 & 100 & 1 \\
\hline 1 & Edison & 100 & 100 & 1 \\
\hline 1 & Enel & 100 & 100 & 1 \\
\hline 1 & ENI & 100 & 100 & 1 \\
\hline 1 & Fiat & 100 & 100 & 1 \\
\hline 1 & Finmeccanica & 100 & 100 & 1 \\
\hline 1 & Luxottica & 100 & 100 & 1 \\
\hline 1 & Mediaset & 100 & 100 & 1 \\
\hline 1 & Mediolanum & 100 & 100 & $\overline{1}$ \\
\hline 1 & Mondatori & 100 & 100 & 1 \\
\hline 1 & RCS Mediagroup & 100 & 100 & 1 \\
\hline 1 & Seat Pagine Gialle & 100 & 100 & 1 \\
\hline 1 & Snam Rete Gas & 100 & 100 & 1 \\
\hline 1 & STMicroelectronics & 100 & 100 & 1 \\
\hline 1 & Telecom Italia Mobile & 100 & 100 & 1 \\
\hline 1 & Tiscali & 100 & 100 & 1 \\
\hline 26 & $\mathrm{BNL}$ & 90.91 & 91 & 3 \\
\hline 27 & Banche Popolari Unite & 90 & 90 & 3 \\
\hline 28 & Capitalia & 83.33 & 83 & 3 \\
\hline 28 & Gruppo Editoriale I'Espresso & 83.33 & 83 & 3 \\
\hline 28 & Italcementi & 83.33 & 83 & 3 \\
\hline 31 & Banca Monte dei Paschi di Siena & 81.25 & 81 & 4 \\
\hline 32 & Mediobanca & 80 & 80 & 4 \\
\hline 32 & Telecom Italia & 80 & 80 & 4 \\
\hline 34 & Banco Popolare di Verona e Novara & 78.95 & 79 & 4 \\
\hline 35 & Alleanza Assicurazioni & 77.78 & 78 & 4 \\
\hline 36 & RAS & 75 & 75 & 4 \\
\hline 36 & San Paolo IMI & 75 & 75 & 4 \\
\hline 38 & Unicredito & 73.33 & 73 & 4 \\
\hline 39 & Pirelli \& Co & 71.43 & 71 & 4 \\
\hline 40 & Fondiaria SAI & 70 & 70 & 4 \\
\hline
\end{tabular}


Permanence on the Board (EC)

\begin{tabular}{|c|c|c|c|c|}
\hline Rank & Company & rate_yes & $\max \mathrm{S} \& \mathrm{P}$ mib=100 & Group \\
\hline 1 & Autostrade & 100 & 100 & 1 \\
\hline 1 & Banca Antonveneta & 100 & 100 & 1 \\
\hline 1 & Benetton & 100 & 100 & $\overline{1}$ \\
\hline 1 & E.Biscom (Fastweb) & 100 & 100 & 1 \\
\hline 1 & Enel & 100 & 100 & 1 \\
\hline 1 & Fiat & 100 & 100 & 1 \\
\hline 1 & Finmeccanica & 100 & 100 & 1 \\
\hline 1 & Mediobanca & 100 & 100 & 1 \\
\hline 1 & Mediolanum & 100 & 100 & 1 \\
\hline 1 & Mondatori & 100 & 100 & 1 \\
\hline 1 & RCS Mediagroup & 100 & 100 & 1 \\
\hline 1 & Seat Pagine Gialle & 100 & 100 & 1 \\
\hline 1 & Snam Rete Gas & 100 & 100 & 1 \\
\hline 1 & Telecom Italia & 100 & 100 & 1 \\
\hline 1 & Telecom Italia Mobile & 100 & 100 & 1 \\
\hline 1 & Tiscali & 100 & 100 & 1 \\
\hline 17 & Capitalia & 83.33 & 83 & 2 \\
\hline 18 & Unicredito & 80 & 80 & 2 \\
\hline 19 & Banca Popolare di Milano & 75 & 75 & 2 \\
\hline 19 & San Paolo IMI & 75 & 75 & 2 \\
\hline 21 & Banca Intesa & 71.43 & 71 & 3 \\
\hline 21 & ENI & 71.43 & 71 & 3 \\
\hline 23 & Banca Monte dei Paschi di Siena & 68.75 & 69 & 3 \\
\hline 24 & Edison & 66.67 & 67 & 3 \\
\hline 25 & BNL & 63.64 & 64 & 3 \\
\hline 26 & Assicurazioni Generali & 61.54 & 62 & 3 \\
\hline 27 & Fondiaria SAI & 60 & 60 & 3 \\
\hline 28 & RAS & 58.33 & 58 & 3 \\
\hline 29 & Pirelli \& Co & 57.14 & 57 & 3 \\
\hline 29 & STMicroelectronics & 57.14 & 57 & 3 \\
\hline 31 & Alleanza Assicurazioni & 55.56 & 56 & 4 \\
\hline 32 & Mediaset & 50 & 50 & 4 \\
\hline 33 & Banco Popolare di Verona e Novara & 36.84 & 37 & 4 \\
\hline 34 & Bulgari & 33.33 & 33 & 4 \\
\hline 34 & Italcementi & $\overline{33.33}$ & 33 & 4 \\
\hline 34 & Luxottica & 33.33 & 33 & 4 \\
\hline 37 & Autogrill & 25 & 25 & 4 \\
\hline 38 & Banca Fideuram & 0 & 0 & 4 \\
\hline 38 & Banche Popolari Unite & 0 & 0 & 4 \\
\hline 38 & Gruppo Editoriale l'Espresso & 0 & 0 & 4 \\
\hline
\end{tabular}

